ANA LUIZA MASSENA FERREIRA 

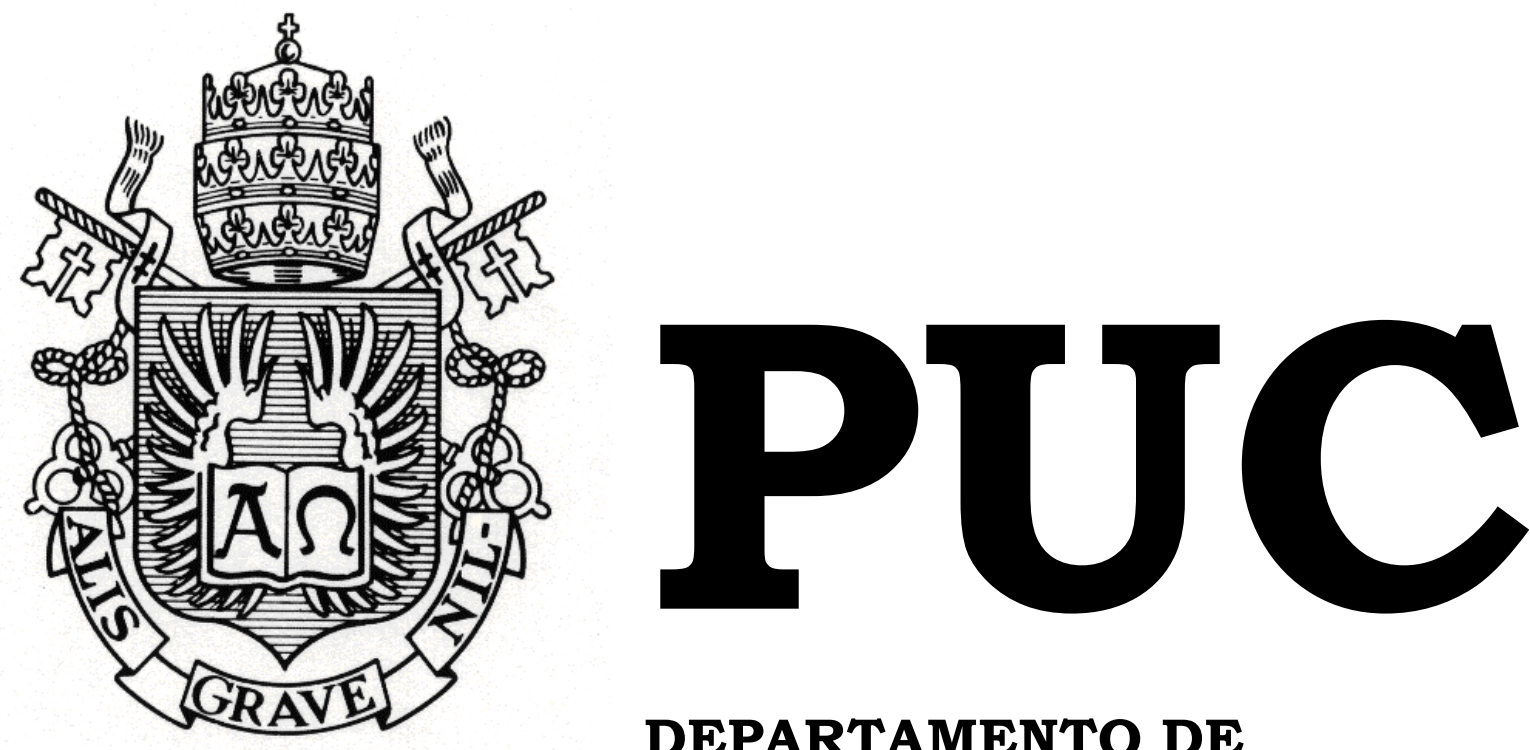

DEPARTAMENTO DE DIREITO

A MODULAÇÃO DOS EFEITOS DAS DECISÕES DO SUPREMO TRIBUNAL FEDERAL EM MATÉRIA TRIBUTÁRIA

por

ANA LUIZA MASSENA FERREIRA

ORIENTADOR: CARLOS HENRIQUE TRANJAN BECHARA

2010.1

PONTIFÍCIA UNIVERSIDADE CATÓLICA DO RIO DE JANEIRO RUA MARQUÊS DE SÃO VICENTE, 225 - CEP 22453-900 RIO DE JANEIRO - BRASIL 


\section{A MODULAÇÃO DOS EFEITOS DAS DECISÕES \\ DO SUPREMO TRIBUNAL FEDERAL EM \\ MATÉRIA TRIBUTÁRIA}

por

ANA LUIZA MASSENA FERREIRA

Monografia apresentada ao Departamento de Direito da Pontificia Universidade Católica do Rio de Janeiro (PUC-Rio) para a obtenção do Título de Bacharel em Direito.

Orientador: Carlos Henrique Tranjan Bechara 
Ao meu irmão,

Daniel, meu maior incentivador. 


\section{AGRADECIMENTOS}

À minha família, que sempre me transmitiu as forças necessárias para que seguisse em frente. Em especial, aos meus pais, Elizabeth e Elly e ao meu irmão, Daniel, pelo apoio incondicional e cooperação.

Ao meu orientador Carlos Henrique Tranjan Bechara, pelas valiosas lições em direito tributário e pela inestimável ajuda durante a elaboração desta monografia.

Aos meus amigos, Aline Campos de Leo, Jorge Eduardo Chagas Manso, Anna Clara Porthum Caruso, Luis Felipe Vidal Miguel, Andressa Machado e Anna Gabriela Barros Besser, por toda amizade e cumplicidade nos mais diferentes momentos.

Aos companheiros do escritório Rennó, Aragão e Lopes da Costa Advogados, sobretudo à equipe de tributário, José Andrés Lopes da Costa Cruz, Octávio Carneiro Silva Corrêa, Pedro Henrique Alves Santana e Patrícia Andrade da Fonseca, cuja compreensão, incentivo e ajuda foram fundamentais à realização deste trabalho.

Por fim, um agradecimento especial à minha amiga Raphaella Magnino Rosa Portilho, pela ajuda na pesquisa bibliográfica. 


\section{RESUMO}

O Brasil sempre defendeu a retroatividade dos efeitos das decisões proferidas em sede de controle de constitucionalidade (efeitos ex tunc). No entanto, esse posicionamento vem sendo mitigado, em especial, após a entrada em vigor da lei n. 9.868 que dispõe, em seu artigo 27, sobre a modulação dos efeitos das decisões proferidas pelo Supremo Tribunal Federal em sede de controle concentrado de constitucionalidade. Sob esta perspectiva, procura-se estudar a modulação de efeitos das decisões de inconstitucionalidade proferidas pelo Supremo Tribunal Federal em sede de controle concentrado de constitucionalidade, bem como em sede de controle difuso e em casos de mudança de orientação jurisprudencial, dando especial enfoque às decisões proferidas no âmbito tributário. O objetivo do presente trabalho é analisar as decisões em matéria tributária nas quais a modulação de efeitos foi suscitada e observar, nesses casos, os parâmetros sob os quais a atribuição de efeitos prospectivos vem sendo admitida pelos Ministros do Supremo Tribunal Federal. 


\section{PALAVRAS-CHAVE}

DIREITO CONSTITUCIONAL E TRIBUTÁRIO. DECISÕES DO SUPREMO TRIBUNAL FEDERAL. CONTROLE DE CONSTITUCIONALIDADE. MODULAÇÃO DE EFEITOS. INTERESSE SOCIAL. SEGURANÇA JURÍDICA. PROPORCIONALIDADE. 


\section{ABREVIAÇÕES}

ADI - Ação direta de inconstitucionalidade

AgR - Agravo regimental

AI- Agravo de instrumento

Art. - Artigo

CC - Conflito de competência

COFINS - Contribuição social para o financiamento da seguridade social

ED - Embargos de declaração

$\mathrm{HC}$ - Habeas corpus

IPI - Imposto sobre produtos industrializados

IPTU - Imposto sobre propriedade predial e territorial urbana

Min - Ministro

Rcl - Reclamação

RE - Recurso extraordinário

Rel. - Relator

Resp- Recurso Especial

RTJ - Revista Trimestral de Jurisprudência

STF - Supremo Tribunal Federal

STJ - Superior Tribunal de Justiça 


\section{SUMÁRIO}

INTRODUÇÃO

1) O CONTROLE DE CONSTITUCIONALIDADE E A MODULAÇÃO DE EFEITOS NO DIREITO COMPARADO....

1.1 - A Suprema Corte Americana e a doutrina do prospective overruling.

1.2 - As técnicas de decisão em sede de controle de constitucionalidade desenvolvidas na Áustria e Alemanha

2) O CONTROLE DE CONSTITUCIONALIDADE E A MODULAÇÃO DE EFEITOS NO BRASIL

2.1 - O sistema brasileiro de controle de constitucionalidade

2.2 - As primeiras manifestações em defesa da modulação de efeitos no Supremo Tribunal Federal.

\section{3) MODULAÇÃO DE EFEITOS NO CONTROLE} CONCENTRADO

3.1 - O artigo 27 da Lei n. 9.868/99: considerações sobre sua constitucionalidade.

3.2 - Análise dos requisitos formais necessários à modulação de efeitos presentes no artigo 27 da Lei n. 9.868/99.

3.3 - A ponderação de bens e a proporcionalidade como princípio instrumental na modulação de efeitos

3.4 - Critério material de ponderação: interesse social relevante e segurança jurídica 


\section{4) A MODULAÇÃO DE EFEITOS NO CONTROLE}

DIFUSO

4.1 - A modulação de efeitos e sua repercussão sobre o sistema difuso de controle de constitucionalidade.

4.2 - Da possibilidade de modulação de efeitos em casos de mudança de jurisprudência.

5) MODULAÇÃO DE EFEITOS NO ÂMBITO TRIBUTÁRIO.

5.1 - Análise da norma tributária: a norma impositiva e a norma exonerativa.

5.2 - A modulação de efeitos nas declarações de inconstitucionalidade de normas impositivas.

5.3 - A modulação de efeitos nas declarações de inconstitucionalidade de normas exonerativas.

5.4 - A modulação de efeitos em casos de mudança de jurisprudência em matéria tributária...

5.5 - Análise da modulação dos efeitos de decisões proferidas pelo Supremo Tribunal Federal em matéria tributária. 


\section{INTRODUÇÃO}

A Lei 9.868, de 10 de novembro de 1999, que regulamentou a ação direta de inconstitucionalidade e a ação declaratória de constitucionalidade, trouxe algumas inovações ao nosso ordenamento jurídico. Dentre estas inovações, destaca-se a possibilidade de modulação dos efeitos das decisões de declaração de inconstitucionalidade.

Tal previsão encontra-se no artigo 27 do diploma legislativo mencionado, nos seguintes termos: "Ao declarar a inconstitucionalidade de lei ou ato normativo, e tendo em vista razões de segurança jurídica ou de excepcional interesse social, poderá o Supremo Tribunal Federal, por maioria de dois terços de seus membros, restringir os efeitos daquela declaração ou decidir que ela só tenha eficácia a partir de seu trânsito em julgado ou de outro momento que venha a ser fixado."

A constitucionalidade do dispositivo é questionada nas ações declaratórias de inconstitucionalidade de números 2.154 e 2.258, o que não tem impedido o Supremo Tribunal Federal de aplicar o referido dispositivo. Com efeito, ao longo do presente trabalho, pretende-se demonstrar que a modulação de efeitos vem sendo admitida pelo Supremo Tribunal Federal desde antes da entrada em vigor do artigo 27 da Lei $n^{\circ}$ 9.868/99, sendo utilizada, inclusive, em sede de controle difuso de constitucionalidade, bem como em hipóteses de mudança de orientação jurisprudencial.

Sob essa perspectiva, nosso foco incidirá sobre a repercussão das decisões proferidas pelo Supremo Tribunal Federal nas quais a modulação de efeitos foi discutida, com especial ênfase nas decisões em matéria tributária. 
No primeiro capítulo, analisaremos os sistemas de controle de constitucionalidade adotados pelos Estados Unidos, Alemanha e Áustria, de forma a analisar como as questões referentes aos efeitos das decisões de inconstitucionalidade vêm sendo solucionadas nos ordenamentos alienígenas.

No segundo capítulo, será traçado um breve panorama do sistema de controle de constitucionalidade brasileiro, analisando-se, em seguida, as primeiras manifestações em prol da modulação de efeitos emitidas pelos Ministros do Supremo Tribunal Federal.

No terceiro capítulo, nosso foco incidirá em estudar os requisitos presentes no artigo 27 da Lei $n^{\circ}$ 9.868/99 necessários à modulação de efeitos no sistema concentrado de constitucionalidade. Nesta seara, será analisado o princípio da proporcionalidade como balizador das ponderações realizadas pelo julgador a fim de que a produção de efeitos da lei declarada inconstitucional encontre reflexos na própria Constituição, bem como o conceito de interesse social relevante e segurança jurídica, incluindo-se aqui uma análise do papel dos princípios da boa-fé e da proteção da confiança a justificar o emprego da técnica de modulação dos efeitos.

No capítulo quarto, iremos analisar as repercussões da modulação de efeitos sobre o sistema difuso de controle de constitucionalidade e também a possibilidade de sua utilização pelo Supremo Tribunal Federal em casos de mudança de jurisprudência.

Finalmente, no capítulo quinto, nosso estudo recairá sobre a questão da modulação de efeitos das decisões do Supremo Tribunal Federal em âmbito tributário. Aqui, examinaremos os efeitos da modulação de efeitos de declaração de inconstitucionalidade de normas tributárias impositivas e exonerativas, assim como a possibilidade de modulação de efeitos das decisões em matéria tributária quando houver mudança de orientação jurisprudencial. Ao final, analisaremos algumas decisões proferidas pelo 
Supremo Tribunal Federal em matéria tributária, de forma a observar os parâmetros pelos quais a modulação de efeitos vem sendo admitida nesses casos. 


\section{CAPÍTULO PRIMEIRO}

\section{O controle de constitucionalidade e a modulação de efeitos no direito comparado}

\subsection{A Suprema Corte Americana e a doutrina do prospective overruling}

Optamos por iniciar o presente trabalho com uma análise de alguns aspectos do sistema de controle de constitucionalidade norte-americano, dada sua importância no estudo da nulidade das normas inconstitucionais.

Os Estados Unidos adotaram o sistema difuso de controle de constitucionalidade, no qual é reservado a qualquer juiz o poder de declarar a inconstitucionalidade de uma norma suscitada em um caso concreto ${ }^{1}$. A tese adotada pelos Estados Unidos em seu sistema de controle de constitucionalidade preceitua que a lei que contraria a Constituição caracteriza-se como nula, sendo incapaz de produzir qualquer efeito ${ }^{2}$. A idéia remonta aos escritos do Federalista, no qual Alexander Hamilton já se pronunciava a respeito da primazia do Poder Judiciário para atuar como intérprete das leis e da validade destas perante a Lei Maior ${ }^{3}$.

\footnotetext{
${ }^{1}$ HURTADO, Ricardo Augusto Saavedra. A modulação dos efeitos temporais das decisões do Supremo Tribunal Federal em controle de constitucionalidade em matéria tributária. Rio de Janeiro. 2008. 82p. Monografia apresentada ao Programa de Pós-Graduação da Escola Superior de Advocacia Pública do Estado (ESAP) em convênio com a Faculdade de Direito da Universidade do Estado do Rio de Janeiro, p.11.

${ }^{2}$ SARAIVA. Luciana de Pontes. A modulação de efeitos como técnica de decisão na jurisdição constitucional. Rio de Janeiro. 2009. 153p. Dissertação apresentada ao Programa de Pósgraduação em direito público da Faculdade de Direito da Universidade do Rio de Janeiro, p.14.

3“"Algumas dúvidas se têm suscitado sobre o direito atribuído aos tribunais de justiça de declarar nulos, como contrários à Constituição, atos do corpo legislativo; porque se pensa que de semelhante doutrina resultaria a superioridade do Poder Judiciário sobre a legislatura, visto que uma autoridade não pode declarar nulos os atos de outra sem que lhe seja necessariamente superior (...)Todo ato de uma autoridade delegada contrário aos termos da comissão é nulo. Esse princípio é indubitável; e, portanto, todo ato do corpo legislativo, contrário à Constituição, não pode ter validade. Negar isso seria o mesmo que dizer que o delegado é superior ao constituinte, o criado ao amo, os representantes do povo ao povo que representam; ou aqueles que obram em virtude de poderes delegados, tanta autoridade têm para que esses poderes autorizam, como para o que eles proíbem (...) A Constituição é e deve ser considerada pelos juízes como lei fundamental; e como a
} 
O postulado da nulidade da lei contrária à Constituição ganhou ainda mais força com a célebre decisão da Suprema Corte dos Estados Unidos no caso Marbury vs Madison ${ }^{4}$, na qual foi estabelecida a possibilidade de controle de constitucionalidade das leis pelo Poder Judiciário, passando a Constituição a figurar como Lei Maior e diretriz para todas as outras leis ${ }^{5}$.

\section{A decisão em comento foi verdadeiro marco no sistema de controle} de constitucionalidade, consolidando o judicial review e a teoria da nulidade da norma jurídica inconstitucional, teoria esta que adotou o caráter das decisões de reconhecimento de inconstitucionalidade das normas como declaratório.

Em virtude do caráter declaratório da decisão de inconstitucionalidade, os efeitos desta decisão retroagem até o momento da entrada da lei no mundo jurídico, não havendo, portanto, como se admitir

interpretação das leis é função especial dos tribunais judiciários, a eles pertence determinar o sentido da Constituição, assim como de todos os outros atos do corpo legislativo. Se entre estas leis se encontrarem algumas contraditórias, deve preferir aquela, cuja observância é um dever mais sagrado; que é o mesmo que dizer que a Constituição deve ser preterida a um simples estatuto; ou a intenção do povo a dos seus agentes" HAMILTON, Alexander, MADISON, James e JAY, John. O Federalista, artigo 78. Belo Horizonte: Ed. Líder, 2003, p. 459.

${ }^{4}$ Mauro Cappelletti destaca que o principio da primazia da Constituição defendido pelo Chief Justice John Marshall no caso Marbury vs Madison já existia de uma forma rudimentar em antigos sistemas jurídicos tais como o ateniense e o medieval. CAPPELLETTI, Mauro. O controle judicial de constitucionalidade das leis no direito comparado. $2^{\mathrm{a}}$ ed. Porto Alegre: Fabris,1984, $\mathrm{p}$. 46-63.

"'So, if a law be in opposition to the Constitution, if both the law and the Constitution apply to a particular case, so that the Court must either decide that case conformably to the law, disregarding the Constitution, or conformably to the Constitution, disregarding the law, the Court must determine which of these conflicting rules governs the case. This is of the very essence of judicial duty. If, then, the Courts are to regard the Constitution, and the Constitution is superior to any ordinary act of the Legislature, the Constitution, and not such ordinary act, must govern the case to which they both apply. Those, then, who controvert the principle that the Constitution is to be considered in court as a paramount law are reduced to the necessity of maintaining that courts must close their eyes on the Constitution, and see only the law". (Portanto, se a lei estiver em oposição à Constituição, se ambas a lei e a Constituição forem aplicáveis ao caso concreto, o Tribunal deverá decidir o caso ou conforme a lei, desconsiderando a Constituição, ou conforme a Constituição, desconsiderando a lei. O Tribunal precisará decidir qual das leis conflitantes será aplicada ao caso. Isto está na essência do dever judicial. Se, portanto, os Tribunais devem respeito à Constituição e a Constituição é superior a qualquer ato ordinário do Legislativo, a Constituição, e não a lei deve regular o caso ao qual ambas se aplicam. Aqueles, portanto, que desrespeitam o princípio de que a Constituição deve ser considerada como uma lei paradigma serão forçados a concluir que os tribunais devem fechar os olhos para a Constituição e enxergar somente a lei) Disponível em http://www.law.cornell.edu/supct/html/historics/USSC_CR_0005_0137_ZO.html. Acesso em 06.04.2010. 
efeitos válidos de uma lei inconstitucional, uma vez que todas as relações jurídicas constituídas com base na lei inconstitucional retornam ao status anterior ${ }^{6}$.

Assim, desde a decisão do caso Marbury vs Madison, vem sendo adotada nos Estados Unidos a teoria da nulidade da norma jurídica inconstitucional, considerando-se como declaratório os efeitos das decisões proferidas em sede de controle de constitucionalidade.

Deve ser destacado que, mesmo sendo as decisões proferidas em sede de controle concreto de constitucionalidade no sistema norteamericano, os tribunais recorrem ao stare decisis ${ }^{7}$, o que confere, ainda que de maneira transversa, efeitos erga omnes à decisão de inconstitucionalidade ${ }^{8}$.

Isto porque, através do stare decisis, os juízes ficam vinculados às decisões da Suprema Corte, devendo utilizar os mesmos princípios utilizados por esta no caso paradigma (leading case) em casos análogos, o que amplia os efeitos das decisões proferidas pela Corte a terceiros que não fizeram parte do processo ${ }^{9}$. Dessa forma, os efeitos retroativos decorrentes da pronúncia de nulidade de uma lei julgada inconstitucional podem, de certa forma, ultrapassar os limites do caso concreto.

A Suprema Corte vem mitigando os efeitos dessa retroatividade através da doutrina do prospective overruling, que permite aos juízes da Suprema Corte pronunciar a nulidade de leis sem a atribuição de eficácia retroativa em casos de superação de precedentes.

\footnotetext{
${ }^{6}$ BARROSO, Luis Roberto. O controle de constitucionalidade no Direito Brasileiro. $4^{\mathrm{a}}$ ed. São Paulo: Saraiva, 2009, p. 16.

${ }^{7}$ Cabe destacar que o stare decisis norte-americano somente recai sobre o núcleo do julgado (ratio decidendi), não operando sobre as ponderações paralelas e circunstanciais que não compõem os fundamentos determinantes da decisão. SARAIVA. Luciana de Pontes . Op. Cit., p. 126.

${ }^{8}$ BARROSO, Luis Roberto. Op. Cit., p. 17.

${ }^{9}$ Ibid., p. 17.
} 
O julgamento do caso Linkletter $v$. Walker rompeu com a teoria de retroatividade das decisões proferidas pela Suprema Corte, permitindo a atribuição de eficácia prospectiva a algumas decisões. No caso em questão, Linkletter havia sido condenado em processo criminal fundado em provas ilícitas. Ocorre que a Suprema Corte, em julgamento do caso Mapp v. Ohio, havia se manifestado no sentido de que a utilização de provas ilícitas constituía afronta à $4^{a}$ Emenda. Em virtude da mudança de precedente, a Suprema Corte foi instada a se manifestar sobre a aplicação do precedente firmado em Mapp v. Ohio ao caso específico de Linkletter, no qual já havia ocorrido condenação.

A Suprema Corte afirmou que "na Constituição não existem indicações que determinem a implantação retroativa de regras de exclusão", determinando que as partes litigantes tivessem seu processo julgado de acordo com o direito vigente na data de sua conduta, uma vez que a reabertura de casos em que já houvesse condenação criaria uma situação custosa e inaceitável para os Estados. A decisão em comento também determinou a observância de três fatores para a concessão de efeitos prospectivos: a) os propósitos a serem atingidos pelo novo precedente, b) o grau de confiança na jurisprudência anterior e c) os efeitos decorrentes da aplicação do novo precedente ${ }^{10}$.

A Suprema Corte também utilizou a doutrina do prospective overruling no caso Chevron Oil Co. vs. Huson. O caso resumia-se a determinar se o entendimento firmado em Rodrigue v. Aetna Casualty \& Surety $C o$. poderia ser utilizado ao caso em comento. O precedente firmado em Rodrigue v. Aetna Casualty \& Surety Co. estabelecia que, em matéria de prazo para a propositura de ação de reparação, deveria ser aplicada lei estadual, superando entendimento anterior que estabelecia a aplicação da lei

\footnotetext{
${ }^{10} \mathrm{APPIO}$, Eduardo. Controle difuso de constitucionalidade: modulação dos efeitos, uniformização de jurisprudência e coisa julgada. $1^{\text {a }}$ reimpr. Curitiba: Juruá, 2010, p. 74.
} 
federal. A Suprema Corte reconheceu a incidência da lei estadual, porém negou a aplicação de eficácia retroativa, afirmando que o caso em questão era anterior à mudança de orientação da Suprema Corte, não podendo o postulante ser prejudicado por esta alteração de entendimento ${ }^{11}$.

Recentemente, a Suprema Corte vem afastando a possibilidade de se conceder efeitos prospectivos às suas decisões no âmbito de controle de constitucionalidade, derrubando, inclusive, o precedente firmado em Linkletter $v$. Walker.

Em matéria tributária, a concessão de efeitos prospectivos sofre resistência na Suprema Corte, prevalecendo a tese da retroatividade. Em Harper v. Virginia Departament of Taxation, caso que tratava de repetição de indébito de tributo inconstitucional, a Suprema Corte determinou que deveria ser aplicada a plena retroatividade da lei. Sobre o assunto afirmou o Juiz Scalia em seu voto:

\footnotetext{
"a técnica das decisões prospectivas é serva do ativismo judicial e inimiga de nascença do stare decisis. Ela foi formulada no ápice do realismo jurídico e promovida como técnica de criação judicial de normas (tecnique of judicial lawmaking), em geral, e mais especificamente, como um meio para tornar mais fácil a superação de precedentes anteriores (...) A doutrina verdadeiramente tradicional é a de que a decisão prospectiva é incompatível com o poder judicial, e que as cortes não têm autoridade para aderir à sua prática" ${ }^{\prime 12}$.
}

\footnotetext{
${ }^{11}$ HURTADO, Ricardo Augusto Saavedra. Op. Cit., p. 21-22.

${ }^{12}$ Apud. SARAIVA. Luciana de Pontes. Op. Cit., p. 19-20.
} 


\subsection{As técnicas de decisão em sede de controle de constitucionalidade desenvolvidas na Áustria e Alemanha}

Ao contrário do sistema difuso de controle de constitucionalidade adotado nos Estados Unidos, a Áustria e a Alemanha adotam o sistema concentrado de constitucionalidade, no qual a competência para examinar a compatibilidade entre a lei aplicável e a Constituição é outorgada a um órgão especializado - corte constitucional ${ }^{13}$.

Embora o sistema de controle de constitucionalidade adotado por esses dois países seja o concentrado, se diferem no tocante aos efeitos das decisões proferidas em sede de controle de constitucionalidade.

No modelo austríaco, influenciado pela concepção kelsiana, uma lei inconstitucional é considerada válida e deve ser utilizada pelos juízes e tribunais até que a Corte Constitucional decida por declarar sua inconstitucionalidade. Após esta decisão, a lei é retirada do ordenamento jurídico. Dessa forma, a inconstitucionalidade da lei não gera uma nulidade, mas somente a anulabilidade do ato. Assim, a decisão que considera a lei como inconstitucional possui efeitos ex nunc, não retroagindo até o momento de criação da lei ${ }^{14}$.

\footnotetext{
${ }^{13}$ MARTINS, Ives Gandra da Silva e MENDES, Gilmar Ferreira. Controle Concentrado de Constitucionalidade. Comentários à Lei n. 9.868, de 10-11-1999. $3^{\text {a }}$ ed. São Paulo: Saraiva, 2009, p. 1.

${ }^{14}$ Nesse sentido leciona Mauro Cappelletti: "Resumindo, então: enquanto o sistema norteamericano de controle judicial de legitimidade constitucional das leis tem o caráter de um controle meramente declarativo, o sistema austríaco assume, ao invés, o caráter de um controle constitutivo da invalidade e da consequente ineficácia das leis que contrastam com a Constituição; e disto, com total coerência, deriva, ainda, que, enquanto no primeiro sistema, a eficácia (meramente declarativa) opera, em princípio, ex tunc, retroativamente - trata-se, de fato, de mero acertamento de uma pré-existente nulidade absoluta - no sistema austríaco, ao contrário, a eficácia (constitutiva, ou seja, de anulação) do pronunciamento de inconstitucionalidade opera ex nunc ou, com toda certeza, pro futuro, não se admitindo qualquer retroatividade da eficácia da anulação. CAPPELLETTI, Mauro. Op. cit., p. 117.
} 
Embora tradicionalmente a decisão de inconstitucionalidade tenha efeitos constitutivos, a Corte Constitucional austríaca vem admitindo a modulação dos efeitos temporais de suas decisões. $\mathrm{O}$ artigo $140, \mathrm{n}^{\circ} 5$, da Constituição austríaca ${ }^{15}$ permite à Corte fixar um prazo de até 18 meses para que a lei inconstitucional continue a produzir efeitos a partir da declaração de sua anulação. A norma evita lacunas que poderiam surgir da declaração de anulação com efeitos ex nunc, conferindo tempo ao legislador para que nova regulamentação seja elaborada ${ }^{16}$.

É importante destacar, ainda, que em casos julgados em controle concreto de constitucionalidade, o qual permite a análise da lei em um caso específico, a decisão da Corte Constitucional austríaca possui efeito retroativo ${ }^{17}$. Constata-se, portanto, que mesmo na Áustria, o sistema de controle de constitucionalidade encontrou percalços, havendo situações em que a eficácia ex nunc das decisões sofreu temperamentos ${ }^{18}$.

\footnotetext{
${ }^{15}$ Art. 140 (5) The judgment by the Constitutional Court which rescinds a law as unconstitutional imposes on the Federal Chancellor or the competent Governor the obligation to publish the rescission without delay. This applies analogously in the case of a pronouncement pursuant to Paragraph (4). The rescission enters into force on the day of the publication if the Court does not set a deadline for the rescission. This deadline may not exceed eighteen months". Disponível em http://vescc.az/constitution/austria-constitution-eng.html. Acesso em 30.05.2010.

${ }^{16}$ MARTINS, Ives Gandra da Silva e MENDES, Gilmar Ferreira. Op. Cit., p. 499.

${ }^{17}$ SORMANI, Alexandre. Inovações da ação direta de inconstitucionalidade e da ação declaratória de constitucionalidade: uma visão crítica da Lei n. 9.868/99 sob o viés do princípio da segurança jurídica. São Paulo: Juarez de Oliveira, 2004, p. 75.

${ }^{18}$ Sobre o assunto, observa Mauro Cappelletti: "No sistema austríaco, ao invés, a norma inconstitucional, repito, é considerada perfeitamente válida e eficaz até o momento em que for publicado, sem força retroativa, o pronunciamento da Corte Constitucional (...). De tudo isso resultaria a consequência, perfeitamente lógica e coerente em teoria, mas, evidentemente, absurda e inaceitável na prática, de que o pronunciamento da Corte Constitucional não poderia ter qualquer eficácia justamente em relação aqueles casos concretos, pendentes perante o Oberster Gerichtshof ou o Verwaltungsgerichtshof, no curso dos quais tenha surgido a questão de constitucionalidade. Exatamente para obstar esta absurda consequência (...) o sistema reformado de 1919 admitiu que limitadamente ao caso concreto, por cuja ocasião tenha surgido, "em via de exceção", a questão da constitucionalidade - a lei contrária à Constituição deva, em seguida ao pronunciamento da Corte Constitucional, ter aplicação recusada também em relação aos fatos verificados antes do pronunciamento. O próprio Kelsen, em um escrito de 1929, viria realmente a reconhecer que "cet effet rétroactif de l'annulation est une nécessité technique parce que, sans lui, les autorités chargées de l'application du droit n'auraient pas d'intérêt immédiat et par suite suffisamment puissant à provoquer l'intervention du tribunal constitutionnel...Il faut les encourager à presenter ces requêts en attribuant dans ce cas à l'annulation un effet rétroactif'. CAPPELLETTI, Mauro. Op. cit., p. 121-122.
} 
O mesmo se deu na Alemanha que, embora adote a regra de produção de efeitos retroativos de suas decisões, tal como o sistema norteamericano, criou diversas técnicas para temperar a regra da retroatividade dos efeitos das leis declaradas inconstitucionais.

Dentre as técnicas de decisão adotadas pelo Tribunal Constitucional alemão, merecem destaque a declaração de inconstitucionalidade sem pronúncia de nulidade e o apelo ao legislador.

A declaração de inconstitucionalidade sem pronúncia de nulidade ocorre quando a declaração de nulidade com efeitos retroativos se mostra inadequada para sanar o vício. Na prática, é uma decisão com efeitos prospectivos. Esta técnica de decisão ocorre com frequência em casos de exclusão de benefício incompatível com o princípio da isonomia e em casos de omissão legislativa.

Gilmar Ferreira Mendes, ao conceituar exclusão de benefício incompatível com o princípio da isonomia afirma que esta exclusão "se verifica quando a lei, de forma arbitrária, concede benefícios a determinado grupo de cidadãos, excluindo, expressa ou implicitamente, outros segmentos ou setores" 19.

A exclusão de benefício incompatível com o princípio da isonomia pode ser concludente ou explícita. É concludente se o benefício é concedido somente a determinado grupo e explícita se a lei determina de forma expressa a exclusão de determinado grupo do benefício ${ }^{20}$.

\footnotetext{
${ }^{19}$ De acordo com Gilmar Ferreira Mendes, a exclusão de benefício incompatível com o princípio da isonomia "pode ser afastada de diversas maneiras: pela supressão do próprio benefício; pela inclusão dos grupos eventualmente discriminados ou até mediante a edição de uma nova regra, que condicione a outorga dos benefícios à observância de determinados requisitos decorrentes do princípio da igualdade.” MARTINS, Ives Gandra da Silva e MENDES, Gilmar Ferreira. Op. Cit., p. 513-514.

${ }^{20}$ Ibid., p. 514.
} 
Em ambos os casos, a declaração de inconstitucionalidade da norma não poderia possuir efeitos retroativos. Sobre a necessidade de efeitos prospectivos, Gilmar Ferreira Mendes conclui:

\footnotetext{
"a relação normativa inconstitucional (verfassungswidrige Normrelation) não pode ser superada, em princípio, mediante decisão de índole cassatória, pois esta ou não atingiria os objetivos pretendidos ou acabaria por suprimir algo mais do que a ofensa constitucional que se pretende eliminar" ${ }^{21}$.
}

Outra situação na qual a declaração de inconstitucionalidade sem pronúncia de nulidade é utilizada com frequência são os casos de omissão legislativa total (quando a lei simplesmente não foi editada) e parcial (quando a lei é insuficiente). Nestes casos, a declaração de inconstitucionalidade com efeitos retroativos não é medida adequada ao saneamento do vício, uma vez que acarretaria lacuna legislativa que se afastaria ainda mais do ideal constitucional, razão pela qual a técnica de declaração de inconstitucionalidade sem pronúncia de nulidade é adotada ${ }^{22}$.

Outra técnica de decisão utilizada pelo Tribunal Constitucional alemão é o apelo ao legislador. Neste caso, não há declaração de inconstitucionalidade, porém o Tribunal adverte que a situação poderá se converter a um estado de inconstitucionalidade caso o legislador não altere a lei em um determinado prazo $^{23}$.

Esta técnica foi utilizada pela primeira vez em 04 de maio de 1954, em julgamento sobre o Estatuto do Sarre, no qual ficou estabelecido que as providências tomadas pelo legislador a fim de superar o "estatuto de ocupação" não deveriam ser consideradas inconstitucionais, uma vez que

\footnotetext{
${ }^{21}$ Ibid., p. 515-516.

${ }^{22}$ HURTADO, Ricardo Augusto Saavedra. Op. Cit., p. 27.

${ }^{23}$ SORMANI, Alexandre. Op. Cit., p. 124.
} 
contribuíam para a compatibilização da situação jurídica com a Lei Fundamental $^{24}$.

A técnica de apelo ao legislador foi também utilizada em decisão do Bundesverfassungsgericht, de 22 de maio de 1963. No caso em questão, em decorrência de alterações na estrutura demográfica de unidades federadas, a divisão dos distritos eleitorais passou a não mais atender o princípio da igualdade eleitoral. O Tribunal constatou que houve ofensa à Lei Fundamental, porém não declarou a inconstitucionalidade da norma, somente advertiu ao legislador da necessidade de implementação de medidas que alterassem a divisão dos distritos eleitorais. O pedido do Tribunal foi atendido com a promulgação da Lei de 14 de fevereiro de $1964^{25}$.

Embora existam críticas feitas à técnica de apelo ao legislador ${ }^{26}$, sua importância não pode ser desconsiderada, visto que esta técnica de decisão tem sido responsável por profundas reformas legislativas ${ }^{27}$.

\footnotetext{
${ }^{24}$ MARTINS, Ives Gandra da Silva e MENDES, Gilmar Ferreira. Op. Cit., p. 507-508.

${ }^{25}$ MENDES, Gilmar Ferreira. Direitos Fundamentais e Controle de Constitucionalidade: estudos de direito constitucional. $3^{\mathrm{a}}$ ed. São Paulo: Saraiva, 2004, p. 407/409.

${ }^{26}$ Gilmar Ferreira Mendes, ao comentar a técnica de apelo ao legislador ressalta que o "apelo" para que se corrija uma situação ainda constitucional (noch Verfassungsmãßige Rechtslage), antes que se consolide o estado de inconstitucionalidade, não obriga, juridicamente, o órgão legislativo a empreender qualquer providência. Esse entendimento há de aplicar-se, igualmente, na hipótese de a Corte Constitucional incorporar o "apelo" à parte dispositiva da decisão, uma vez que apenas o conteúdo de decisões expressamente previstas em lei - declaração de constitucionalidade, declaração de inconstitucionalidade, declaração de nulidade - pode fazer coisa julgada ou ser dotado de força de lei. A manifestação do Bundesverfassungsgericht sobre o processo de inconstitucionalização há de ser considerada simples obter dictum. É muito provável que a qualificação do "apelo ao legislador" como mero obter dictum não corresponda à intenção da Corte Constitucional, que, não raras vezes, estabelece, de forma imperativa, a situação que há de substituir após a decisão, como v.g., no julgado sobre os filhos havidos fora do casamento (Lei Fundamental, art. 6, v). Outras vezes, determina o Tribunal que o legislador proceda às mudanças reclamadas dentro de determinado espaço de tempo. É fácil de compreender, no entanto, que a sentença de rejeição de inconstitucionalidade não pode ser proferida com a imposição de um dever de legislar. Esse dever não pode assentar-se no § 31, (1), da Lei do Bundesverfassungsgericht, uma vez que o efeito vinculante não abrange todos e quaisquer fundamentos da decisão, mas, tãosomente, aqueles imprescindíveis à prolação do julgado." MARTINS, Ives Gandra da Silva e MENDES, Gilmar Ferreira. Op. Cit., p. 511/512.

${ }^{27}$ Sobre o assunto, comenta Gilmar Ferreira Mendes: "Não devem ser desconsideradas, todavia, as consequências fáticas do apelo ao legislador. O peculiar significado que os órgãos estatais - e a opinião pública - atribuem aos pronunciamentos da Corte Constitucional asseguram às appellentscheidungen eficácia comparável a qualquer outra decisão de índole mandamental ou
} 
Percebe-se, portanto, que assim como nos Estados Unidos e na Áustria, as técnicas de decisão adotadas na Alemanha vêm admitindo temperamentos dos efeitos de suas decisões, a fim de "responder aos reclamos de uma jurisdição constitucional mais efetiva" 28.

cassatória. O apelo ao legislador tem dado ensejo, não raras vezes, a profundas reformas legislativas, como demonstram os julgados proferidos sobre a situação dos filhos havidos fora do casamento (Lei Fundamental, art. 6, par. 5), sobre a problemática da execução penal, e a respeito das relações jurídicas nas escolas públicas". MENDES, Gilmar Ferreira. Op. Cit., p. 424.

${ }^{28}$ SARAIVA. Luciana de Pontes. Op. Cit., p. 22. 


\section{CAPÍTULO SEGUNDO}

\section{O controle de constitucionalidade e a modulação de efeitos no Brasil}

\subsection{O sistema brasileiro de controle de constitucionalidade}

O controle de constitucionalidade no Brasil é jurisdicional, combinando os critérios difuso e concentrado.

O controle concentrado foi introduzido no Brasil por meio da Emenda Constitucional n ${ }^{\circ} 16$, de 06 de dezembro de 1965, que atribuiu ao Supremo Tribunal Federal (STF) a competência para processar e julgar originariamente a representação de inconstitucionalidade de lei ou ato normativo federal ou estadual, encaminhada por Procurador-Geral da República $^{29}$.

A partir desse momento, o controle por via de ação direta tomou um perfil definido, passando a ser possível o exame de constitucionalidade por via de ação direta destinada, exclusivamente, a sanar dúvida sobre a constitucionalidade de dispositivo normativo em tese, sem estar vinculado a um caso concreto ${ }^{30}$.

Com a promulgação da Constituição de 1988, o rol de legitimados a proporem a ação direta de inconstitucionalidade aumentou, passando a abranger não só o Procurador-Geral da República como também o Presidente da República, a Mesa do Senado Federal, a Mesa da Câmara dos Deputados, a Mesa da Assembléia Legislativa, o Governador do Estado, o Conselho da Ordem dos Advogados do Brasil, partido político com

\footnotetext{
${ }^{29}$ MORAES, Alexandre de. Direito Constitucional. 19a ed. São Paulo: Atlas, 2006, p. 664.

${ }^{30}$ BONAVIDES, Paulo. Curso de Direito Constitucional. 18 ${ }^{\mathrm{a}}$ ed. São Paulo: Malheiros, 2006, p.330.
} 
representação no Congresso Nacional e confederação sindical ou entidade de classe em âmbito nacional.

A Constituição de 1988 trouxe ainda uma segunda inovação: a ação de inconstitucionalidade por omissão. Dessa forma, possuímos atualmente duas ações diretas de inconstitucionalidade: a ação de inconstitucionalidade por ação e a por omissão ${ }^{31}$.

A inconstitucionalidade por ação se dá quando o ato legislativo ou administrativo é incompatível com norma ou princípio constitucional. A inconstitucionalidade, nesse caso, pode ser formal ou material. A inconstitucionalidade formal se dá quando a norma foi elaborada por autoridade incompetente ou em desacordo com procedimento previsto na Constituição. A inconstitucionalidade material, por sua vez, ocorre quando o conteúdo da lei é contrário ao dispositivo constitucional ${ }^{32}$.

A inconstitucionalidade por omissão verifica-se nos casos em que os atos legislativos ou administrativos necessários para a aplicação da norma constitucional não foram praticados ${ }^{33}$.

Como já mencionado, o controle por via de ação direta discute a lei em abstrato, sem estar vinculado a um caso concreto. Dessa forma, as decisões proferidas pelo Supremo Tribunal Federal nas ações diretas de

\footnotetext{
${ }^{31}$ Atualmente, existe também a ação declaratória de constitucionalidade, a arguição de descumprimento de preceito fundamental e ação direta de inconstitucionalidade interventiva (art. 34, VII, da Constituição Federal), porém estas não serão objeto do presente estudo.

${ }^{32}$ SILVA, José Afonso da, Curso de Direito Constitucional Positivo. $27^{\mathrm{a}}$ ed. São Paulo: Malheiros, 2006, p. 47.

33“"A Constituição, por exemplo, prevê o direito de participação dos trabalhadores nos lucros e na gestão das empresas, conforme definido em lei, mas, se esse direito não se realizar, por omissão do legislador em produzir a lei aí referida e necessária à plena aplicação da norma, tal omissão se caracterizará como inconstitucional. Ocorre então, o pressuposto para a propositura de uma ação de inconstitucionalidade por omissão, visando obter do legislador a elaboração da lei em causa. Outro exemplo: a Constituição reconhece que a saúde e a educação são direitos de todos e dever do Estado (arts. 196 e 205), mas, se não se produzirem os atos legislativos e administrativos indispensáveis para que se efetivem tais direitos em favor dos interessados, aí, também, teremos uma omissão inconstitucional do Poder Público que possibilita a interposição da ação de inconstitucionalidade por omissão (art. 103)" Ibid., p. 47-48.
} 
inconstitucionalidade por ação, por terem como objeto a própria questão da constitucionalidade, possuem eficácia erga omnes e vinculam os demais órgãos do Poder Judiciário e a Administração Pública direta e indireta, nas esferas federal, estadual e municipal ${ }^{34}$, que não poderão mais aplicar a lei declarada inconstitucional ${ }^{35}$. A decisão que declara a inconstitucionalidade possui efeito retroativo, tendo em vista que o ordenamento brasileiro entende que os atos inconstitucionais são nulos desde sua origem. Assim, em regra, o ato declarado inconstitucional é desfeito desde sua criação, bem como as consequências dele originadas ${ }^{36}$.

Deve ser destacado que o ato declarado inconstitucional por via de ação direta de inconstitucionalidade sai do ordenamento jurídico de forma direta, não havendo necessidade de suspensão da execução pelo Senado Federal, como ocorre com as decisões proferidas no controle difuso de constitucionalidade, conforme será visto adiante ${ }^{37}$.

Em relação à declaração de inconstitucionalidade por omissão, a decisão que declara a inconstitucionalidade é declaratória e também

\footnotetext{
${ }^{34}$ Constituição Federal de 1988. Art. 102, § $2^{\text {o: }}$ "As decisões definitivas de mérito, proferidas pelo Supremo Tribunal Federal, nas ações diretas de inconstitucionalidade e nas ações declaratórias de constitucionalidade produzirão eficácia contra todos e efeito vinculante, relativamente aos demais órgãos do Poder Judiciário e à administração pública direta e indireta, nas esferas federal, estadual emunicipal"

Disponível em http://www.planalto.gov.br/ccivil_03/constituicao/Constitui\%C3\%A7ao.ht Acesso em 30.05.2010.

${ }^{35}$ Alexandre de Moraes entende que o efeito vinculante se aplica, inclusive, ao legislador, porém, o autor salienta que este não é o entendimento defendido pelo Supremo Tribunal Federal. MORAES, Alexandre de. Op. Cit., p. 691.

${ }^{36}$ Ibid., p. 687.

${ }^{37}$ Sobre o assunto, leciona Moreira Alves: "entre nós, como se adota o sistema misto de controle judiciário de inconstitucionalidade, se esta for declarada, no caso concreto, pelo Supremo Tribunal Federal, sua eficácia se limita às partes da lide, podendo o Senado Federal apenas suspender a execução, no todo ou em parte, de lei declarada inconstitucional por decisão definitiva do Supremo Tribunal Federal (art. 52, X, da Constituição). Já, em se tratando de declaração de inconstitucionalidade de lei ou de ato normativo por meio de ação direta de inconstitucionalidade, a eficácia dessa decisão é erga omnes e ocorre, refletindo-se sobre o passado, com o trânsito em julgado do aresto desta Corte". RTJ 151/331-355.
} 
mandamental, uma vez que exige do Poder competente a adoção das providências necessárias ao suprimento da omissão ${ }^{38}$.

No tocante à omissão de órgão administrativo, será dada ciência ao órgão competente para que adote as providências necessárias em trinta dias. A fixação de um prazo permite a responsabilização do órgão administrativo caso a omissão permaneça. Quando a omissão parte do Poder Legislativo, não há a imputação de um prazo para a adoção de providências. Em ambos os casos, não há previsão de sanção para o descumprimento da medida solicitada pelo Supremo Tribunal Federal, uma vez que o Poder Judiciário não tem poder para forçar o órgão competente a legislar, sob pena de afronta ao princípio da separação dos poderes ${ }^{39}$.

O controle difuso de constitucionalidade, por sua vez, existe no Brasil desde a Constituição de 1891 que já previa, em seu artigo 59, a possibilidade de recurso ao Supremo Tribunal Federal quando a decisão do Tribunal do Estado fosse contrária a dispositivo constitucional ${ }^{40}$. O controle difuso instalou-se no país com ainda mais força após o advento da Lei Federal $n^{\circ} 221$, de $1984^{41}$, que conferiu competência aos juízes e tribunais

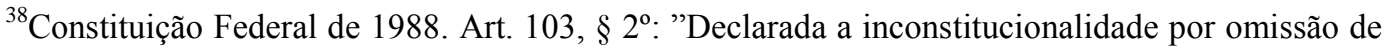
medida para tornar efetiva norma constitucional, será dada ciência ao Poder competente para a adoção das providências necessárias e, em se tratando de órgão administrativo, para fazê-lo em trinta dias."

Disponível em http://www.planalto.gov.br/ccivil_03/constituicao/Constitui\%C3\%A7ao.ht Acesso em 30.05.2010.

${ }^{39}$ Alexandre de Moraes entende que no caso de omissão do Poder Legislativo, dada ciência ao Poder Legislativo da inconstitucionalidade, "fixa-se judicialmente a ocorrência da omissão, com efeitos retroativos ex nunc e erga omnes, permitindo-se a sua responsabilização por perdas e danos, na qualidade de pessoa de direito público da União Federal, se da omissão correr qualquer prejuízo". MORAES, Alexandre de. Op. Cit., p. 698.

${ }^{40}$ Constituição Federal de 1891. Art. 59, § 1º "Das sentenças das Justiças dos Estados, em última instância, haverá recurso para o Supremo Tribunal Federal: a) quando se questionar sobre a validade, ou a aplicação de tratados e leis federais, e a decisão do Tribunal do Estado for contra ela; b) quando se contestar a validade de leis ou de atos dos Governos dos Estados em face da Constituição, ou das leis federais, e a decisão do Tribunal do Estado considerar válidos esses atos, ou essas leis impugnadas."

Disponível em http://www.planalto.gov.br/ccivil_03/constituicao/Constitui\%C3\%A7ao91.htm. Acesso em 30.05.2010.

${ }^{41}$ Lei Federal 221/1894. Art. 13, § 10: “Os juizes e tribunaes apreciarão a validade das leis e regulamentos e deixarão de applicar aos casos occurrentes as leis manifestamente inconstitucionais
} 
para analisarem a validade das leis e deixarem de aplicá-las ao caso concreto, quando concluíssem pela inconstitucionalidade da norma ${ }^{42}$.

Através do controle difuso, qualquer juiz ou tribunal pode realizar, no caso concreto, a análise da compatibilidade da norma com a Constituição Federal. Dessa forma, o controle de constitucionalidade só ocorrerá quando, no curso de uma ação, uma das partes levantar em sua defesa a inconstitucionalidade de uma lei aplicável ao caso.

Cabe ressaltar que no Brasil a inconstitucionalidade só poderá declarada por um Tribunal se for respeitada a cláusula de reserva de plenário $^{43}$. A cláusula em questão, prevista no artigo 97 da Constituição Federal de $1988^{44}$, determina que a inconstitucionalidade de uma lei só pode ser declarada pelo voto da maioria absoluta da totalidade de membros do tribunal ou dos integrantes do órgão especial, sob pena de nulidade da decisão proferida pelo órgão fracionário ${ }^{45}$.

\footnotetext{
e os regulamentos manifestamente incompatíveis com as leis ou com a Constituição.” Disponível em http://www.planalto.gov.br/ccivil_03/Leis/1851-1900/L0221.htm. Acesso em 30.05.2010.

${ }^{42}$ MORAES, Alexandre de. Op. Cit., p 647.

${ }^{43}$ Inicialmente, a cláusula de reserva de plenário era somente utilizada no controle difuso de constitucionalidade, porém, a partir da entrada do controle concentrado de constitucionalidade em nosso ordenamento, estendeu-se também a ele. BARROSO, Luis Roberto. Op. Cit., p. 96.

${ }^{44}$ Constituição Federal de 1988: Art. 97. Somente pelo voto da maioria absoluta de seus membros ou dos membros do respectivo órgão especial poderão os tribunais declarar inconstitucionalidade de lei ou ato normativo do Poder Público.

Disponível em http://www.planalto.gov.br/ccivil_03/constituicao/Constitui\%C3\%A7ao.htm. Acesso em 30.05.2010.

${ }^{45}$ Sobre o assunto, cabe transcrever observação de Alexandre de Moraes: "A Primeira Turma do Supremo Tribunal Federal, porém, entende, excepcionalmente, dispensável a aplicação do art. 97 da Constituição Federal, desde que presentes dois requisitos: a. existência anterior de pronunciamento da inconstitucionalidade da lei ou do ato normativo pelo Plenário do Supremo Tribunal Federal; b. a existência, no âmbito do tribunal a quo, e em relação àquele mesmo ato do Poder Público, de uma decisão plenária que haja apreciado a controvérsia constitucional, ainda que desse pronunciamento não tenha resultado o formal reconhecimento da inconstitucionalidade da regra estatal questionada. Há, porém, entendimento mais recente do Plenário do Supremo Tribunal Federal entendendo que "versando a controvérsia sobre ato normativo já declarado inconstitucional pelo guardião maior da Carta Política da República - o Supremo Tribunal Federal - descabe o deslocamento previsto no art. 97 do referido Diploma maior. O julgamento de plano pelo órgão fracionado homenageia não só a racionalidade, como também implica interpretação teleológica do art. 97 em comento, evitando a burocratização dos atos judiciais no que nefasta ao princípio da economia e da celeridade. A razão de ser do preceito está na necessidade de evitar-se que órgãos fracionados apreciem, pela primeira vez, a pecha de inconstitucionalidade arguida em relação a um certo ato normativo" MORAES, Alexandre de. Op. Cit., 648-649.
} 
As decisões proferidas em controle difuso de constitucionalidade, da mesma forma que aquelas proferidas no sistema concentrado, possuem efeito retroativo, uma vez que a lei considerada inconstitucional é nula desde o seu nascimento. No entanto, a eficácia da declaração de inconstitucionalidade só ocorre entre as partes da lide, não havendo o efeito erga omnes característico do sistema concentrado.

Para os fins do presente estudo, analisaremos somente as decisões proferidas pelo Supremo Tribunal Federal. A esse respeito, cabe enfatizar que o Supremo Tribunal Federal tem competência não só para declarar a inconstitucionalidade de uma lei mediante o sistema concentrado como também de forma incidental, sendo a forma mais corriqueira de utilização do controle difuso pelo Supremo Tribunal Federal o julgamento de recurso extraordinário $^{46}$.

O recurso extraordinário somente cuida de questões de direito constitucional que tenham sido objeto de prequestionamento, ou seja, que tenham sido discutidas nas instâncias inferiores. A ofensa à Constituiçãa, em regra, deverá ser direta, não sendo conhecidos os recursos que apresentem ofensa indireta ou reflexa. O recurso é utilizado quando a decisão recorrida: (i) contraria dispositivo da Constituição, (ii) declara a inconstitucionalidade de tratado ou lei federal, (iii) julga válida lei ou ato de governo local contestado em face desta Constituição ou (iv) julga válida lei local contestada em face de lei federal ${ }^{47}$.

\footnotetext{
46، Também ao Supremo Tribunal Federal, como estudado, cabe declarar incidentalmente a inconstitucionalidade de uma lei. Poderá fazê-lo em causa de sua competência originária - e.g., um mandado de segurança contra ato do Presidente da República (CF, art. 102, I, d) -, ao julgar recurso ordinário - e.g., interposto contra a denegação de uma habeas corpus pelo Superior Tribunal de Justiça (art. 102, II, a) - ou na apreciação de um recurso extraordinário" BARROSO, Luis Roberto. O controle de constitucionalidade no Direito Brasileiro. $4^{\mathrm{a}}$ ed. São Paulo: Saraiva, 2009, p. 128.

${ }^{47}$ Art. 102 Compete ao Supremo Tribunal Federal, precipuamente, a guarda da Constituição, cabendo-lhe: III- julgar, mediante recurso extraordinário, as causas decididas em única ou última instância, quando a decisão recorrida: a) contrariar dispositivo desta Constituição; b) declarar a inconstitucionalidade de tratado ou lei federal; c) julgar válida lei ou ato de governo local contestado em face desta Constituição e d) julgar válida lei local contestada em face de lei federal.
} 
Cabe mencionar, ainda, que a questão constitucional discutida deverá ter repercussão geral. O Código de Processo Civil entende que a questão terá repercussão geral quando versar sobre tema de relevância econômica, social, política ou jurídica que transcendam aos interesses das partes envolvidas no processo ${ }^{48}$.

Nas declarações de inconstitucionalidade de lei proferidas pelo Supremo Tribunal Federal em sede de controle por via incidental, notadamente as decisões proferidas em julgamento de recursos extraordinários, os efeitos da decisão seguem a regra geral de eficácia inter partes. No entanto, a Constituição Federal prevê um mecanismo de ampliação dos efeitos desta declaração incidental de inconstitucionalidade, prevista no artigo 52, inciso X, da Constituição Federal ${ }^{49}$.

O dispositivo em comento prevê a comunicação da decisão proferida pelo Supremo Tribunal Federal ao Senado Federal que poderá, através de resolução, suspender a execução, no todo ou em parte, da lei declarada inconstitucional $^{50}$.

Disponível em http://www.planalto.gov.br/ccivil_03/constituicao/Constitui\%C3\%A7ao.htm. Acesso em 30.05.2010.

${ }^{48}$ Código de Processo Civil. Art. 543-A. "O Supremo Tribunal Federal, em decisão irrecorrível, não conhecerá do recurso extraordinário, quando a questão constitucional nele versada não oferecer repercussão geral, nos termos deste artigo. § $1^{\circ}$ Para efeito da repercussão geral, será considerada a existência, ou não, de questões relevantes do ponto de vista econômico, político, social ou jurídico, que ultrapassem os interesses subjetivos da causa." Disponível em http://www.planalto.gov.br/ccivil_03/Leis/L5869.htm Acesso em 30.05.2010.

${ }^{49}$ Art. 52. Compete privativamente ao Senado Federal: X - suspender a execução, no todo ou em parte, de lei declarada inconstitucional por decisão definitiva do Supremo Tribunal Federal. Obtido em http://www.planalto.gov.br/ccivil_03/constituicao/constitui\%C3\%A7ao.htm Disponível em 30.05.2010.

${ }^{50}$ Sobre o assunto, cabe transcrever dispositivos do Regimento Interno do Senado Federal que regem o assunto: "Art. 386: O Senado conhecerá da declaração, proferida em decisão definitiva pelo Supremo Tribunal Federal, de inconstitucionalidade total ou parcial de lei mediante: I comunicação do Presidente do Tribunal; II - representação do Procurador-Geral da República; III - projeto de resolução de iniciativa da Comissão de Constituição, Justiça e Cidadania. Art. 387: A comunicação, a representação e o projeto a que se refere o art. 386 deverão ser instruídos com o texto da lei cuja execução se deva suspender, do acórdão do Supremo Tribunal Federal, do parecer do Procurador- Geral da República e da versão do registro taquigráfico do julgamento. Art. 388: Lida em plenário, a comunicação ou representação será encaminhada à Comissão de Constituição, Justiça e Cidadania, que formulará projeto de resolução suspendendo a execução da lei, no todo ou em parte.” Disponível em http://www.senado.gov.br/sf/legislacao/regsf/RegSFVolI.pdf Acesso em 30.05.2010. 
Deve ser ressaltado, contudo, que a atuação do Senado Federal possui caráter discricionário ${ }^{51}$. Nas palavras de Luís Roberto Barroso, “trata-se de ato político, não sujeito a prazo, podendo o Senado suspender o ato normativo, no todo ou em parte, ou simplesmente não suspendê-lo, negando, assim, a extensão erga omnes da decisão do Supremo”, 52.

Pelo exposto, percebe-se que as decisões proferidas em sede de controle difuso de constitucionalidade possuem efeitos inter partes, exceto nos casos de utilização do artigo 52, inciso X, da Constituição Federal, quando a suspensão da execução da lei poderá ter efeitos erga omnes ${ }^{53}$.

Outra inovação que vem trazendo mudanças nos efeitos das decisões de inconstitucionalidade proferidas em controle difuso é a inserção da súmula vinculante em nosso ordenamento jurídico. Através da súmula vinculante, prevista no artigo $103-\mathrm{A}$ da Constituição Federal ${ }^{54}$, o Supremo Tribunal Federal vincula os demais órgãos do Poder Judiciário e a administração pública direta e indireta que, a partir da publicação da súmula, não poderão mais aplicar entendimento diverso daquele apontado

\footnotetext{
51، O Senado, como regra, suspende a execução do ato declarado inconstitucional. Há, contudo, precedente de não-suspensão: no caso do art. $9^{\circ}$ da Lei n. 7.689 , de 15 de dezembro de 1988 , que instituiu a contribuição social sobre o lucro das pessoas jurídicas. O referido dispositivo teve sua inconstitucionalidade declarada incidentalmente no RE 150.764-PE (DJU, 2 abr. 1993, rel. Min. Sepúlveda Pertence), por maioria apertada. O Senado Federal foi comunicado da decisão em ofício de 16 de abril de 1993. A matéria foi apreciada pela Comissão de Constituição e Justiça, que se manifestou pela não suspensão da norma, em parecer terminativo de 28 de outubro de 1993 (DCN2, 29 out. 1993, p. 10028) Não houve recurso contra essa decisão, que se tornou definitiva em 5 de novembro de 1993, tendo sido comunicada à Presidência da República e ao Presidente do Supremo Federal no dia 18 do mesmo mês" BARROSO, Luis Roberto. $O$ controle de constitucionalidade no Direito Brasileiro. $4^{\text {a }}$ ed. São Paulo: Saraiva, 2009, p. 129.

${ }^{52}$ Ibid., p. 129.

${ }^{53}$ Sobre o assunto é necessário destacar posicionamento de Luís Roberto Barroso a respeito da atribuição de efeitos à suspensão do ato normativo declarado inconstitucional pelo Senado: "embora a matéria ainda suscite ampla controvérsia doutrinária, afigura-se fundada em melhor lógica e em melhores argumentos a atribuição de efeitos ex tunc à suspensão do ato normativo pelo Senado" Ibid., p. 130.

${ }^{54}$ Constituição Federal Art. 103-A. "O Supremo Tribunal Federal poderá, de ofício ou por provocação, mediante decisão de dois terços dos seus membros, após reiteradas decisões sobre matéria constitucional, aprovar súmula que, a partir de sua publicação na imprensa oficial, terá efeito vinculante em relação aos demais órgãos do Poder Judiciário e à administração pública direta e indireta, nas esferas federal, estadual e municipal, bem como proceder à sua revisão ou cancelamento, na forma estabelecida em lei"

Disponível em http://www.planalto.gov.br/ccivil_03/constituicao/constitui\%C3\%A7ao.htm. Acesso em 30.05.2010.
} 
pelo Supremo Tribunal Federal. Luciana de Pontes Saraiva ao analisar a aplicação de súmulas vinculantes em nosso ordenamento conclui:

o exercício do controle difuso foi mitigado, visto que, a partir da publicação da súmula vinculante, não caberá ao juiz ou Tribunal a quo exercer o controle incidental em contrariedade ao entendimento veiculado na súmula editada ${ }^{55}$.

A partir do exposto até o momento, podemos concluir que impera no Brasil a tese da retroatividade da lei declarada inconstitucional, alternandose os efeitos da decisão no tocante a abrangência da eficácia dada à declaração de inconstitucionalidade, que será erga omnes no sistema concentrado e, em regra, inter partes no sistema difuso. No entanto, determinados mecanismos ${ }^{56}$, tais como o requisito de repercussão geral e as súmulas vinculantes, vêm favorecendo a uniformização dos precedentes dos Tribunais, mitigando o caráter inter partes das decisões proferidas no âmbito do controle difuso 57 .

\subsection{As primeiras manifestações em defesa da modulação de efeitos no Supremo Tribunal Federal}

Conforme analisado anteriormente, a regra no direito brasileiro é o efeito retroativo das decisões proferidas em sede de controle de constitucionalidade, uma vez que a lei considerada inconstitucional é considerada nula desde o seu nascimento.

\footnotetext{
${ }^{55}$ SARAIVA, Luciana de Pontes. Op. Cit., p. 130.

${ }^{56}$ Além dos mecanismos citados, podemos mencionar também as súmulas impeditivas de recurso, bem como os incidentes de uniformização de jurisprudência previstos nos artigos 476 a 479 do Código de Processo Civil.

${ }^{57}$ Sobre o assunto, leciona Luciana de Pontes Saraiva: “A propensão, portanto, é que também as decisões proferidas em controle difuso de constitucionalidade acabem por repercutir para toda a sociedade, em função dos mecanismos que induzem à uniformização da jurisprudência produzida pelo nosso Tribunal Constitucional. Essa tendência será apenas reforçada, caso se confirme a jurisprudência do Supremo Tribunal Federal pela possibilidade de retirada de norma impugnada do ordenamento jurídico a partir da própria declaração incidental de inconstitucionalidade, independente da existência de resolução do Senado". SARAIVA, Luciana de Ponte. Op. Cit., p. 101.
} 
Como será demonstrado adiante, esta regra vem sofrendo temperamentos, em especial, após a entrada de dispositivos em nosso ordenamento jurídico que permitiram a modulação dos efeitos de declarações de inconstitucionalidade proferidas pelo Supremo Tribunal Federal em controle concentrado, bem como dos efeitos das súmulas vinculantes aprovadas pelo Tribunal ${ }^{58}$.

Apesar da possibilidade de modulação dos efeitos das decisões do Supremo Tribunal Federal ter surgido no ordenamento jurídico brasileiro somente em 1999, a ideia não é nova, já tendo sido levantada em alguns julgados do STF em datas anteriores às publicações das Leis n ${ }^{\circ} \mathrm{s}$ 9.882/99 e 9868/99, precursoras da entrada da tese da modulação de efeitos no sistema brasileiro de controle de constitucionalidade.

O Ministro Leitão de Abreu já se manifestava a respeito da possibilidade de temperamento da teoria da retroatividade dos efeitos das leis declaradas constitucionais em voto proferido na década de 1970 durante o julgamento do Recuro Extraordinário n. 79.343. No caso em questão, o Ministro Relator se demonstrou a favor da teoria kelsiana de anulabilidade da lei inconstitucional, defendendo que as relações jurídicas pautadas na

\footnotetext{
${ }^{58}$ Lei n. 9.882/99. "Art. 11. Ao declarar a inconstitucionalidade de lei ou ato normativo, no processo de arguição de descumprimento de preceito fundamental, e tendo em vista razões de segurança jurídica ou de excepcional interesse social, poderá o Supremo Tribunal Federal, por maioria de dois terços de seus membros, restringir os efeitos daquela declaração ou decidir que ela só tenha eficácia a partir de seu trânsito em julgado ou de outro momento que venha a ser fixado." Disponível em http://www.planalto.gov.br/ccivil 03/Leis/L9882.htm Acesso em 30.05.2010. Lei n. 9868/99 Art. 27. "Ao declarar a inconstitucionalidade de lei ou ato normativo, e tendo em vista razões de segurança jurídica ou de excepcional interesse social, poderá o Supremo Tribunal Federal, por maioria de dois terços de seus membros, restringir os efeitos daquela declaração ou decidir que ela só tenha eficácia a partir de seu trânsito em julgado ou de outro momento que venha a ser fixado." Disponível em http://www.planalto.gov.br/ccivil 03/Leis/L9868.htm. Acesso em 30.05.2010.

Lei n.11.417/2006 Art. 4 "A súmula com efeito vinculante tem eficácia imediata, mas o Supremo Tribunal Federal, por decisão de $2 / 3$ (dois terços) dos seus membros, poderá restringir os efeitos vinculantes ou decidir que só tenha eficácia a partir de outro momento, tendo em vista razões de segurança jurídica ou de excepcional interesse público." Disponível em http://www.planalto.gov.br/ccivil/_Ato2004-2006/2006/Lei/L11417.htm. Acesso em 30.05.2010.
} 
boa-fé não poderiam ser prejudicadas pela retroatividade dos efeitos da lei inconstitucional $^{59}$. Confira-se trecho do voto proferido pelo Relator:

(...) a lei inconstitucional é um ato eficaz, ao menos antes da determinação da inconstitucionalidade, podendo ter consequências que não é lícito ignorar. A tutela da boa-fé exige que, em determinadas circunstâncias, notadamente quando, sob a lei ainda não declarada inconstitucional, se estabelecerem relações entre o particular e o poder público, se apure, prudencialmente, até que ponto a retroatividade da decisão, que decreta a inconstitucionalidade, pode atingir, prejudicando o agente que teve por legítimo o ato e, fundado nele, operou na presunção de que estava procedendo sob o amparo do direito positivo ${ }^{60}$.

No caso em comento, a modulação dos efeitos da decisão não foi admitida, porém nos julgamentos dos Recursos Extraordinários $78.209^{61} \mathrm{e}$ $78.594^{62}$ foi decidido que os atos praticados por servidores públicos investidos em cargo público com base em lei inconstitucional deveriam ser considerados válidos ${ }^{63}$. No voto proferido pelo Ministro Relator Aliomar Baleeiro fica consignado:

"uma coisa é a inconstitucionalidade da lei (...) outra, as consequências jurídicas dos atos materiais e até dos atos jurídicos por eles [servidores do Executivo irregularmente investidos das funções de oficiais de justiça] praticados (...) antes da declaração daquela inconstitucionalidade" ${ }^{64}$.

No julgamento dos Recursos Extraordinários $n^{\circ} \mathrm{s} \quad 105.789^{65} \mathrm{e}$ $122.202^{66}$ foi afastada norma que assegurava aos magistrados direito à gratificação, porém permaneceram os pagamentos da gratificação, a fim de

\footnotetext{
${ }^{59}$ SILVA, Renata Elaine. Modulação dos efeitos da decisão em matéria tributária: possibilidade ou não de "restringir os efeitos daquela declaração". Revista Dialética de Direito Tributário. São Paulo, n ${ }^{\circ} 170$, p. 52-63, nov.2009, p. 52-53.

${ }^{60}$ STF, RE 79343, Relator Min. Leitão de Abreu, $2^{\mathrm{a}}$ Turma, julgado em 31.05.1977, DJ 02.09.1977.

${ }^{61}$ STF, RE 78209, Relator Min. Aliomar Baleeiro, $1^{\text {a }}$ Turma, julgado em 04.06.1974, DJ 11.10.1974.

${ }^{62}$ STF, RE 78594, Relator Min. Bilac Pinto, 2a Turma, julgado em 07.06.1974, DJ 04.11.1974.

${ }^{63}$ No mesmo sentido foram julgados os REs n ${ }^{\circ}$ 79.682/SP (STF, Relator Min. Moreira Alves, Tribunal Pleno, julgado em 13.05.1976, DJ 01.04.1977) e 78.533/SP (STF, Relator Ministro Firmino Paz, $2^{\text {a }}$ Turma, julgado em 13.11.1981, DJ 26.02.1982).

${ }^{64}$ Apud. GODOI, Marciano Seabra de. O consequencialismo jurídico e as modulações dos efeitos das decisões do STF. In ROCHA, Valdir de Oliveira (Org.). Grandes Questões Atuais do Direito Tributário. $13^{\circ}$ volume. São Paulo: Dialética, 2009, p. 298.

${ }^{65}$ STF, RE 105789, Relator Min. Carlos Madeira, julgado em 15.04.1986, DJ 09.05.1986.

${ }^{66}$ STF, RE 122202, Relator Min. Francisco Rezek, julgado em 10.08.1993, DJ 08.04.1994.
} 
que não ocorresse violação à garantia constitucional de irredutibilidade de vencimentos ${ }^{67}$.

Após a promulgação da Constituição de 1988, mas ainda em fase anterior à publicação da Lei n. 9.868/99, o Supremo Tribunal Federal continuou a admitir a mitigação dos efeitos da declaração de inconstitucionalidade. Em julgamento da ADI $1.102^{68}$ foi declarada a inconstitucionalidade com efeitos ex tunc de norma de arrecadação tributária. No entanto, o Relator destacou que seu entendimento pessoal era no sentido de que a inconstitucionalidade somente surtisse efeito após a concessão de medida cautelar, uma vez que "os resultados consequenciais da decisão impõem drásticas restrições ao orçamento da seguridade social, abalada por notória insuficiência de caixa" 69.

No mesmo julgamento, o Ministro Sepúlveda Pertence afirmou ser favorável à modulação dos efeitos das decisões proferidas em sede de controle de constitucionalidade, desde que não existam indícios que indiquem que o STF irá se posicionar pela inconstitucionalidade da lei. No caso concreto, o Ministro optou pela concessão de efeitos ex tunc, uma vez que uma norma muito semelhante à discutida no caso já havia sido considerada inconstitucional pelo STF. O Ministro Sepúlveda Pertence alertou, ainda, que a modulação dos efeitos da declaração de inconstitucionalidade somente poderia ser admitida em casos excepcionais, uma vez que essa solução poderia estimular a criação de normas inconstitucionais $^{70}$.

\footnotetext{
${ }^{67}$ ÁVILA, Ana Paula. A modulação de efeitos temporais pelo STF no controle de constitucionalidade: ponderação e regras de argumentação para a interpretação conforme a Constituição do artigo 27 da Lei $n^{\circ}$ 9.868/99. Porto Alegre: Livraria do Advogado Editora, 2009. p. 48.

${ }^{68}$ STF, ADI 1102, Relator Min. Maurício Corrêa, Tribunal Pleno, julgado em 05.10.1995, DJ 17.11.1995.

${ }^{69}$ Apud. GODOI, Marciano Seabra de. Op. Cit., p. 299.

${ }^{70}$ Marciano Seabra de Godoi, ao comentar o voto proferido pelo Ministro Sepúlveda Pertence ressalta o alerta feito pelo Ministro no sentido de que a pronúncia de efeitos ex nunc no campo tributário poderia "estimular aventuras por parte do Executivo ou do Legislativo, dado que a
} 
Por fim, é de destacar o julgamento do RE $147.776^{71}$. O caso em questão tratava da inconstitucionalidade do artigo 68 do Código de Processo Penal (art. 68) que legitimava o Ministério Público a promover, no juízo cível, o ressarcimento de dano resultante de crime. Ocorre que a Constituição de 1988 conferiu essa competência à Defensoria Pública, estando o artigo 68, portanto, incompatível com o Texto Constitucional. Não obstante a incompatibilidade da lei em comento com o dispositivo constitucional, o Tribunal entendeu que o artigo 68 do Código de Processo Penal continuaria vigente até que a Defensoria Pública fosse devidamente estruturada, uma vez que "a implementação de uma nova ordem constitucional não é um fato instantâneo, mas um processo, no qual a possibilidade de realização da norma da Constituição (...) subordina-se muitas vezes a alterações da realidade fáctica que a viabilizem."

Percebe-se, portanto, que mesmo antes da existência de dispositivo normativo que permitisse a modulação dos efeitos, esta já era admitida e muitas vezes até implementada pelos Ministros do Supremo Tribunal Federal, tanto no sistema concentrado como no sistema difuso de controle de constitucionalidade.

declaração de inconstitucionalidade será incapaz de reverter o considerável fluxo de valores já recolhidos aos cofres públicos no momento do pronunciamento do STF”. Ibid., p. 300.

${ }^{71}$ STF, RE 147776, Relator Min. Sepúlveda Pertence, Primeira Turma, julgado em 19.05.1998, DJ 19.06.1998. 


\section{CAPÍTULO TERCEIRO \\ Modulação de efeitos no controle concentrado}

\section{1. $\quad 0$ artigo 27 da Lei n. 9.868/99: considerações sobre sua constitucionalidade}

Em 10 de novembro de 1999, foi promulgada a Lei n. 9.868 que regulamentou a ação direta de inconstitucionalidade e a ação declaratória de constitucionalidade $^{72}$. A lei em comento prevê, em seu artigo $27^{73}$, a possibilidade de flexibilização dos efeitos das decisões proferidas em sede de controle concentrado de constitucionalidade, nos seguintes termos:

Art. 27. Ao declarar a inconstitucionalidade de lei ou ato normativo, e tendo em vista razões de segurança jurídica ou de excepcional interesse social, poderá o Supremo Tribunal Federal, por maioria de dois terços de seus membros, restringir os efeitos daquela declaração ou decidir que ela só tenha eficácia a partir de seu trânsito em julgado ou de outro momento que venha a ser fixado.

$\mathrm{O}$ artigo em questão permitiu ao Supremo Tribunal Federal modular os efeitos da declaração de inconstitucionalidade, seja no tocante aos seus efeitos temporais, seja em relação à sua amplitude, desde que a decisão seja proferida por dois terços dos membros do Tribunal e estejam presentes razões de segurança jurídica ou de excepcional interesse social ${ }^{74}$.

Dessa forma, podemos dizer que este dispositivo normativo enrijeceu o sistema de atribuição de efeitos das leis declaradas inconstitucionais, exigindo que a modulação dos efeitos preencha os requisitos mencionados.

\footnotetext{
${ }^{72}$ Como já mencionado anteriormente, não analisaremos a arguição de descumprimento de preceito fundamental, motivo pelo qual a Lei n. 9.882/1999 não será objeto do presente estudo.

${ }^{73} \mathrm{O}$ artigo em questão foi influenciado por dispositivo semelhante previsto na Constituição portuguesa em seu art. 282, item 4, que determina que o Tribunal Constitucional poderá fixar os efeitos da inconstitucionalidade ou da ilegalidade com alcance mais restrito ao previsto em geral, quando a segurança jurídica, razões de equidade ou interesse público de excepcional relevo o exigir.

${ }^{74}$ MORAES, Alexandre de. Op. Cit. p. 688-689.
} 
O artigo 27 da Lei n. 9.868/99 foi recebido com apreensão por parte da doutrina que entende que o referido dispositivo confere poderes muito amplos ao Supremo Tribunal Federal, o que poderia ocasionar temperamentos dos efeitos das decisões por motivos exclusivamente políticos. ${ }^{75} \mathrm{O}$ receio de parte da doutrina em aceitar o dispositivo previsto na Lei n. 9.868 é justificável, tendo em vista a responsabilidade que recai nos membros do Supremo Tribunal Federal como "guardiões da Constituição". Essa desconfiança possui ainda mais fundamento em sede de controle concentrado, quando as decisões possuem efeitos erga omnes e vinculam o Poder Judiciário como um todo, bem como os órgãos da administração pública ${ }^{76}$.

Alguns doutrinadores chegam, inclusive, a alegar ser inconstitucional o artigo ora em debate ${ }^{77}$. Em suma, aqueles que defendem a

\footnotetext{
${ }^{75}$ FERREIRA FILHO, Manoel Gonçalves. O sistema constitucional brasileiro e as recentes inovações no controle de constitucionalidade. Revista de Direito Administrativo, São Paulo, n. 220, p. 1-17, abr/jun. 2000, p.3.

No mesmo sentido se posiciona Gilmar Mendes que entende que a modulação de efeitos não pode ocorrer em casos nos quais os argumentos sejam simplesmente de política judiciária ou conveniência política. GODOI, Marciano Seabra de. Op. Cit. p. 307.

${ }^{76}$ Sobre o assunto, cabe transcrever lição de García de Enterría: "La técnica de la anulación prospectiva se há desarrollado em las jurisprudencias constitucionales de otros países y en la de los Tribunales supranacionales europeos em función de um prolema específico del control judicial de las leyes. Em palavras ya clásicas de Otto Bachof em su trabajo 'El juez constitucional entre el Derecho y la Política'(al que yo mismo me he referido detenidamente en el livro citado, La Constitución como Norma, pp. 199 y sigs.), porque las sentencias anulatorias de una ley 'pueden ocasionar catástrofes, no solo para el caso concreto, sino para um invisible número de casos; cuando esas sentencias son 'politicamente equivocadas' (em el sentido de que desbaratan las tareas políticas legítimas de la dirección del Estado), la decisión puede alcanzar a la comunidad política entera'.Así, pues, más que el juez de otros ámbitos de la justicia, puede e debe el juez constitucional no perder de vista las consecuencias $-\mathrm{y}$ tan frecuentemente consecuencias políticas - de sus sentencias. Pero - y ésta es la cuestión a plantearse - ¿Qué influencia le es permitido conceder a esas eventuales consecuencias sobre su sentencia?¿¿Puede, le es permitido o debe declarar ineficaz la ejecutión de uma Ley aplicada incólumemente durante largos años declarando una nulidad que privara de soporte a innumerables actos jurídicos, o quizá derriblar a sectores enteros administrativos o económicos a causa de uma infracción constitucional tardíamente descubierta? ¿No se convertiría aqui de hecho el summun ius em summa inuria, sin utilidad para nadie y daño para muchos o para la entera comunidad?"GARCÍA DE ENTERRÍA, Eduardo. Justicia Constitucional: la doctrina prospectiva em la declaración de ineficacia de las leyes inconstitucionales. Revista de Direito Público, São Paulo, v. 22, n 92, p. 5-16, out.-dez, 1989, p. 12-13.

${ }^{77}$ Dentre os autores que alegam a inconstitucionalidade da modulação de efeitos temporais da declaração de inconstitucionalidade, destacamos SARLET, Info Wolfgang. Arguição de Descumprimento de Preceito Fundamental: Alguns aspectos controversos. In: Arguição de Descumprimento de Preceito Fundamental: Análises à Luz da Lei n. 9.882/1999. São Paulo; Atlas, 2001. p. 164-165; MACIEIRA, Luciana de Assunção. A inconstitucionalidade do art. 27 da Lei
} 
inconstitucionalidade do artigo 27 da Lei n. 9.868/99 afirmam que o dispositivo encontra-se em flagrante violação à regra da nulidade inconstitucional, que determina a retroatividade dos efeitos de toda e qualquer decisão que declare a inconstitucionalidade de uma norma. Dessa forma, ao violar a regra da nulidade dos atos inconstitucionais, haveria também uma violação ao princípio da supremacia da Constituição, reconhecendo, ainda que somente por um período, a eficácia de uma norma contrária aos dispositivos constitucionais ${ }^{78}$.

Outro argumento levantado quanto à inconstitucionalidade do dispositivo é que este deveria ter entrado no ordenamento jurídico por meio de Emenda Constitucional, uma vez que a regra do artigo 27 da Lei n. 9.868/99 possui natureza constitucional, havendo, portanto, uma inconstitucionalidade formal que impediria a utilização do dispositivo previsto na Lei n. 9.868/99.

$\mathrm{O}$ argumento de inconstitucionalidade formal do artigo é consistente, especialmente se considerarmos que na constituinte de 1987 (por iniciativa do então senador Maurício Corrêa) e na revisão constitucional de 1994 (por iniciativa do então deputado Nelson Jobim) tentou-se introduzir dispositivo muito semelhante ao artigo 27 da Lei n. 9.868/99, tendo sido ambas as propostas rejeitadas $^{79}$.

Em decorrência dessa alegação de inconstitucionalidade, tanto formal quanto material, foram interpostas duas ações diretas de inconstitucionalidade para impugnar o artigo 27 da Lei n. 9.868/99, autuadas sob os n ${ }^{\circ}$ s. 2.154 e 2.258. Sepúlveda Pertence, em sessão de 16 de agosto de 2007, proferiu voto no sentido de julgar procedente as ações diretas de inconstitucionalidade propostas, tendo em vista a inconstitucionalidade formal do dispositivo. No mesmo sentido, já se

9.868/99 quanto ao regulamento processual dos efeitos do provimento final em sede de controle abstrato. In: Revista da ESMAPE, v. 6, n. 13, p. 291-309, jan/jun 2001, p. 302.

${ }^{78}$ ÁVILA, Ana Paula. Op. Cit. p.63-64.

${ }^{79}$ GODOI, Marciano Seabra de. Op. Cit. p. 304. 
manifestou o Ministro Moreira Alves em julgamento de Agravo Regimental na Reclamação 1.880 (STF, Rcl 1880, Pleno, Relator Ministro Maurício Corrêa, julgado em 07.11.2002, DJ 19.03.2004) ${ }^{80}$.

As ações diretas de inconstitucionalidade ainda não foram julgadas. Entretanto, mesmo com a manifestação de dois Ministros do Supremo Tribunal a favor da inconstitucionalidade do dispositivo, é pouco provável que as ações sejam julgadas procedentes, uma vez que o próprio STF já utilizou o dispositivo em questão em diversas ocasiões, não só no âmbito da via direta, como também no controle incidental e difuso de constitucionalidade.

Embora tenha sido recebido com receio por parte da doutrina, muitos receberam bem a possibilidade de modulação de efeitos presente no dispositivo normativo em questão. Carlos Roberto Siqueira Castro afirma que o dispositivo "exterioriza a grande contribuição congressual para o tema”. No mesmo sentido, se manifestou Daniel Sarmento, para quem " $a$ inovação introduzida pelo art. 27 da Lei n. 9.868 é, em linha geral, digna de encômios, na medida em que outorgou ao STF os poderes necessários para que este tenha como exercer, a contento, a sua missão de guardião da Lei Maior" ${ }^{81}$.

A doutrina que apóia a constitucionalidade do referido dispositivo normativo entende que o artigo 27 da Lei n. 9.868/99 deve ser interpretado conforme a Constituição, ${ }^{82}$ não havendo que se falar em violação ao

\footnotetext{
${ }^{80}$ GODOI, Marciano Seabra de. Op. Cit., p. 304.

${ }^{81}$ Apud. SILVA, Sergio André R. G. comentário acerca dos Efeitos da Decisão Proferida no Âmbito do Controle Abstrato da Constitucionalidade das Normas Tributárias. Revista Dialética de Direito Tributário, São Paulo, n 83,p. 150-167, ago.2002., p. 150.

${ }^{82}$ Sobre o assunto, é importante mencionar que no voto proferido pelo Ministro Sepúlveda Pertence no julgamento das ADIs $n^{\circ} \mathrm{s} 2.154$ e 2.258, no qual o Ministro decidiu pela inconstitucionalidade formal do art. 27 da Lei n. 9.868/99, o Ministro afirma que ainda que pudesse ser ultrapassada a questão da inconstitucionalidade formal do dispositivo, este teria que ser interpretado conforme a Constituição de forma a evitar que sua aplicação pudesse atingir o ato jurídico perfeito, a coisa julgada e o direito adquirido, eventualmente surgidos da inconstitucionalidade da lei. GODOI, Marciano Seabra de. Op. Cit., p. 304.

No mesmo sentido se posiciona Alexandre Sormani que afirma; "o dispositivo merece, então, uma interpretação conforme a Constituição: a segurança jurídica e o expecional interesse social não
} 
princípio da primazia da Constituição ou do princípio da nulidade da lei declarada inconstutucional. $\mathrm{Na}$ verdade, o dispositivo em comento simplesmente regula os aspectos formais e materiais de uma situação em que deverão ser ponderadas as normas constitucionais que ensejaram a declaração de inconstitucionalidade e as normas constitucionais que justificam a preservação dos efeitos do ato inconstitucional ${ }^{83}$.

Expostos os argumentos elencados pela doutrina a respeito da constitucionalidade ou inconstitucionalidade do dispositivo, é necessário destacar que, ainda que seja declarada sua inconstitucionalidade, esta não implicará no fim da modulação dos efeitos das decisões de inconstitucionalidade proferidas pelo Supremo Tribunal Federal. Conforme já analisado, o STF vem se manifestando no sentido de possibilidade de modulação dos efeitos de suas decisões desde a década de 1970. Dessa forma, a modulação de efeitos continuaria a ocorrer, porém, sem a obrigação de respeito aos requisitos impostos pelo artigo 27 da Lei n. $9.868 / 99$.

No presente trabalho, focaremos nosso estudo nos requistos previstos no artigo 27 da Lei n. 9.868, tendo em vista que, não obstante a discussão

\footnotetext{
permitem o reconhecimento jurídico de uma invalidade, assim, a Corte não poderá, sob tais justificativas, apenas reconhecer os efeitos produzidos pela parte ou período válido do ato inconstitucional, expulsando do sistema sua parte ou período inválido". SORMANI, Alexandre. Op. Cit., p. 147.

${ }^{83}$ Sobre o assunto ensina Ana Paula Ávila: "esta ponderação tem por objeto as normas que sustentam a manutenção de efeitos e as normas que sustentam a invalidação de efeitos em face da Constituição, considerada na sua totalidade. É perguntar: manter os efeitos promove mais a Constituição do que o desfazimento? O fato é que haverá situações em que, invalidar os efeitos, seria ainda mais contrário à Constituição do que mantê-los - situações que a jurisprudência do Tribunal Constitucional Alemão deu conta de bem demonstrar no instituto da Appellentscheindung. É que, além das normas constitucionais que justificam a declaração de inconstitucionalidade de norma infraconstitucional, deve-se recorrer às normas constitucionais que tutelem/justifiquem a preservação dos efeitos produzidos. Norma e efeitos são elementos distintos, sendo, eventualmente, abrangidos por dispositivos diferentes da Constituição. A preservação do postulado da supremacia da Constituição exige uma mudança no objeto da interpretação das normas em face da Constituição: exige que se ultrapasse a análise unidirecional entre norma legal inferior e norma constitucional superior violada em favor de uma análise multidirecional entre a norma legal inferior, os efeitos por ela produzidos, e várias normas constitucionais superiores. Parte-se, assim, da análise da norma isolada para contemplar também a análise de seus efeitos, que são protegidos por outras normas. O processo de ponderação resulta do agrupamento de todas essas normas e razões de decidir, para, obedecendo ao critério da coerência, orientar o intérprete sobre a direção a ser tomada na decisão" ÁVILA, Ana Paula. Op. Cit., p. 69-70.
} 
acerca da constitucionalidade do referido artigo, este vem sendo utilizado em diversos julgados do Supremo Tribunal Federal. Analisaremos, ainda, princípios instrumentais que entendemos ser necessários à correta utilização do instrumento de modulação dos efeitos, tais como a ponderação e a proporcionalidade.

\subsection{Análise dos requisitos formais necessários à modulação de efeitos presentes no artigo 27 da Lei n. 9.868/99}

Conforme já mencionado, o artigo 27 da Lei n. 9.868 permitiu ao Supremo Tribunal Federal restringir os efeitos da declaração de inconstitucionalidade, desde que a decisão seja proferida por dois terços dos membros do Tribunal e estejam presentes razões de segurança jurídica ou de excepcional interesse social.

Primeiramente, é interessante observar que o artigo exige como requisito formal a declaração de inconstitucionalidade. Em nosso ordenamento jurídico, essa declaração pode ser obtida através da procedência de ação direta de inconstitucionalidade, bem como através da improcedência de ação declaratória de constitucionalidade, uma vez que ambas as ações possuem caráter dúplice ${ }^{84}$.

A contrario sensu, não poderiam ser modulados os efeitos das decisões de improcedência de ação direta de inconstitucionalidade e de procedência de ação declaratória de constitucionalidade ${ }^{85}$. No entanto, em

\footnotetext{
84،“As decisões definitivas de mérito (sejam pela procedência ou pela improcedência), proferidas pelo Supremo Tribunal Federal, nas ações declatórias de constitucionalidade de lei ou do ato normativo federal, produzirão eficácia contra todos e efeito vinculante, relativamente aos demais órgãos do Poder Judiciário e ao Poder Executivo. Assim, se o Supremo Tribunal Federal concluir que a lei ou ato normativo federal é constitucional, então expressamente fará a declaração, julgando procedente a ação, que produzirá efeitos ex tunc, erga omnes e vinculante a todos os órgãos do Poder Executivo e aos demais órgãos do Poder Judiciário. Da mesma forma, se considerar improcedente a ação, julgará a inconstitucionalidade ou ato normativo, os mesmos efeitos." MORAES, Alexandre de. Op. Cit., p. 706.

${ }^{85}$ Luciana de Pontes Saraiva entende que a modulação seria possível quando o Tribunal declara a constitucionalidade de uma lei em hipóteses excepcionais. SARAIVA, Luciana de Ponte. Op. Cit., p. 64 .
} 
decisão proferida na ADI 3.756, transitada em julgado em 07.12.2007, o Supremo Tribunal Federal modulou os efeitos de declaração de inconstitucionalidade julgada improcedente, fundamentando sua decisão no artigo 23 da Lei de Responsabilidade Fiscal e não no art. 27 da Lei n. 9.868/99, como seria esperado ${ }^{86}$.

Outro requisito formal presente no dispositivo em questão é a exigência de que a decisão seja proferida por dois terços dos membros do Tribunal. É necessário ressaltar que o quórum exigido pelo artigo 27 da Lei n. 9.868 diz respeito somente à modulação de efeitos, não havendo qualquer dissonância entre a norma em questão e aquela prevista no artigo 97 da Constituição, que exige o voto da maioria absoluta dos membros do Tribunal para a declaração de inconstitucionalidade de lei ou ato normativo $^{87}$.

Em relação aos requisitos materiais exigidos pelo artigo, este faz alusão a dois conceitos jurídicos indeterminados: razões de segurança jurídica e excepcional interesse social. É natural que os Tribunais se guiem por conceitos jurídicos indeterminados na tarefa de modulação de efeitos de suas decisões, uma vez que a conveniência da modulação dos efeitos da decisão é analisada no caso concreto, ponderando-se os princípios que se encontram divergentes, a fim de encontrar a solução que melhor tutela a relação jurídica em questão ${ }^{88}$.

Para que a modulação de efeitos ocorra de forma correta, sem discricionariedade, é necessário que os Ministros do Supremo Tribunal Federal "cumpram rigorosamente as regras básicas da argumentação discursiva toda vez que forem aplicar o art. 27 da Lei $n .9 .868^{\text {" } 89}$. Para que

\footnotetext{
${ }^{86}$ STF, ADI 3756 ED, Relator: Min. Carlos Britto, Tribunal Pleno, julgado em 24.10.2007, 23.11.2007.

${ }^{87}$ ÁVILA, Ana Paula. Op. Cit., p. 58.

88“"A indeterminação permite ao aplicador operar com uma margem de valoração, remetendo-o à realidade concreta da situação e permitindo-lhe buscar a solução específica para o caso além da própria norma a ser aplicada" ÁVILA, Ana Paula. Ibid., p. 78.

${ }^{89}$ GODOI, Marciano Seabra de. Op. Cit., p. 307.
} 
isso ocorra, é necessário que os julgadores evidenciem em seus votos um severero juízo de ponderação que demonstre, com base no princípio da proporcionalidade, as razões pelas quais foram modulados os efeitos de determinada decisão ${ }^{90}$. Portanto, antes de analisarmos os critérios materiais mencionados no art. 27 da Lei n. 9.868, se faz necessário tecer alguns comentários a respeito dos princípios da ponderação e proporcionalidade ${ }^{91}$.

\subsection{A ponderação de bens e a proporcionalidade como princípio instrumental na modulação de efeitos}

A ponderação ocorre quando o intérprete se vê obrigado a sopesar idéias contrárias que, no âmbito do direito, podem ser princípios, bens, interesses, etc. A técnica de ponderação ganhou força no direito constitucional, em especial no tocante aos direitos fundamentais ${ }^{92}$.

Ana Paula Ávila afirma que o processo de ponderação é estruturado em três fases distintas: (i) identificação e análise de princípios objeto de ponderação - princípios que justificam a retroatividade da decisão e aqueles que justificam sua modulação; (ii) atribuição de peso a cada princípio

\footnotetext{
90 “a argumentação do intérprete deverá ser explicitamente apresentada, em especial nos casos em que há ponderação de princípios ou normas, porque o julgador deve demonstrar qual foi o caminho percorrido para chegar a uma conclusão e não a outra". CEZAROTI, Guilherme. O consequencialismo jurídico e as modulações das decisões do STF. In. ROCHA, Valdir de Oliveira (Org.) Grandes Questões Atuais do Direito Tributário. 13 volume. São Paulo: Dialética, 2009, p. 135.

${ }^{91}$ Sobre o assunto leciona Ana Paula Ávila: “A aplicação do art. 27 exige do intérprete um importante trabalho de justificação para seu emprego, muito especialmente quando a manutenção ou o desfazimento dos efeitos de norma inconstitucional colocam em pauta os direitos fundamentais. Esse processo de justificativa envolve a identificação do objeto, ou seja, dos direitos ou interesses com os quais se está lidando quando estão em confronto normas que favorecem a invalidação ou o reconhecimento dos efeitos; e pressupõe também a identificação das razões que levam o intérprete a atribuir maior peso a uma ou outra norma. A tese que se pretende desenvolver e, devidamente, justificar pela ordem constitucional vigente, é a de que esses conceitos somente estarão adequadamente preenchidos quando, (a) no processo hermenêutico forem considerados apenas elementos da ordem normativa, afastando-se aqueles de caráter apenas político ou as considerações meramente pragmáticas; e, (b) do processo hermenêutico, resultar benefício aos direitos individuais fundamentais, sejam eles individual ou coletivamente considerados" ÁVILA, Ana Paula. Op. Cit., p. 73-74.

${ }^{92}$ Ibid., p. 91.
} 
objeto da ponderação e (iii) a prevalência de um princípio sobre os demais ${ }^{93}$.

Ana Paula de Barcellos, por sua vez, salienta que, no processo ponderativo, deve ser dada preferência às normas que promovem a dignidade da pessoa humana e os direitos fundamentais. Tal preferência decorre do tratamento dado a esses princípios em nosso sistema constitucional $^{94}$. Sobre o assunto leciona a autora:

É absolutamente tranquilo na doutrina e na jurisprudência que a Constituição fez uma opção material clara pela centralidade da dignidade da pessoa humana e, como consequência direta, dos direitos fundamentais. Essa conclusão decorre de forma muito evidente da leitura do preâmbulo, dos primeiros artigos da Carta e do status de cláusula pétrea conferido a tais direitos" ${ }^{95}$.

Em combinação com a técnica de ponderação, deve-se utilizar o postulado da proporcionalidade ${ }^{96}$. As relações estabelecidas entre o Poder Público e os cidadãos devem ser adequadas, somente ocorrendo restrições aos direitos fundamentais quando estritamente necessário ao alcance das finalidades públicas. Ana Paula Ávila conceitua a proporcionalidade com propriedade ao afirmar:

\footnotetext{
${ }^{93}$ Ibid., p. 92.

${ }^{94}$ Sobre o assunto, cabe transcrever posicionamento de Ana Paula Ávila: "A valoração constitucional dos princípios é claramente percebida através do texto e da estrutura das normas na Constituição. Uma forma segura de reconhecimento dessa hierarquia axiológica dá-se pela própria interpretação literal: basta se ater àquilo que o texto designa como fundamental e têm-se os valores para cuja proteção a argumentação haverá de convergir. Os primeiros princípios constitucionais estão vestibularmente dispostos no texto: federação, república, democracia, dignidade humana (art. $1^{\circ}$ ), tripartição do poder $\left(\operatorname{art.} 2^{\circ}\right.$ ). São nomeados princípios fundamentais, contrapondo-se, por exemplo, a meros princípios gerais da ordem econômica (arts. 170 e seguintes). (...) Do reconhecimento dessa hierarquia, importantes consequências se farão sentir no jogo de argumentos que podem ser suscitados no preenchimento dos conceitos de razões de segurança jurídica e excepcional interesse social. Isso porque essa hierarquia fornece um critério material de prevalência, que favorece a proteção dos direitos fundamentais do indivídio e da dignidade humana." Ibid., p. 128.

${ }^{95}$ BARCELlOS, Ana Paula. Ponderação, Racionalidade e Atividade Jurisdicional. Rio de Janeiro: Renovar, 2005. p. 252.

${ }^{96}$ Ana Paula Ávila critica o posicionamento de parte da doutrina que entende a proporcionalidade como um princípio. Para a Autora, a proporcionalidade possui natureza distinta dos outros princípios, uma vez que não entra em conflito com outras normas, servindo, justamente, para sopesar princípios que estejam em conflito. ÁVILA. Ana Paula, Op. Cit., p. 134-135.
} 
somente será proporcional a restrição a direito por uma medida que seja adequada para atingir o fim público, que seja a menos restritiva possível ao direito individual e cujas vantagens promovidas pelo fim visado compensem o prejuízo causado ao direito objeto de restriçãa ${ }^{97}$.

Para que possamos aplicar o postulado da proporcionalidade, devemos analisar se os meios utilizados para se alcançar um fim foram apropriados ou se há manifesta desproporção entre eles ${ }^{98}$. A análise entre meios e fins depende da utilização de três critérios que compõem o postulado da proporcionalidade: (i) adequação entre meio e fim, (ii) necessidade e (iii) proporcionalidade em sentido estrito ${ }^{99}$.

A adequação ocorrerá sempre que restar comprovado que o meio utilizado a se atingir o fim visado foi apropriado. A análise da necessidade consiste em verificar se o fim poderia ser alcançado de outra forma que não restringisse os direitos fundamentais. Por fim, a proporcionalidade em sentido estrito consiste em uma ponderação dos valores envolvidos no caso concreto, a fim de verificar se as vantagens obtidas pelo fim visado são proporcionais às desvantagens causadas pelo meio utilizado ${ }^{100}$.

Para os fins a serem alcançados pelo artigo 27 da Lei n. 9.868/99, a proporcionalidade deverá ser utilizada para determinar se a atribuição de efeitos ex nunc ou ex tunc é o meio adequado, necessário e proporcional stricto sensu para promover a Constituição e atingir melhor os fins do controle de constitucionalidade ${ }^{101}$.

\footnotetext{
${ }^{97}$ Ibid., p. 134.

${ }^{98}$ BONAVIDES, Paulo. Op. Cit., p. 393.

${ }^{99}$ Luciana de Pontes Saraiva entende que o critério da proporcionalidade em sentido estrito correponde à idéia de ponderação. Afirma a Autora: “a ponderação corresponderá exatamente à aplicação do terceiro sub-princípio, que se traduz na proporcionalidade em sentido estrito a ser desenvolvida em três etapas: a identificação da intensidade da restrição ao direito fundamental; a importância de realização do princípio antagônico ao direito restringido e; se a importância da realização do fim justifica a restrição ao direito fundamental, comparando-se, assim, os efeitos negativos e positivos deflagrados pela medida." SARAIVA, Luciana de Pontes. Op. Cit., p. 58.

${ }^{100}$ ÁVILA. Ana Paula, Op. Cit., p. 137-138.

${ }^{101}$ Ibid., p. 136.
} 


\subsection{Critério material de ponderação: interesse social relevante e segurança jurídica}

Iniciaremos o estudo dos critérios materiais de modulação de efeitos presentes no art. 27 da lei n. 9.869 com a análise do critério de interesse social relevante.

O conceito de interesse social relevante é envolto em subjetivismo, fato que vem, inclusive, sendo alvo de crítica por parte da doutrina ${ }^{102}$. No entanto, podemos afirmar que o conceito está ligado à idéia de bem comum. Alexandre Sormani, ao definir interesse social relevante afirma que este "é difuso e consiste na busca de valores relevantes à sociedade", 103.

O entendimento de que a expressão interesse social é relacionada ao bem comum já era encontrado no Direito Administrativo que, ao analisar o artigo 184 da Constituição Federal, já preceituava que os bens desapropriados para fins de interesse social se destinavam à coletividade ${ }^{104}$.

No entanto, para fins de controle de constitucionalidade, o artigo 27 da Lei n. 9.868 é o primeiro a incluir o interesse social como critério material de ponderação. A esse respeito, é interessante mencionar que o artigo em comento foi diretamente influenciado pela Constituição Portuguesa de 1976 que, em seu artigo 282, n. 4, preceituava que os efeitos das declarações de inconstitucionalidade poderiam ser modulados quando

\footnotetext{
${ }^{102}$ Sobre o assunto comenta Ana Paula Ávila: "seu conceito [de interesse social relevante] é bem mais fluido, contrastando com a própria necessidade de proteção da previsibilidade, exigida pelos ditames da segurança jurídica. Esse contraste, como se verá mais adiante, torna altamente questionável a constitucionalidade do emprego dessa expressão no art. 27, uma vez que a adoção de uma conceito, de certa forma imprevisível, viola os próprios fundamentos do princípio do Estado de Direito". Ibid., p. 88.

${ }^{103}$ SORMANI, Alexandre. Op. Cit., p. 140.

104، os bens desapropriados por interesse social não se destinam à Administração ou a seus delegados, mas sim à coletividade ou, mesmo, a certos beneficiários que a lei credencia para recebê-los e utilizá-los convenientemente". MEIRELLES, HELY LOPES. Direito Administrativo Brasileiro. 25ª ed. São Paulo: Malheiros, 2000. p. 555.
} 
houvesse razões de segurança jurídica, equidade ou interesse público de excepcional relevo ${ }^{105}$.

A melhor doutrina diferencia os conceitos de interesse público primário e secundário, sendo o primeiro conceituado como o interesse pertencente à coletividade e o segundo como um interesse particular do Estado. Dessa forma, entendemos que somente o interesse público primário estaria protegido pela expressão interesse social relevante utilizada como critério material da modulação de efeitos das decisões do Supremo Tribunal Federal.

A respeito do critério de interesse social podemos concluir que o conceito, pelo menos no tocante ao controle de constitucionalidade, ainda é novo, não existindo uma noção clara do que seria considerado interesse social relevante para fins de modulação de efeitos das decisões. No entanto, a modulação de efeitos só poderá ocorrer após um "severo juízo de ponderação que, fundado no princípio da proporcionalidade (...), faça prevalecer a segurança jurídica ou outro princípio constitucionalmente relevante que venha a assumir a forma de excepcional interesse social" 106.

O outro critério material de ponderação previsto no artigo 27 da Lei n. 9.868/99 é a segurança jurídica. A segurança jurídica deve ser considerada como direito fundamental previsto no $\operatorname{artigo} 5^{\circ}$ da

\footnotetext{
${ }^{105}$ Ana Paula Ávila, citando Rui Medeiros afirma que o dispositivo da Constituição portuguesa só utilizou a expressão "interesse público de excepcional relevo" por entender que os outros dois critérios mencionados no artigo não abarcavam todas as possibilidades de restrição de efeitos das decisões de inconstitucionalidade. A Autora afirma ainda que o termo é interpretado de forma restritiva de forma a evitar sua utilização para fins políticos. ÁVILA, Ana Paula. Op. Cit., p. 165. ${ }^{106}$ ÁVILA, Ana Paula. Op. Cit., p. 167.
} 
Constituição $^{107}$, bem como princípio constitucional imanente ao Estado de Direito $^{108}$. Sobre o assunto leciona Alexandre Sormani:

Se a norma jurídica é um todo sistêmico, e no Estado de direito a Constituição, na concepção jurídica, é a lei de superioridade hierárquica, nota-se que cumpre a esta harmonizar a ordem jurídica, conferindo validade no sistema àqueles atos a ela compatíveis e negando validade aos contrários. Logo, a segurança jurídica corresponde à estabilidade da Constituição e dos atos que a realizam. Uma Constituição em constante modificação perde eficácia social, deixa de ser confiável e, assim, abandona o nobre mister de manter a harmonia do ordenamento como um todo, gerando sua ruína. Portanto, a segurança jurídica, por natureza, é um princípio do Estado de direito" ${ }^{109}$.

Percebe-se, portanto, que a segurança está atrelada ao conceito de estabilidade e, consequentemente, à idéia de previsibilidade. A estabilidade inerente ao conceito de segurança jurídica permite ao cidadão que conheça as normas vigentes, bem como as consequências diretas de seus atos à luz dessas normas. Tal conhecimento permite que os cidadãos construam certa expectativa em torno do que pode ser esperado do Estado ${ }^{110}$.

Essa expectativa dos cidadãos em torno do comportamento que esperam do Estado diante de um caso concreto é protegida por um princípio

\footnotetext{
${ }^{107}$ Constituição Art. $5^{\text {o }}$ "Todos são iguais perante a lei, sem distinção de qualquer natureza, garantindo-se aos brasileiros e aos estrangeiros residentes no País a inviolabilidade do direito à vida, à liberdade, à igualdade, à segurança e à propriedade" Disponível em http://www.planalto.gov.br/ccivil_03/constituicao/constitui\%C3\%A7ao.htm. Acesso em 30.05.2010.

${ }^{108}$ Luís Roberto Barroso afirma que "a segurança jurídica passou a designar um conjunto abrangente de idéias e conteúdos, que incluem: "1. a existência de instituições estatais dotadas de poder e garantias, assim como sujeitas ao princípio da legalidade; 2. A confiança nos atos do Poder Público, que deverão reger-se pela boa-fé e razoabilidade; 3. A estabilidade das relações jurídicas, manifestadas na durabilidade das normas, na anterioridade das leis em relação aos fatos sobre os quais incidem e na conservação dos direitos em face da lei nova; 4. Na previsibilidade dos comportamentos, tanto os que devem ser seguidos como os que devem ser suportados; 5. A igualdade perante a lei, inclusive com soluções isonômicas para situações idênticas ou próximas" BARROSO, Luís Roberto. Temas de Direito Constitucional. Rio de Janeiro:Renovar, 2001. p. 5051.

${ }^{109}$ SORMANI, Alexandre. Op. Cit., p. 37.

${ }^{110}$ ÁVILA. Ana Paula. Op. Cit., p. 147.
} 
conhecido pela doutrina como "proteção da confiança", que possui estreita relação com o princípio da segurança jurídica ora estudado ${ }^{111}$.

O princípio da proteção da confiança, aspecto subjetivo do princípio da segurança jurídica, foi utilizado pela primeira vez pelo Tribunal Administrativo Superior de Berlim, em decisão de 14.11.1956. Neste caso, o direito ao recebimento de pensão de uma viúva de um funcionário que vivia na República Democrática Alemã foi revisto após sua mudança para a Alemanha Ocidental. A viúva alegou que o ato administrativo que concedeu o direito à pensão previa de forma expressa que a pensão continuaria a ser paga, mesmo em caso de mudança para a Alemanha Ocidental. Ocorre que, após a mudança, o ato foi revisto e passou a negar o direito anteriormente concedido. O Tribunal afirmou que a proteção da confiança no ato administrativo anterior deveria ter sido respeitada, determinando a manutenção da relação jurídica anterior ${ }^{112}$.

O princípio da proteção da confiança determina que a expectativa dos cidadãos em relação à estabilidade dos atos emitidos pelo Poder Público seja considerada no processo de ponderação a ser feito pelo julgador, em contrapartida à presunção de legitimidade dos atos normativos ${ }^{113}$. Tal princípio possui especial importância em sede de controle de constitucionalidade visto que, muitas vezes, a norma inconstitucional gera efeitos para os cidadãos, bem como presunção de legitimidade, sendo, portanto, fundamental a observância do princípio da proteção da confiança em sede de modulação de efeitos.

\footnotetext{
${ }^{111}$ A respeito dos princípios da segurança jurídica e proteção da confiança, Canotilho leciona: "Os princípios da proteção da confiança e da segurança jurídica podem formular-se assim: o cidadão deve poder confiar em que aos seus atos ou às decisões públicas sobre seus direitos, posições jurídicas e relações, praticadas ou tomadas de acordo com as normas jurídicas vigentes, se ligam os efeitos jurídicos duradouros, previstos ou calculados com base nessas mesmas normas." Apud. SILVA, Celso de Albuquerque. Cofins das Sociedades Civis de Profissão Regulamentada e o Princípio da Segurança Jurídica. Um caso de Modulação de Efeitos Temporais da Decisão a ser proferida pelo Supremo Tribunal Federal ? Revista Dialética de Direito Tributário, São Paulo, ${ }^{\circ}$ 155 ,p. 07-17, ago.2008, p. 9.

${ }^{112}$ SARAIVA, Luciana de Pontes. Op. Cit., p. 79.

${ }^{113}$ ÁVILA. Ana Paula. Op. Cit., p. 147.
} 
A proteção da confiança é comumente relacionada ao princípio da boa-fé objetiva, que deve ser igualmente observado na modulação temporal dos efeitos das decisões proferidas pelo Supremo Tribunal Federal, uma vez que, da mesma forma que o princípio da proteção da confiança, integra o princípio da segurança jurídica $^{114}$.

A boa fé objetiva nada mais é do que um dever de lealdade que deve ser respeitado por todos em suas relações recíprocas. Esse dever de lealdade exigido de toda a sociedade veda o exercício de conduta contraditória e destaca a importância da previsibilidade de comportamento que deve pautar as relações jurídicas em geral.

É importante destacar que o princípio da segurança jurídica possui um aspecto objetivo referente à irretroatividade das leis ${ }^{115}$. Sobre o assunto, comenta Luciana de Pontes Saraiva:

A vedação à retroatividade traduz-se na fórmula de garantia do direito adquirido, ato jurídico perfeito e coisa julgada, conforme artigo $5^{\circ}$, XXXVI da Constituição Federal, bem como nos princípios da irretroatividade da lei penal (artigo $5^{\circ}, \mathrm{XL}$ ) e da anterioridade tributária (art. 150, III, "a")

Por fim, voltamos a destacar que o princípio da segurança jurídica possui estreita relação com a proteção dos direitos fundamentais dos cidadãos e com o princípio da dignidade da pessoa humana, de forma que a modulação de efeitos das decisões de inconstitucionalidade deve observar estes preceitos constitucionais sempre que possível. Tal afirmação nos leva a concluir que a modulação dos efeitos, na maior parte das vezes, deverá ser

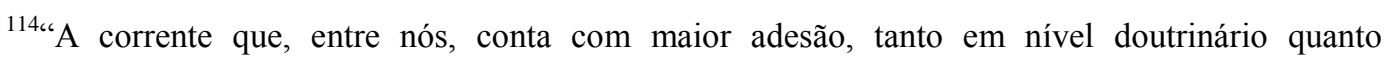
jurisprudencial, fundamenta a boa-fé no princípio de segurança jurídica, alegando que segurança jurídica e boa-fé são duas faces da mesma moeda.” Ibid., p. 156.

${ }^{115}$ Sobre o assunto, Celso Antônio Bandeira de Mello leciona: "o princípio da segurança jurídica é, provavelmente, o maior de todos os princípios fundamentais do Direito, já que se encontra na base dele, em seu ponto de partida. A irretroatividade da lei nova, os institutos da prescrição, da decadência, da preclusão, da coisa julgada, do ato jurídico perfeito e do direito adquirido, são, dentre outros, manifestações explícitas e concretas deste sumo princípio". MELLO, Celso Antonio Bandeira de. Segurança Jurídica e Mudança de Jurisprudência. Revista de Direito do Estado n.6:327-338, abr/jun de 2007, p. 329-330.

${ }^{116}$ SARAIVA, Luciana de Pontes. Op. Cit., p. 77.
} 
instituída em benefício dos cidadãos. Sobre o assunto, cabe transcrever afirmação de Ana Paula Ávila:

Questão interessante é responder se o Estado pode também invocar a segurança jurídica, nesse mesmo aspecto, para a manutenção de situações em que a lei inconstitucional tenha gerado em seu benefício. A resposta é não, taxativamente, não, por diversas razões. Primeiro, porque, se esse benefício se deu em detrimento de direitos fundamentais do indivíduo, já se concluiu pela prevalência desses em caso de conflito. Segundo, porque a segurança jurídica é, também, um direito fundamental do cidadão (art. $5^{\circ}$, caput) oponível ao Estado, e o Supremo Tribunal Federal, na esteira do pensamento constitucional germânico, tem confirmado o entendimento de que os direitos fundamentais aproveitam aos cidadãos e, não, ao Estado. E terceiro, porque uma análise mais aprofundada de alguns aspectos do princípio da boa-fé, que, por aqui, tem servido para complementar a segurança jurídica no sentido de proteção de confiança, jamais autorizaria que o autor de um ato inválido pudesse lograr proveito através dele ${ }^{117}$.

Percebe-se, portanto, que a atribuição de efeitos prospectivos às decisões de constitucionalidade, em regra, deve proteger os direitos fundamentais dos cidadãos, em detrimento do Estado. Em matéria tributária, esta observação ganha contornos próprios, visto que acarreta beneficiar os interesses dos contribuintes, em detrimento dos do Fisco, o que será analisado em capítulo próprio.

${ }^{117}$ ÁVILA, Ana Paula. Op. Cit. p. 151-152. 


\section{CAPÍTULO QUARTO \\ Modulação de efeitos no controle difuso}

\subsection{Da possibilidade de aplicação do artigo 27 da Lei $n^{\circ} 9.868 / 99$ no controle difuso de constitucionalidade}

Conforme já analisado, o artigo 27 da Lei $n^{\circ}$ 9.868/99 permitiu ao Supremo Tribunal Federal modular os efeitos de suas decisões proferidas em ação direta de inconstitucionalidade e em ação declaratória de constitucionalidade. É necessário observar que o dispositivo em comento só prevê a hipótese de modulação de efeitos das decisões proferidas em sede de controle concentrado, sendo omisso em relação à sua utilização no controle difuso.

O controle difuso de constitucionalidade, bastante influenciado pelo sistema de controle de constitucionalidade norte-americano, entende que as normas inconstitucionais são nulas desde seu nascimento, sendo a decisão que determina sua inconstitucionalidade declaratória, e não constitutiva.

Este é o entendimento adotado tanto no Brasil como nos Estados Unidos. No entanto, mesmo no sistema de controle de constitucionalidade norte-americano, este entendimento admitiu temperamentos, ocorrendo o mesmo no sistema brasileiro que, conforme mencionado, já admitia a modulação do esfeitos, inclusive em sede de modelo difuso, antes mesmo da entrada em vigor do art. 27 da Lei ${ }^{\circ}$ 9.868/99 em nosso ordenamento jurídico $^{118}$.

\footnotetext{
${ }^{118}$ A esse respeito, leciona Carlos Wagner Dias Ferreira: "Independentemente do modelo consagrado de controle de constitucionalidade (difuso ou concentrado), sempre se há de indagar a respeito dos prováveis efeitos que a decisão declaratória de inconstitucionalidade pode repercutir na resolução do caso particular. A idéia de que o controle abstrato melhor se compatibiliza com a teoria da anulabilidade, e o concreto, com o da nulidade, não resiste a qualquer análise científica profunda acerca das teorias que a respaldam, uma vez que é inegável que, em ambos os regimes, indistintamente, a incidência dos efeitos retrospectivos pode se mostrar mais nociva ao Direito e à
} 
Dessa forma, ainda que o art. 27 da Lei n ${ }^{\circ}$ 9.868/99 não mencione de forma expressa a possibilidade de modulação de efeitos em sede de controle difuso, não nos parece razoável afirmar que a modulação em tais casos não possa ocorrer $^{119}$. A necessidade de modulação de efeitos pode ocorrer também em sede de controle difuso, uma vez que "o que efetivamente suscita a necessidade de superação da regra ex tunc são as normas constitucionais que tutelam a manutenção das situações geradas pela norma inconstitucional" ${ }^{120}$. Ou seja, a possibilidade de modulação de efeitos decorre de uma situação em que um princípio constitucional é contrastado pelos princípios da boa-fé e da segurança jurídica, devendo estes últimos prevalecer de forma a evitar uma decisão desproporcional, o que pode ocorrer tanto em sede de controle concentrado como difuso ${ }^{121}$.

A jurisprudência do STF vem promovendo a modulação de efeitos de suas decisões, inclusive em controle difuso. Sobre o assunto, destacamos

ordem jurídica do que a própria ofensa à Constituição.”. FERREIRA, Carlos Wagner Dias. Modulação dos efeitos da declaração de inconstitucionalidade no controle difuso. Disponível em http://www.jfpe.gov.br/biblioteca/juizes/carlos_wagner_esmafe12_p155-178.pdf. Acesso em 10.05.2010.

${ }^{119}$ A doutrina é divergente em relação à possibilidade de modulação de efeitos no controle difuso. Sobre o assunto, menciona Ana Paula Ávila: "Pela aplicação da modulação dos efeitos apenas no controle abstrato de constitucionalidade: ARAGÃO, Alexandre Santos. O Controle de Constitucionalidade pelo Supremo Tribunal Federal à luz da teoria dos poderes neutrais. Revista Forense, v. 373, p. 24-27, mai/jun 2004. STRECK, Lenio Luiz. Jurisdição Constitucional e Hermenêutica. Rio de Janeiro: Forense, 2004, p. 693-698. CASTRO, Carlos Roberto Siqueira. Da declaração de inconstitucionalidade e seus efeitos em face das Leis $n^{\circ}$ 9.868/99 e 9.882/99. In: SARMENTO, Daniel (org.). O controle de constitucionalidade e a Lei $n^{\circ} 9.868$ de 1999. Rio de Janeiro, Lumen Juris, 2001, p.39-99. Para a modulação dos efeitos no controle abstrato e também no concreto: MENDES, Gilmar. Jurisdição Constitucional. São Paulo: Saraiva, 2004, p. 365/368. MEDEIROS, Rui. A decisão de inconstitucionalidade. Lisboa: Universidade Católica, 1999, p. 743. ROSSI, Júlio César. A reforma do judiciário e suas implicações nos modelos concentrado e difuso de controle de constitucionalidade. In: Revista Dialética de Direito Processual, n. 31, p. 51 71, out, 2005" Apud. ÁVILA, Ana Paula. Op. Cit., p. 59-60.

${ }^{120}$ ÁVILA, Ana Paula. Op. Cit., p. 60.

${ }^{121} \mathrm{~A}$ esse respeito, é interessante transcrever entedimento de Octavio Campos Fischer sobre o assunto: "Em princípio, por força do advento do art. 27 da Lei n 9.868/99, pode-se até pensar que a manipulação dos efeitos somente seja admitida ou, ao menos, seja mais adequada no campo do controle abstrato. Ao contrário, porém, pensamos que será o controle difuso o local mais apropriado para que tal ocorra. Afinal, será na análise das situações concretas que se apresentam ao Poder Judiciário que este poderá verificar se, e em que medida, de fato, estão presentes outros valores, que não só o princípio da constitucionalidade em sentido estrito. Será, então, na análise do caso concreto que o Judiciário poderá sopesar a boa-fé, a segurança jurídica, a igualdade para melhor concluir pela restrição dos efeitos" FISCHER, Octavio Campos. Os efeitos da declaração de inconstitucionalidade no Direito Tributário Brasileiro. Rio de Janeiro: Renovar, 2004, p. 307. 
o acórdão proferido no RE $197.917^{122}$ no qual foi declarada incidentalmente a inconstitucionalidade da legislação do Município de Mira Estrela, que havia fixado o número de legisladores em desconformidade com a Constituição Federal, e determinada a modulação dos efeitos da referida decisão para que o critério de fixação do número de vereadores contido no acórdão fosse aplicado pelo Município no pleito eleitoral seguinte ${ }^{123}$.

No mesmo sentido, se manifestaram os ministros do STF no julgamento do HC 82.959 $9^{124}$, no qual foi estabelecida a modulação de efeitos da decisão de inconstitucionalidade de dispositivo da legislação federal que determinava o cumprimento das penas por crimes hediondos em regime fechado ${ }^{125}$.

Alguns acórdãos isolados proferidos pelo Supremo Tribunal Federal (RE n 430.421 AgR, Relator Min. Cezar Peluzo, julgado em 30.11.2004, DJ 04.02.2005, AI n 521.546 AgR-ED, Relator Min. Sepúlveda Pertence, julgado em 26.04.2005, DJ 13.05.2005 e AI n 478.398 AgR-ED, Relator Min. Eros Grau, julgado em 22.06.2005, DJ 05.08.2005) afirmam não poder se aplicar o efeito ex tunc à declaração de inconstitucionalidade proferida em controle difuso ${ }^{126}$. No entanto, a modulação de efeitos vem sendo praticada constantemente, não havendo motivo para que seja afastada em sede de controle difuso, desde que as exigências impostas pelo art. 27 da Lei $n^{\circ} 9.868 / 99$ sejam cumpridas ${ }^{127}$.

\footnotetext{
${ }^{122}$ STF, RE 197917, Relator Min. Maurício Corrêa, Tribunal Pleno, julgado em 06.06.2002, DJ 07.05.2004.

${ }^{123}$ GODOI, Marciano Seabra de. Op. Cit., p. 305.

${ }^{124}$ STF, HC 82959, Relator Min. Marco Aurélio, Tribunal Pleno, julgado em 23.02.2006, DJ 01.09.2006.

${ }^{125}$ GODOI, Marciano Seabra de. Op. Cit., p. 306.

${ }^{126}$ Em relação aos precedentes mencionados, é interessante observar que em nenhum deles consta a razão pela qual não se considera possível a aplicação do art. 27 no âmbito do controle difuso. ÁVILA, Ana Paula. Op Cit., p. 59.

${ }^{127} \mathrm{~A}$ esse respeito, é importante destacar que existem doutrinadores que entendem que a modulação de efeitos em sede de controle difuso, para ser legítima, deverá observar o quórum legal de dois terços dos membros da Corte constante no art. 27 da Lei n ${ }^{\circ}$ 9.868/99, de forma que será sempre do Plenário do Supremo Tribunal Federal a competência para a modulação de efeitos
} 
Sobre a possibilidade de modulação de efeitos em sede de controle difuso, é necessário destacar que a Lei n 11.417/2006, em seu artigo $4^{\circ}$, prevê de forma expressa a possibilidade de modulação de efeitos das súmulas vinculantes editadas pelo Supremo Tribunal Federal, afastando, de uma vez por todas, o entendimento de que a modulação de efeitos não seria cabível em sede de controle difuso ${ }^{128}$.

\subsection{Da possibilidade de modulação de efeitos em casos de mudança de jurisprudência}

Analisada a possibilidade de modulação de efeitos em sede de controle concentrado e difuso, é necessário observar a hipótese de modulação de efeitos em caso de mudança de jurisprudência.

Verifica-se uma forte tendência no direito brasileiro em conferir força aos precedentes judiciais. A esse respeito, afirma Luís Roberto Barroso: "A atitude geral de observância da jurisprudência é positiva por promover valores relevantes, como segurança jurídica, isonomia e eficiência" 129 . Deve-se destacar que os precedentes judiciais, ainda que venham se fortalecendo no direito brasileiro, não são imutáveis, sendo

de decisões proferidas em sede de controle de constitucionalidade. GODOI, Marciano Seabra de. Op. Cit., p. 306.

Nesse sentido, cabe transcrever ementa proferida no AI-AgR 655.047-RJ: CONSTITUCIONAL. TRIBUTÁRIO. IPTU DO MUNICÍPIO DO RIO DE JANEIRO. PROGRESSIVIDADE ANTERIOR À EC 29/2000. TAXA DE COLETA DE LIXO E LIMPEZA PÚBLICA - TCLLP E TAXA DE ILUMINAÇÃO PÚBLICA - TIP. EFEITOS DA DECLARAÇÃO DE INCONSTITUCIONALIDADE NO CONTROLE DIFUSO. MULTA. AGRAVO IMPROVIDO. I - A atribuição de efeitos prospectivos à declaração de inconstitucionalidade, dado o seu caráter excepcional, somente tem cabimento quando o tribunal manifesta-se expressamente sobre o tema, observando-se a exigência de quorum qualificado previsto em lei. II - Aplicação de multa. III Agravo Regimental improvido. (AI 655047 AgR, Relator(a): Min. RICARDO LEWANDOWSKI, Primeira Turma, julgado em 27.05.2008, DJe-107 DIVULG 12.06.2008 PUBLIC 13.06.2008 EMENT VOL-02323-08 PP-01504).

${ }^{128}$ Art. $4^{0}$ A súmula com efeito vinculante tem eficácia imediata, mas o Supremo Tribunal Federal, por decisão de $2 / 3$ (dois terços) dos seus membros, poderá restringir os efeitos vinculantes ou decidir que só tenha eficácia a partir de outro momento, tendo em vista razões de segurança jurídica ou de excepcional interesse público. Disponível em http://www.planalto.gov.br/ccivil/_Ato2004-2006/2006/Lei/L11417.htm. Acesso em 30.05.2010.

${ }_{129}$ BARROSO, Luís Roberto. O controle de constitucionalidade no Direito Brasileiro. ${ }^{a}$ ed. São Paulo:Saraiva, 2009, p. 77. 
frequente no Supremo Tribunal Federal a modificação de precedentes judiciais há muito consolidados. É necessário advertir que esta modificação de precedente deve ser sempre realizada de forma a respeitar a segurança jurídica, as expectativas de direito geradas, a boa-fé e a confiança dos jurisdicionados $^{130}$.

A modificação de um precedente judicial do Supremo Tribunal Federal, especialmente em casos nos quais o entendimento alterado foi considerado pacífico por longo período, pode vir a trazer graves consequências aos jurisdicionados, razão pela qual a atribuição de efeitos prospectivos vem sendo utilizada com frequência nesses casos ${ }^{131}$.

A esse respeito, ressaltamos a decisão proferida pelo STF acerca de fidelidade partidária ${ }^{132}$. No caso em questão, o Partido da Social Democracia Brasileira (PSDB) impetrou mandado de segurança contra ato do Presidente da Câmara dos Deputados que indeferiu requerimento no sentido de declarar a vacância de mandatos exercidos por Deputados Federais que se desfiliaram do partido, por entender que a hipótese não figurava situação compreendida no parágrafo primeiro, do artigo 239, do Regimento Interno da Câmara dos Deputados ${ }^{133}$.

O Supremo Tribunal Federal deferiu o writ sob o argumento de que a vinculação entre o partido político e o candidato prolonga-se depois da eleição, sendo a infidelidade partidária ofensa ao princípio democrático e ao

\footnotetext{
${ }^{130}$ Ibid., p. 78.

${ }^{131}$ Sobre o assunto leciona Luis Roberto Barroso: “A atribuição de efeitos meramente prospectivos à mudança de orientação jurisprudencial deverá ser especialmente considerada nos casos em que o entendimento que está sendo alterado tornou-se pacífico por longo período. É que uma nova interpretação tende a produzir efeitos práticos semelhantes aos que decorrem da edição de lei nova. Vale dizer: embora não haja uma alteração formal do Direito vigente, verifica-se uma alteração substancial. Diante de tal situação, o valor a ser promovido com a nova orientação deverá ser ponderado com outros valores, como a boa-fé, a proteção da confiança e a segurança jurídica" Ibid., p. 79.

${ }^{132}$ STF, MS 26603, Relator: Min. Celso de Mello, Tribunal Pleno, julgado em 04.10.2007, DJe241 DIVULG 18.12.2008 PUBLIC 19.12.2008.

${ }^{133}$ SARAIVA, Luciana de Pontes. Op. Cit., p. 104/108.
} 
exercício legítimo de poder. Dessa forma, restou-se defendido o entendimento de que a perda de mandato eletivo em caso de infidelidade partidária pode ser extraída da Constituição, ainda que não prevista expressamente em lei.

Ocorre que a decisão em comento acabou por alterar entendimento jurisprudencial do Supremo Tribunal Federal, que havia se solidificado no sentido de considerar inaplicável o princípio da fidelidade partidária aos parlamentares empossados. Dessa forma, o STF acabou por modular os efeitos de sua decisão, considerando como marco do início da eficácia de seu pronunciamento a data de decisão proferida pelo Tribunal Superior Eleitoral ao apreciar a consulta 1.398/DF, na qual foi reconhecido o direito de preservação das vagas obtidas pelo sistema eleitoral proporcional pelos partidos políticos na hipótese discutida no mandado de segurança em referência.

Outro caso em que foi determinada a modulação de efeitos de decisão na qual houve mudança de entendimento jurisprudencial ocorreu no julgamento do Conflito de Competência 7204/MG ${ }^{134}$. Neste caso, o STF modificou sua interpretação a respeito do artigo 109, inciso I, da Constituição Federal, passando a entender, a partir de 2005, que a competência para o julgamento de ações indenizatórias decorrentes de acidentes de trabalho seria da Justiça do Trabalho e não mais da Justiça comum. No entanto, a decisão em referência ressalvou que o novo entendimento não alcançaria os processos julgados pela Justiça Estadual até então, somente passando a ser adotado com o advento da Emenda Constitucional n. 45.

\footnotetext{
${ }^{134}$ STF, CC 7204, Relator: Min. Carlos Britto, Tribunal Pleno, julgado em 29.06.2005, DJ 09.12.2005.
} 
Percebe-se, portanto, que nos casos mencionados, mesmo não havendo declaração de inconstitucionalidade, mas somente uma mudança de entendimento jurisprudencial, a atribuição de eficácia prospectiva restouse não só possível, como necessária à manutenção do interesse público e da segurança jurídica. A esse respeito leciona Luis Roberto Barroso:

Com efeito, se na hipótese extrema de reconhecimento da inconstitucionalidade de uma lei o STF admite a possibilidade de não se dar à decisão efeitos retroativos, com muito mais razão deverá admiti-la no desempenho da jurisdição ordinária, que não envolve a declaração de nulidade de qualquer norma em face da Constituição. Portanto, os mesmos elementos de ponderação a serem levados em conta nos casos de inconstitucionalidade deverão ser considerados aqui ${ }^{135}$.

Assim, embora o artigo 27 não seja explícito a respeito da possibilidade de modulação de efeitos em relação à mudança de jurisprudência, não há dúvidas de que a mens legis do dispositivo legal restará atendida se a técnica de modulação for estendida a essa hipótese ${ }^{136}$.

\footnotetext{
${ }^{135}$ BARROSO, Luis Roberto. Mudança da jurisprudência do Supremo Tribunal Federal em matéria tributária. Segurança Jurídica e modulação dos efeitos temporais das decisões judiciais. Revista de Direito do Estado n. 2: 261-288/abr/jun. 2006. p. 267.

${ }^{136}$ Sobre o assunto, é interessante observar entendimento de Luis Roberto Barroso: "Em se tratando de modulação por mudança de jurisprudência, data maxima venia, não há que se falar na aplicação do art. 27 da Lei $\mathrm{n}^{\circ} 8.868 / 99$ e, por consequencia, no quorum de dois terços nele previsto.". Id. Modulação dos efeitos temporais de decisão que altera jurisprudência consolidada. Quorum de deliberação. Disponível em http://www.oab.org.br/arquivos/pdf/Geral/Cofins.pdf. Acesso em 24.05.2010.
} 


\section{CAPÍTULO QUINTO \\ Modulação de efeitos no âmbito tributário}

\subsection{Análise da norma tributária: a norma impositiva e a norma exonerativa}

Estabelecidos os parâmetros gerais que vêm deteminando a modulação de efeitos das decisões proferidas pelo Supremo Tribunal Federal em nosso sistema constitucional, resta analisar os efeitos dessas decisões em âmbito tributário. No entanto, antes de começar um estudo acerca da modulação de efeitos das decisões proferidas pelo STF em âmbito tributário, é necessário analisar a norma tributária em si.

Para fins do presente estudo, classificaremos a norma tributária em dois grupos: a norma tributária impositiva e a norma tributária exonerativa ${ }^{137}$. A norma impositiva impõe um dever ao seu destinatário. No âmbito do direito tributário, o dever imposto ao contribuinte poderá ser entendido como a obrigação de pagar determinada quantia ao Estado ou uma obrigação de fazer. A norma tributária exonerativa, por sua vez, ao invés de impor um dever jurídico, prescreve uma exoneração, impedindo o surgimento de uma obrigação tributária ou determinando uma redução da carga tributária.

Dessa forma, as decisões de inconstitucionalidade em âmbito tributário podem declarar como inconstitucional a norma tributária impositiva, hipótese na qual a decisão levará à inconstitucionalidade da norma que instituiu o tributo ou o majorou, como também podem declarar como inconstitucional as normas tributárias exonerativas, excluindo do ordenamento benefício então existente.

\footnotetext{
${ }^{137}$ COÊLHO, Sacha Calmon Navarro. Teoria Geral do Tributo, da Interpretação e da Exoneração Tributária. 3 ed. São Paulo: Dialética, 2003, p. 83-89 e 199-206.
} 
Em ambas as hipóteses, a exclusão da norma do ordenamento jurídico pode acarretar injustiças, razão pela qual analisaremos, em seguida, a possibilidade de concessão de efeitos prospectivos às decisões proferidas em sede de controle de constitucionalidade em casos de declaração de inconstitucionalidade de normas tributárias impositivas e exonerativas.

\subsection{A modulação de efeitos nas declarações de inconstitucionalidade de normas impositivas}

O sistema tributário nacional é regulamentado por uma série de normas e princípios constitucionais que regem as relações entre os entes tributantes e os contribuintes, fazendo com que o sistema tributário brasileiro seja bastante rígido, uma vez que possui limitações expressamente previstas na Constituição em relação às competências para tributar conferidas à União, Estados e Municípios ${ }^{138}$.

Mesmo possuindo regras bastante claras, muitas vezes o legislador atua de forma a ultrapassar os limites de sua competência legal, instituindo ou majorando tributos de forma inconstitucional. Tais normas impositivas instituídas em desrespeito aos limites constitucionais acabam por repercutir nas relações entre os contribuintes e os entes tributantes, que guiam seus comportamentos com base na norma inconstitucional criada.

É nesse contexto que se faz necessária a análise dos efeitos da declaração de inconstitucionalidade de normas impositivas e a possibilidade de atribuição de efeitos prospectivos às decisões que declaram esta inconstitucionalidade.

\footnotetext{
${ }^{138}$ SILVA, Sérgio André R.G. da. Comentários acerca dos Efeitos da Decisão Proferida no Âmbito do Controle Abstrato da Constitucionalidade das Normas Tributárias. Revista Dialética de Direito Tributário São Paulo, n. 83, p. 150-167, ago.2002,. p. 158.
} 
Conforme já mencionado, o legislador pátrio estabeleceu, no artigo 27 da Lei n. 9.868/1999, a possibilidade de modulação de efeitos da decisão de inconstitucionalidade quando a atribuição de efeitos retroativos importe em ofensa ao princípio da segurança jurídica e ao excepcional interesse social.

No caso de declaração de inconstitucionalidade de norma tributária impositiva, a ofensa ao princípio da segurança jurídica ocorrerá quando o tributo for criado em violação aos princípios constitucionais tributários, o que irá contra a expectativa dos contribuintes de que nenhum tributo pode ser criado em desrespeito aos princípios constitucionais, tais como, a legalidade tributária, a irretroatividade e a anterioridade.

Destacamos que a criação de tributo inconstitucional viola também o excepcional interesse social, uma vez que não existe interesse social na instituição de tributos que criem uma situação de desconfiança e desrespeito aos princípios constitucionais.

Dessa forma, para que seja determinada a modulação dos efeitos de uma decisão que declare inconstitucional norma tributária impositiva, devem ser ponderados os princípios que justificam a retroatividade da decisão e aqueles que justificam sua modulação ${ }^{139}$.

Dentre os motivos frequentemente apontados pelo Fisco como ensejadores da modulação de efeitos em caso de declaração de inconstitucionalidade de norma impositiva estão as razões de interesse fiscal. De acordo com o Fisco, a modulação nesses casos se faz necessária

\footnotetext{
${ }^{139}$ A esse respeito, é importante observar que a possibilidade de ponderação de valores e bens jurídicos constitucionais não depende de previsão legal e vem sendo utilizada pelo STF antes mesmo da entrada em vigor do art. 27 da Lei n. 9.868/99. Dessa forma, ainda que o dispositivo em questão mencione expressamente somente a segurança jurídica e o excepcional interesse social, não há óbice para que a modulação de efeitos de decisões referentes a normas tributárias se paute em outros princípios constitucionais não previstos no artigo.
} 
por motivo de segurança jurídica, visto que muitas vezes a norma passou longo período sem ser contestada, e também em razão de excepcional interesse social, uma vez que a declaração de inconstitucionalidade com efeitos retroativos poderia causar prejuízo finaceiro ao ente tributante. Tais argumentos são utilizados, principalmente, em casos nos quais a declaração de inconstitucionalidade da norma acaba por conferir aos contribuintes direito à repetição de indébito do tributo declarado inconstitucional.

Passemos a analisar os argumentos fazendários de forma detalhada. Caso a lei inconstitucional tenha sido observada por longo período sem questionamento, tal fato não implica na atribuição de efeitos prospectivos à decisão em decorrência do princípio da segurança jurídica. Isto porque, em matéria tributária, o contribuinte possui prazo de 5 anos ${ }^{140}$ para reaver tributos recolhidos indevidamente. Decorrido esse prazo, extingue-se a pretensão à repetição de indébito. Sobre o assunto afirma Ricardo Augusto Saavedra Hurtado:

Conferir maior proteção do que este próprio instituto secular seria admitir a não efetividade integral do princípio protegido pela declaração de inconstitucionalidade, o que não encontra guarida no princípio da proporcionalidade. A realidade é que, o contribuinte, no ordenamento jurídico brasileiro, vendo desrespeitado algum direito no âmbito tributário, pode desde logo insurgir-se contra tal violação. É nesse momento (a violação de seu direito) em que nasce sua pretensão (teoria da actio nata), e, caso permaneça inerte por longo período (cinco anos, de acordo com o art. 168, CTN, combinado com o art. $3^{\circ}$ da Lei Complementar 118/2005), perderá a pretensão. Com tal instituto, protegem-se ambos os princípios: aquele tutelado pela declaração de inconstitucionalidade, bem como o da segurança jurídica ${ }^{141}$.

A respeito do argumento de prejuízo financeiro ao ente tributante, duas são as motivações utilizadas para alegar a necessidade de modulação de efeitos. A primeira utiliza como argumento a embasar a modulação de efeitos o fato de que toda a arrecadação obtida com o tributo

\footnotetext{
${ }^{140}$ Art. 168 do CTN c/c art. $3^{\circ}$ da Lei Complementar n. 118/2005.

${ }^{141}$ HURTADO. Ricardo Augusto Saavedra. Op. Cit., p. 39-40.
} 
inconstitucional é utilizada em prol dos contribuintes. A segunda seria o prejuízo ao Erário decorrente das ações de repetição de indébito às quais teriam direito os contribuintes após a declaração de inconstitucionalidade da norma.

Tais argumentos não podem ser considerados para fins de modulação de efeitos de decisão declarada inconstitucional. Primeiramente, é de se destacar que estas "razões de Estado" não podem de forma alguma ser aceitas em detrimento de argumentos jurídicos pautados em normas constitucionais. Sobre o assunto, já se manifestou o Supremo Tribunal Federal. Confira-se:

(...) Razões de Estado não podem ser invocadas para justificar o descumprimento da Constituição. É preciso advertir que as razões de Estado - quando invocadas como argumento de sustentação da pretensão jurídica do Poder Público ou de qualquer outra instituição - representam expressão de um perigoso ensaio destinado a submeter, à vontade do Príncipe (o que é intolerável), a autoridade hierárquico-normativa da própria Constituição da República, comprometendo, desse modo, a idéia de que o exercício do poder estatal, quando praticado sob a égide de um regime democrático, está permanentemente exposto ao controle social dos cidadãos e à fiscalização de ordem jurídico-constitucional dos magistrados e Tribunais ${ }^{142}$.

Dessa forma, deve prevalecer a repetição de indébito quando um tributo é declarado inconstitucional, pois "se a coletividade se beneficiou em detrimento do patrimônio de determinado contribuinte, esta mesma coletividade deve suportar o ônus de recompor o que foi indevidamente arrecadado" ${ }^{143}$.

A modulação de efeitos em caso de declaração de inconstitucionalidade de norma impositiva não pode ser aplicada em detrimento dos interesses dos contribuintes, visto que o Estado não pode se

\footnotetext{
${ }^{142}$ STF, $2^{\mathrm{a}}$ Turma, AI 241397 AgR, rel. Min. Celso de Mello, j. 10.08.1999, DJU 17.09.1999, p. 47.

${ }^{143}$ CEZAROTI, Guilherme. O consequencialismo jurídico e as modulações das decisões do STF. In: Grandes Questões Atuais do Direito Tributário. $13^{\circ}$ volume. Coord. Valdir de Oliveira Rocha. São Paulo: Dialética, p. 146.
} 
esquivar de arcar com sua responsabilidade em caso de decisões desfavoráveis, locupletando-se às custas dos contribuintes ${ }^{144}$.

A esse respeito, é importante destacar que a restituição dos tributos indevidamente cobrados aos contribuintes não acarreta, necessariamente, prejuízo ao Erário visto que a própria Constituição prevê meios para fazer frente a uma necessidade emergencial de recursos, tais como a utilização de medida provisória (art. 62, caput, c/c art. 167, § $3^{\circ}$, da Constituição Federal) e a criação de empréstimos compulsórios (art. 148, I e II, da Constituição Federal). É necessário destacar que medidas menos extremas, como a devolução dos valores de forma parcelada (art. 100, da Constituição Federal c/c art. 78 da ADCT, em redação dada pela Emenda Constitucional n. 30/2000), também poderiam ser tomadas, de forma a garantir tanto o direito à restituição dos contribuintes quanto a continuidade do Estado ${ }^{145}$.

\footnotetext{
${ }^{144}$ Sobre o assunto, é interessante transcrever trecho de manifestação do Ministro Celso de Mello no julgamento da Questão de Ordem da ADIn n. 534-1-DF no qual foi afirmado que o direito à restituição/compensação de valores decorrente da inconstitucionalidade de lei que cria ou majora tributos decorre da responsabilidade objetiva do Estado: "Com efeito, a elaboração teórica em torno da responsabilidade civil do Estado por atos inconstitucionais tem reconhecido o direito de o indivíduo, prejudicado pela ação normativa danosa do Poder Público, pleitear, em processo próprio, a devida indenização patrimonial. A orientação da doutrina, desse modo, tem-se fixado, na análise desse particular aspecto do tema, no sentido de proclamar a plena submissão do Poder Público ao dever jurídico de reconstituir o patrimônio dos indivíduos cuja situação pessoal tenha sofrido agravos motivados pelo desempenho inconstitucional da função de legislar. (...) declarada uma lei inválida ou inconstitucional por decisão judiciária, um dos efeitos da decisão deve ser logicamente o de obrigar a União, Estado ou Município, a reparar o dano causado ao indivíduo, cujo direito fora lesado, quer restituindo-se-lhe aquilo que indevidamente foi exigido do mesmo, como sucede nos casos de impostos, taxas ou multas inconstitucionais, quer satisfazendo-se os prejuízos, provadamente sofridos pelo indivíduo com a execução da lei suposta". Apud. TAVARES, Alexandre Macedo. A responsabilidade estatal pelo desempenho irregular da função de legislar como engrenagem do sistema de freios e contrapesos à possibilidade de o STF atribuir eficácia prospectiva às decisões de inconstitucionalidade em matéria tributária. Revista Dialética de Direito Tributário, São Paulo, n. 159, p. 07-18, dez.2008, São Paulo, p. 11.

${ }^{145}$ No mesmo sentido leciona Octávio Campos Fischer: "Neste caso, o Judiciário, por exemplo, deve levar em consideração que há múltiplas formas do poder público recuperar-se financeiramente da obrigação de restituir o que os contribuintes pagaram a mais (por exemplo, ainda que seja uma medida não muito popular, aumentar temporariamente a carga tributária). Pode-se, inclusive, determinar que a devolução, a todos os contribuintes, seja feita de forma menos onerosa ao Poder Público (em várias parcelas, por exemplo). Portanto, somente quando esgotadas todas estas possibilidades e, mesmo assim, verificar-se uma situação de prejuízo irreversível, é que o Judiciário estará legitimado a dizer que os contribuintes não têm direito à total devolução do que pagaram a título de determinado tributo. Como se vê, construímos um raciocínio que dificulta em muito a restrição dos efeitos da decisão de inconstitucionalidade em matéria tributária." FISCHER, Octávio Campos. Os efeitos da declaração de inconstitucionalidade no direito tributário brasileiro. Rio de Janeiro: Renovar, 2004. p. 260.
} 
Ademais, caso fosse modulado os efeitos de uma decisão com base em argumentos meramente arrecadatórios, tal conduta representaria incentivo à desobediência constitucional pelo legislador tributário. Sobre o assunto, é válido transcrever as palavras do Ministro Sepúlveda Pertence em julgamento da ADIN 1102-DF:

(...) certa vez, fui consultado por técnicos de determinado setor governamental sobre uma proposta de decreto-lei. Lembro-me ter dito: - este decreto não passa pelo primeiro juiz de plantão: a inconstitucionalidade é bradante. A resposta foi mais ou menos assim: quem somos nós, Dr. Procurador, para discutir a questão de inconstitucionalidade com V. Exa? Mas, veja, V. Exa. o que está ocorrendo com a questão constitucional " $x$ ": há quatro anos, a União não teve sequer uma sentença, de qualquer instância, a seu favor; no entanto - dizia-se o técnico - , a arrecadação real está por volta de $85 \%$ do previsto, porque a grande maioria não vai a juízo. Sobretudo com os pequenos tributos é o que sucede, de tal modo que grande é o risco de estimular aventuras, se se asseverar, mais ou menos na linha de princípio, que leis tributárias só se declararão inconstitucionais com efeitos $e x$ nunc: aí, provavelmente, a questão já estará morta" ${ }^{246}$.

No mesmo sentido, leciona Ronaldo Redenschi:

(...) de conferir enorme poder ao Estado que, como único ente dotado da competência para produção legislativa, poderia valer-se desta faculdade, deste "manto de presunção de constitucionalidade" e da certeza de impossibilidade de retroatividade dos efeitos produzidos por aquela lei inconstitucional para agir em sua própria torpeza, editando leis sabidamente inconstitucionais, a fim de aproveitar-se temporariamente dos efeitos patrimoniais que a mesma causaria sobre a vida e o patrimônio dos jurisdicionados ${ }^{147}$.

Dessa forma, as decisões de inconstitucionalidade de normas tributárias impositivas não podem ter seus efeitos modulados, sob risco de afronta aos princípios da legalidade, moralidade, boa-fé e proibição do enriquecimento sem causa, disposições constitucionais que garantem os direitos fundamentais dos contribuintes ${ }^{148}$. Sobre o assunto, conclui Saul Tourinho Leal:

\footnotetext{
${ }^{146}$ STF, ADI 1102, Relator: Min. Maurício Corrêa, Tribunal Pleno, julgado em 05.10.1995, DJ 17.11.1995.

${ }^{147}$ Apud. LEAL, Saul Tourinho. Modular para não pagar: a adoção da doutrina prospectiva negando direito aos contribuintes. Revista Dialética de Direito Tributári, São Paulo, n. 158, p. 7886, nov.2008. p. 84.

${ }^{148}$ Sobre o assunto, afirma Paulo Roberto Lyrio Pimenta: "Os fundamentos da repetição de indébito na hipótese trazida à colação são os princípios da legalidade, da moralidade, da boa-fé, da nulidade da norma inconstitucional e da proibição do enriquecimento sem causa. O princípio da
} 
(...) se o instituto da modulação dos efeitos da declaração de inconstitucionalidade for utilizado em desfavor dos direitos fundamentais dos contribuintes, caminharemos, todos, para a nulificação da relevante conquista jurídica esboçada pelos princípios constitucionais tributários ${ }^{149}$.

Percebe-se, portanto, que, ao ponderar os princípios constitucionais envolvidos em casos de declaração de inconstitucionalidade de norma impositiva, as alegações em prol da modulação dos efeitos trazidas pelo Fisco não são suficientes para afastar os direitos fundamentais dos contribuintes.

\subsection{A modulação de efeitos nas declarações de inconstitucionalidade de normas exonerativas}

A declaração de inconstitucionalidade de norma tributária exonerativa ocorre geralmente em duas situações: (i) quando a norma é considerada inconstitucional por violação ao princípio da isonomia e (ii) quando a norma é considerada inconstitucional por violação de norma/ princípio constitucional ou inobservância do iter procedimental previsto.

Em caso de declaração de inconstitucionalidade por violação do princípio da isonomia, esta geralmente decorre do "reconhecimento de que determinado grupo não recebeu o mesmo tratamento que o grupo inicialmente previsto na norma exonerativa" 150.

\footnotetext{
legalidade, no sentido de legalidade constitucional, significa que o legislador ordinário, ao criar a norma impositiva, deverá observar a Constituição. (...) a apropriação pelo ente tributante de valores recolhidos com base em norma inválida viola o princípio da moralidade, porque importa no descumprimento de princípios éticos, segundo os quais ninguém deve se apropriar de prestação indevida. (...) A não restituição do tributo, na hipótese sob exame, importa, outrossim, em admitir a atuação do fisco de forma desleal perante o administrado, descumprindo o princípio da boa-fé. (...) Na hipótese em estudo, evidencia-se, ademais, a presença dos requisitos necessários à aplicação do princípio da proibição do enriquecimento sem causa: empobrecimento do contribuinte aliado ao enriquecimento do Estado, derivado de norma inváilda. (...) $\mathrm{O}$ direito à restituição de tributos na situação em tela pressupõe, por fim, a pronúncia de nulidade da norma impositiva tributária,e, por conseguinte, a eficácia ex tunc da decisão. PIMENTA, Paulo Roberto Lyrio. Efeitos da decisão de inconstitucionalidade em direito tributário. São Paulo: Dialética, 2002. p. 126.

${ }^{149}$ LEAL, Saul Tourinho. Op. Cit., p. 81.

${ }^{150}$ HURTADO, Ricardo Augusto Saavedra. Op. Cit. p. 45
} 
$\mathrm{Na}$ Alemanha, como visto anteriormente, tal hipótese justifica a aplicação da técnica de declaração de inconstitucionalidade sem pronúncia de nulidade, solução que nos parece ser a melhor aplicável ao caso.

Como exposto ao longo do trabalho, a modulação dos efeitos decorre de um processo ponderativo do julgador no qual deve ser dada preferência, na medida do possível, aos direitos fundamentais do cidadão. Dessa forma, o julgador deverá fazer um juízo de valor, de forma a avaliar qual medida será mais adequada, necessária e proporcional em sentido estrito a promover os princípios constitucionais e atingir de forma mais eficaz os fins do controle de constitucionalidade.

A retroatividade dos efeitos de decisão de inconstitucionalidade de norma tributária exonerativa por violação do princípio da isonomia não nos parece ser a medida mais adequada a promover os princípios constitucionais, visto que, nesse caso, o benefício concedido a determinado grupo incluído na norma exonerativa deixaria de existir, fazendo surgir a obrigação tributária e o grupo desfavorecido não teria qualquer benefício com tal decisão, uma vez que o Poder Judiciário não poderia incluí-lo na norma exonerativa, sob pena de atuar como legislador positivo, medida vedada em nosso ordenamento.

Sob essa perspectiva, podemos afirmar que a declaração de efeitos retroativos tornaria a medida ainda mais desproporcional, uma vez que afastaria o benefício de ambos os grupos ${ }^{151}$. Tal medida representaria ofensa ao princípio da segurança jurídica, que vem a proteger os contribuintes inicialmente englobados pela norma exonerativa, bem como ao princípio da irretroatividade tributária previsto no artigo 150, inciso III, da Constituição Federal, visto que implicaria cobrança do tributo ao grupo inicialmente beneficiado pela norma exonerativa.

${ }^{151}$ Ibid.,p.46. 
Assim, parece não haver dúvidas de que a modulação dos efeitos da decisão de inconstitucionalidade é a medida mais apropriada ao caso, uma vez que não deixa de dar aplicação ao princípio da segurança jurídica, ao proteger a confiança legítima do grupo englobado pela norma, bem como ao princípio da isonomia, protegendo os interesses do grupo injustamente excluído do benefício fiscal.

A mesma solução deve ser aplicada ao segundo caso de declaração de inconstitucionalidade de norma exonerativa mencionado, no qual a inconstitucionalidade decorre da inobservância de iter procedimental previsto ou da violação a princípios/normas constitucionais.

Nesse caso, o contribuinte, guiado pela confiança legítima de que pode utilizar-se do benefício fiscal, pauta seu comportamento em consonância com a norma exonerativa exarada. Caso a lei seja considerada inconstitucional e os efeitos dessa declaração de inconstitucionalidade sejam retroativos, surge a obrigação tributária aos contribuintes anteriormente protegidos pela norma exonerativa, violando-se, mais uma vez, o princípio previsto no artigo 150, inciso III, a, da Constituição Federal. Sobre o assunto, leciona Octávio Campos Fischer:

\begin{abstract}
Esta argumentação torna-se ainda mais clara quando da declaração de inconstitucionalidade de norma isentiva. $\mathrm{O}$ efeito para o futuro seria o mesmo da retirada da isenção por outra norma: aumento da tributação. (...) Portanto, em caso de decisão de inconstitucionalidade de norma mais benéfica ao contribuinte (de isenção ou não), há repristinação da norma anterior mais onerosa, mas esta somente poderá incidir a partir da referida decisão ou, no caso de um tributo regulado pela anterioridade, a partir do próximo exercício financeiro (ou, ainda, em se tratando de anterioridade especial, a partir dos noventa dias da decisão de inconstitucionalidade) ${ }^{152}$.
\end{abstract}

Em virtude do exposto, entendemos que em ambas as hipóteses de inconstitucionalidade de norma tributária exonerativa, a melhor interpretação parece ser a observância dos direitos fundamentais dos

\footnotetext{
${ }^{152}$ FISCHER, Octávio Campos. Op. Cit., p. 278-279.
} 
contribuintes $^{153}$, que será resguardada mediante a modulação dos efeitos da declaração de inconstitucionalidade da norma, sob pena de violação ao princípio da segurança jurídica, aqui manifestado pela confiança legítima dos contribuintes beneficiados pela norma exonerativa, e da anterioridade tributária, tendo em vista que a retroatividade dos efeitos da decisão implicaria criação de tributo não previsto anteriormente.

\subsection{A modulação de efeitos em casos de mudança de jurisprudência em matéria tributária}

Conforme já analisado, o Supremo Tribunal Federal já se manifestou no sentido de possibilidade da modulação de efeitos de suas decisões em casos de mudança de orientação jurisprudencial. Em âmbito tributário, a questão ganha contornos próprios, que apontam para a necessidade de modulação de efeitos das decisões, independentemente da atribuição de efeitos prospectivos ser benéfica ao Fisco ou ao contribuinte.

A mudança de jurisprudência encontra relação estreita com a questão da segurança jurídica. Isto porque toda e qualquer obrigação, no que se incluem as obrigações tributárias, somente pode ser exigida caso seja razoavelmente previsível dentro do ordenamento. Ou seja, para que a

\footnotetext{
${ }^{153}$ No mesmo sentido se posiciona Hugo de Brito Machado: "Imaginemos a decisão que declara inconstitucional uma lei que isenta de tributo a importação de determinada mercadoria. Se tal decisão produzir efeitos a partir da edição da lei, então todas as importações já ocorridas ensejam a consideração daquelas importações como crime de descaminho. Constitui abuso de autoridade, entre outras condutas, a de levar à prisão e nela deter quem quer que se proponha a prestar fiança, permitida em lei (Lei $\mathrm{n}^{\circ} 4.989 / 65$, art. $4^{\circ}$, alínea e). Admitamos que uma decisão declara inconstitucional um dispositivo de lei que proíbe a fiança em determinada situação. Tal decisão, se tem efeito retroativo, levará a considerar-se cometido o crime de abuso de autoridade pelo policial que prendeu, ou manteve preso, qualquer pessoa naquela situação em que a fiança era proibida, mas deixou de ser com a declaração de inconstitucionalidade. A decisão que declara inconstitucional uma lei que altera a destinação de verbas públicas, se produzir efeito retroativo levará a que se considere cometido o crime previsto no art. 315, do Código Penal, "dar às verbas ou rendas públicas aplicação diversa da estabelecida em lei”, por parte de todos quantos tenham obedecido a lei declarada inconstitucional. Inúmeros outros exemplos podem ser citados, a demonstrar que admitir o efeito retroativo da decisão que declara a inconstitucionalidade de uma lei pode levar a situações verdadeiramente absurdas" Apud. SILVA, Sérgio André R. G. da. Comentários acerca dos efeitos da decisão proferida no âmbito do controle abstrato da constitucionalidade das norma stributárias. Revista Dialética de Direito Tributário, São Paulo, n. 83, p. 150-167, ago.2002. p. 164-165.
} 
obrigação tributária seja imputada ao contribuinte, tanto este como o Fisco precisam ter certeza e segurança em relação ao direito no qual é pautada esta obrigação.

Tanto o contribuinte como o Fisco guiam suas relações na confiança que possuem na manutenção do entendimento consolidado pelo Supremo Tribunal Federal, estando protegidos, portanto, pelos princípios da confiança legítima e da boa-fé.

Dessa forma, quando a orientação jurisprudencial do Tribunal Constitucional é alterada, esta não pode ocorrer em desrespeito aos princípios da segurança jurídica e da confiança legítima, devendo ser feito um juízo de proporcionalidade entre os princípios acima mencionados e o princípio constitucional protegido pela decisão que alterou a jurisprudência.

Em âmbito tributário, a alteração de jurisprudência pode representar o ressurgimento de um tributo ou de uma exoneração tributária ou pode representar a nulidade de uma norma tributária impositiva ou exonerativa anteriormente entendida como constitucional.

Caso a decisão modificativa de jurisprudência determine a inconstitucionalidade de um tributo entendido anteriormente pelo Supremo Tribunal Federal como constitucional, deve ser levado em consideração que tanto o Fisco como os contribuintes guiaram suas relações com base no posicionamento anterior. Dessa forma, entendemos que a decisão modificativa de jurisprudência precisa ter seus efeitos modulados, devendo a inconstitucionalidade ser considerada somente a partir desta decisão, respeitado o direito à ação de repetição de indébito dos contribuintes que tenham se insurgido contra a cobrança em sede administrativa ou judicial. 
A esse respeito, é importante destacar que a hipótese de mudança de jurisprudência diverge da declaração de inconstitucionalidade de norma impositiva vista anteriormente, uma vez que, nesta última, não há qualquer entendimento que baseie a cobrança do tributo pelo Fisco, o que justifica a atribuição de efeitos retroativos totais. Na hipótese em referência, o tributo é criado sob um manto de legalidade, visto que o próprio tribunal, em um primeiro momento, declarou ser constitucional sua cobrança, mudando seu entendimento posteriormente.

Em casos de alteração de jurisprudência no sentido de reverter posição consolidada no Tribunal Constitucional de inconstitucionalidade pela constitucionalidade da norma tributária impositiva, a modulação dos efeitos da decisão também deve ser efetuada. Isto porque a atribuição de efeitos retroativos prejudicaria aos contribuintes, que vinham se comportanto de acordo com o entendimento jurisprudencial anterior ${ }^{154}$. Sobre o assunto, menciona Célio Armando Janczeski:

Não há dúvidas de que o contribuinte, frente à pacificação da jurisprudência (anterior ao novo posicionamento ditado pela decisão do Supremo), programouse para não pagar o tributo, planejando sua vida e seus negócios como se este encargo não fosse devido. Se, de um momento para o outro, aquilo que não era devido se transforma em devido com juros, atualização monetária e multa, exigível no período não prescrito, haverá manifesta violação na confiança do contribuinte que acreditou no Poder Judiciário como um todo ${ }^{155}$.

Além disso, não parece forçoso afirmar que a cobrança de tributo anteriormente considerado inconstitucional configuraria afronta ao

\footnotetext{
${ }^{154}$ Sobre o assunto é interessante mencionar observação de Luis Roberto Barroso: "Essa mesma conclusão decorre igualmente da legislação tributária. O art. 146 do CTN dispõe que eventual mudança de interpretação, fruto de decisão administrativa ou judicial, equivale à edição de lei nova e apenas poderá ser aplicada aos fatos ocorridos em momento posterior à introdução do novo entendimento, ou seja, da nova norma. Embora o dispositivo trate de forma específica do lançamento, seu fundamento legal pode ser generalizado de forma inteiramente consistente". BARROSO, Luis Roberto. Mudança da jurisprudência do Supremo Tribunal Federal em matéria tributária. Segurança Jurídica e modulação dos efeitos temporais das decisões judiciais. Revista de Direito do Estado. n. 2, p. 261-288, abr./jun.2006, p. 283.

${ }^{155}$ JANCZESKI, Célio Armando. A declaração de inconstitucionalidade com efeitos limitados, a supremacia constitucional e o direito tributário. Revista Dialética de Direito Tributário. São Paulo, n. 157 , p. $17-26$. out. 2008 , p. 24.
} 
princípio da irretroatividade tributária, visto que a alteração do entendimento jurisprudencial fez surgir subitamente tributo anteriormente entendido como inconstitucional.

Pode-se dizer que a alteração de jurisprudência produz os mesmos efeitos da edição de um novo ato legislativo. Assim, o entendimento anteriormente adotado pelo Supremo Tribunal Federal configuraria a norma em vigor, sendo alterado pelo novo posicionamento do Tribunal Constitucional que importará em norma nova e resultará na modulação de efeitos da decisão que alterou o entendimento jurisprudencial, em respeito ao princípio da segurança jurídica.

A esse respeito, afirma Luciana de Pontes Saraiva:

Se a mudança de jurisprudência produzir efeitos retroativos, atingindo legítimas expectativas dos jurisdicionados protegidas pelo princípio da segurança jurídica, a modulação de efeitos deverá ser aplicada. Não restará ao Tribunal Constitucional outra opção, sob pena de lesar o interesse público consubstanciado na previsibilidade dos precedentes e na confiança dos administrados na estabilidade das decisões judiciais. Não se pode olvidar que o Poder Judiciário possui dentre as suas mais relevantes funções a pacificação dos conflitos sociais, em caráter de definitividade. A mudança de entendimentos consolidados pela Corte Constitucional, sem que haja a devida transição proporcionada pela modulação temporal, produz exatamente o efeito inverso ao almejado pelo exercício da função jurisdicional: instabilidade, incerteza e insegurança ${ }^{156}$.

Dessa forma, a modulação de efeitos em caso de alteração de precedente em âmbito tributário seria a melhor medida a ser tomada, visto que levaria em consideração tanto o princípio protegido pela decisão modificativa de jurisprudência quanto os princípios constitucionais da segurança jurídica, confiança legítima, boa-fé e irretroatividade tributária.

\footnotetext{
${ }^{156}$ SARAIVA, Luciana de Pontes. Op. Cit., p. 121.
} 


\subsection{Análise da modulação dos efeitos de decisões proferidas pelo Supremo Tribunal Federal em matéria tributária}

Por todo o exposto até o momento, podemos resumir a questão da modulação de efeitos em matéria tributária da seguinte forma: (i) em caso de declaração de inconstitucionalidade de norma impositiva, os efeitos da decisão devem ser retroativos, de forma a proteger os direitos fundamentais dos contribuintes; (ii) em caso de declaração de inconstitucionalidade de norma exonerativa, prevalecem os princípios constitucionais que levam à proteção dos contribuintes, porém, nestes casos, deve ser atribuído efeito prospectivo à decisão e (iii) em caso de alteração da jurisprudência, os efeitos da decisão devem ser sempre prospectivos, visto que tanto o contribuinte como o fisco possuíam confiança legítima no entendimento anterior, devendo esta ser resguardada, sob pena de violação ao princípio da segurança jurídica.

Traçado este breve panorama e avaliados os princípios constitucionais que corroboram com as conclusões acima elencadas, analisaremos algumas decisões proferidas pelo Supremo Tribunal Federal em matéria tributária nas quais a atribuição de efeitos prospectivos à decisão foi suscitada, de forma a observar os parâmetros pelos quais a modulação de efeitos vem sendo admitida nesses casos.

A questão da atribuição de efeitos prospectivos à declaração de inconstitucionalidade proferida pelo STF veio à tona em inúmeros recursos extraordinários interpostos pelo Município do Rio de Janeiro a respeito da possibilidade de alíquota progressiva do Imposto sobre propriedade predial e territorial urbana (IPTU), reiteradamente considerada inconstitucional antes da entrada em vigor da Emenda Constitucional n. 29/2000, que conferiu constitucionalidade ao IPTU progressivo. 
Em suma, o Município do Rio de Janeiro pleiteava a modulação dos efeitos das decisões que declaravam a alíquota progressiva inconstitucional sob o argumento da segurança jurídica, uma vez que a lei foi aplicada por longo período sem ser questionada pelos contribuintes e do apelo fiscal, visto que a arrecadação do tributo já teria sido convertida em prol dos contribuintes $^{157}$.

O Ministro Gilmar Mendes, admitindo a modulação em tese, afastou a mesma no julgamento do Agravo de Instrumento n. $582.280^{158}$ :

$\mathrm{O}$ princípio da nulidade continua a ser regra também. O afastamento de sua incidência dependerá de severo juízo de ponderação que, tendo em vista análise fundada no princípio da proporcionalidade, faça prevalecer a idéia de segurança jurídica ou outro princípio constitucional relevante manifestado sob a forma de interesse social preponderante. Assim, aqui, a não aplicação do princípio da nulidade não se há de basear em consideração de política judiciária, mas em fundamento constitucional próprio. (...) Não há indicação objetiva de repercussão financeira eventualmente sofrida pela municipalidade. $\mathrm{O}$ acórdão do Tribunal de Justiça do Rio de Janeiro é de 18 de novembro de 2003. O recurso extraordinário foi protocolado em 18 de maio de 2004. O agravo foi protocolado pelo interessado por volta de $1^{\circ}$ de setembro do mesmo ano de 2004; é de se presumir que a distância temporal não qualifica o aspecto fático que justifique a modulação dos efeitos de não recepção, como pretendido pelo agravante.

Manifestando-se expressamente sobre o argumento fiscal alegado pela municipalidade, assim afirmou o Ministro Joaquim Barbosa no julgamento do Agravo Regimental no Agravo de Instrumento n. 681.484:

Evidentemente, a possibilidade que o sistema jurídico confere ao Supremo Tribunal Federal para modular os efeitos da declaração de inconstitucionalidade e a destinação do produto da arrecadação ao exercício de atividades estatais não podem redundar na imunização do Estado ao dever de zelar pela validade das normas jurídicas que cria, favorecendo assim a especulação lega ${ }^{159}$.

\footnotetext{
${ }^{157}$ HARADA, Ricardo Augusto Saavedra. Op. Cit., p. 73.

${ }^{158}$ STF, AI 582280 AgR, Relator: Min. Celso de Mello, Segunda Turma, julgado em 12.09.2006, DJ 06.11.2006.

${ }^{159}$ STF, AI 681484 AgR, Relator: Min. Joaquim Barbosa, Segunda Turma, julgado em 20.11.2007, DJ de 14.12.2007.
} 
Percebe-se, portanto, que no julgamento da inconstitucionalidade da alíquota progressiva de IPTU, o Supremo Tribunal Federal se declarou contrário à modulação de efeitos, afirmando não poder ser atribuído efeito prospectivo à decisão em virtude de argumentos de política fiscal, em perfeita consonância com o exposto ao longo deste trabalho.

No julgamento da inconstitucionalidade do direito de crédito do imposto sobre produtos industrializados (IPI) na aquisição de insumos sujeitos à alíquota zero, por sua vez, o Supremo Tribunal Federal, mesmo diante de uma situação na qual a mudança de entendimento jurisprudencial era evidente, optou por atribuir efeitos retroativos à decisão, em total desrespeito ao princípio da segurança jurídica.

A discussão teve início em 18.12.2002, quando o Plenário do Supremo Tribunal Federal determinou, por nove votos a um, que nas operações tributadas com base na alíquota zero, os contribuintes de IPI teriam direito de se creditar dos valores recolhidos a esse título nas operações anteriores ${ }^{160}$. Sobre o assunto afirmou o Ministro Relator Nelson Jobim:

Se o contribuinte do IPI pode creditar o valor dos insumos adquiridos sob o regime de isenção, inexiste razão para deixar de reconhecer-lhe o mesmo direito na aquisição de insumos favorecidos pela alíquota zero, pois nada extrema, na prática, as referidas figuras desonerativas, notadamente quando se trata de aplicar o princípio da não-cumulatividade. A isenção e a alíquota zero em um dos elos da cadeia produtiva desapareceriam quando da operação subsequente, se não admitido o crédito ${ }^{161}$.

\footnotetext{
${ }^{160}$ STF, RE 350446, Relator: Min. Nelson Jobim, Tribunal Pleno, julgado em 18.12.2002, DJ 06.06.2003.

${ }^{161}$ Apud. BARROSO, Luis Roberto. Mudança da jurisprudência do Supremo Tribunal Federal em matéria tributária. Segurança Jurídica e modulação dos efeitos temporais das decisões judiciais. Revista de Direito do Estado. n. 2, p. 261-288, abr./jun.2006, p. 2.
} 
A decisão em questão baseou-se em acórdão proferido pelo STF no julgamento do RE $212.484^{162}$, no qual foi determinado que o creditamento do valor do tributo incidente sobre insumos adquiridos sob o regime de isenção não ofendia o princípio da não cumulatividade previsto no art. 153, parágrafo terceiro, inciso II, da Constituição Federal. Dessa forma, sendo possível o creditamento em hipótese de isenção, não haveria óbice ao creditamento em casos de insumos favorecidos pela alíquota zero.

A partir do julgamento em comento, os recursos extraordinários interpostos pela União passaram a ser rejeitados monocraticamente pelos ministros do STF com base no art. 557 do Código de Processo Civil e o entendimento passou a ser adotado também no Superior Tribunal de Justiça, bem como nos Tribunais Regionais Federais ${ }^{163}$.

Ocorre que o STF, em julgamento do RE 353657/PR ${ }^{164}$, mudou seu posicionamento, passando a afastar o direito de crédito sobre insumos sujeitos à alíquota zero.

De acordo com o julgamento do recurso extraordinário mencionado, o IPI, tal como o ICMS, é não-cumulativo, conforme preceitua o artigo 153, parágrafo terceiro, inciso II, da Constituição Federal ${ }^{165}$. A admissão de creditamento em casos de não-tributação ou de alíquota zero implicaria

\footnotetext{
${ }^{162}$ STF, RE 212484, Relator: Min. Ilmar Galvão, Relator p/ Acórdão: Min. Nelson Jobim, Tribunal Pleno, julgado em 05.03.1998, DJ 27.11.1998.

${ }^{163}$ BARROSO, Luis Roberto. Mudança da jurisprudência do Supremo Tribunal Federal em matéria tributária. Segurança Jurídica e modulação dos efeitos temporais das decisões judiciais. Revista de Direito do Estado. n. 2, p. 261-288, abr./jun.2006, p. 263.

${ }^{164}$ STF, RE 353657, Relator: Min. Marco Aurélio, Tribunal Pleno, julgado em 25.06.2007, DJe041 DIVULG 06.03.2008 PUBLIC 07.03.2008.

${ }^{165}$ Art. 153. Compete à União instituir impostos sobre:

(...) IV - produtos industrializados

$\S 3^{\circ}$ - O imposto previsto no inciso IV: I - será seletivo, em função da essencialidade do produto; II - será não-cumulativo, compensando-se o que for devido em cada operação com o montante cobrado nas anteriores; III - não incidirá sobre produtos industrializados destinados ao exterior. IV - terá reduzido seu impacto sobre a aquisição de bens de capital pelo contribuinte do imposto, na forma da lei.

Disponível em http://www.planalto.gov.br/ccivil_03/constituicao/constitui\%C3\%A7ao.htm. Acesso em 30.05.2010.
} 
ofensa ao dispositivo mencionado, uma vez que a não-cumulatividade pressupõe, salvo previsão contrária na Constituição Federal, tributo devido e recolhido anteriormente e que, na hipótese de não-tributação ou de alíquota zero, não existe parâmetro normativo para definir a quantia a ser compensada.

Ante a mudança de entendimento jurisprudencial causada por esse julgamento, o Ministro Ricardo Lewandowski propôs a modulação dos efeitos da referida decisão, rejeitada, por maioria de votos, pelo Plenário do STF. Segundo o Ministro Relator Marco Aurélio:

contribuintes que ingressaram em juízo alcançarão, com o termo inicial de vigência retroativa aos cinco anos anteriores ao ajuizamento da ação. Conseguirão o implemento do crédito, embora à margem da autorização normativa constitucional, como se esta não estivesse em vigor desde 1998. Aqueles que não ingressaram em juízo, aconselhados corretamente pelo setor técnico, sofrerão as peias dos dois institutos consagrados em Direito: a prescrição e a decadência, enquanto os outros lograrão verdadeiro enriquecimento ilícito, porque contrário à Constituição Federal ${ }^{166}$.

No mesmo sentido, se manifestou o Ministro Eros Grau:

(...) nenhuma razão relacionada ao interesse social, menos ainda a "excepcional interesse social", prospera no sentido de aquinhoarem-se empresas que vieram a juízo afirmando interpretação que esta Corte entendeu equivocada. Fizeram-no, essas empresas, por sua conta e risco. É seguramente inusitado: o empresário pretende beneficiar-se por créditos aos quais não faz jus; o Judiciário afirma que efetivamente o empresário não é titular de direito a esses mesmos créditos, mas o autoriza a fazer uso deles até certa data...Um "negócio da China" para os contribuintes, ao qual corresponde inimaginável afronta ao interesse social ${ }^{167}$.

Não parece ser razoável a rejeição à proposta de modulação de efeitos apresentada pelo Ministro Ricardo Lewandowski. A alteração jurisprudencial acima resultou em afronta aos princípios da segurança jurídica e da boa-fé, uma vez que o STF vinha se posicionando desde o

\footnotetext{
${ }^{166}$ CIMINELLI, Selma. Contribuições Previdenciárias - prescrição e decadência - o entendimento do STF - uma questão de princípios. Revista de Direito Tributário. São Paulo, n. 159,p.115-122, dez.2008, p. 119.

${ }^{167}$ Ibid., p. 119.
} 
julgamento do RE 350446 no sentido de conferir direito ao creditamento de IPI na aquisição de insumos sujeitos à alíquota zero ${ }^{168}$.

Ainda que não tenha ocorrido alteração legislativa, o comportamento dos contribuintes era pautado em uma expectativa legítima conferida pelos julgados do Supremo Tribunal Federal, o que deveria ter sido considerado pelos Ministros. A esse respeito, é importante mencionar que a aplicação de efeitos prospectivos à decisão não acarretaria perda de arrecadação da União, uma vez que os contribuintes somente teriam protegidas as compensações realizadas em operações anteriores à referida decisão ${ }^{169}$.

Ademais, deve ser destacado que a alteração jurisprudencial viola o princípio da irretroatividade tributária. Sobre o assunto leciona Luis Roberto Barroso:

\begin{abstract}
A eventual mudança de jurisprudência por parte do STF na hipótese produz os mesmos efeitos da edição de um novo ato legislativo. Mesmo porque, como já se sublinhou, a norma não se confunde com o texto legislado, sendo na verdade o produto final da interpretação. Nesse passo, se a prática anterior dos contribuintes era expressamente reconhecida pelo STF e pelos demais tribunais como o comportamento exigível, este era o direito ou a norma em vigor. A nova orientação da Corte, caso venha a ser efetivamente formalizada, importará em norma nova e resultará na majoração do tributo a ser pago, podendo ser aplicada apenas a partir do momento de sua edição, e não retroativamente ${ }^{170}$.
\end{abstract}

\footnotetext{
${ }^{168}$ Sobre o assunto leciona Luis Roberto Barroso: “... se a cada momento o Judiciário pudesse modificar o seu entendimento sobre a legislação em vigor e atribuísse às novas decisões efeitos retroativos, instalar-se-ia a absoluta insegurança jurídica. Nada do que ocorreu no passado poderia ser jamais considerado definitivo pelos particulares, já que, a qualquer momento, a questão poderia ser revista por um novo entendimento do Judiciário. É evidente que uma construção nesse sentido seria totalmente incompatível com a ordem constitucional brasileira. (...) A aplicação do que se acaba de expor ao caso é bastante simples. Se, no julgamento do RE 353.657, o STF vier efetivamente a rever orientação que seguia, estará impondo aos jurisdicionados obrigação nova e diversa. E, do ponto de vista tributário, substancialmente mais gravosa do que aquela que antes se extraía da mesma legislação. (...) Em suma: eventual nova decisão da Corte, uma vez que importa modificação da ordem jurídica material, apenas poderá afetar os fatos futuros" BARROSO, Luis Roberto. Mudança da jurisprudência do Supremo Tribunal Federal em matéria tributária. Segurança Jurídica e modulação dos efeitos temporais das decisões judiciais. Revista de Direito do Estado. n. 2, p. 261-288, abr./jun.2006, p. 275.

${ }^{169}$ MELLO, Celso Antonio Bandeira de. Segurança Jurídica e Mudança de Jurisprudência. . Revista de Direito do Estado n.6:327-338, abr/jun de 2007.p, 228

${ }^{170}$ BARROSO, Luis Roberto. Mudança da jurisprudência do Supremo Tribunal Federal em matéria tributária. Segurança Jurídica e modulação dos efeitos temporais das decisões judiciais. Revista de Direito do Estado. n. 2, p. 261-288, abr./jun.2006, p. 283.
} 
A mesma situação ocorreu no julgamento da isenção da Contribuição para o Financiamento da Seguridade Social (Cofins) em relação às sociedades profissionais.

A Cofins possui previsão constitucional no artigo 195, inciso I, letra b, da Constituição Federal. Sua instituição coube à Lei Complementar n. 70/91 que, em seu artigo $6^{\circ}$, inciso II, determinou a isenção de Cofins para as sociedades civis dispostas no artigo $1^{\circ}$ do Decreto-lei n. 2.397/87 que, por sua vez, trata das "sociedades civis de prestação de serviços profissionais relativos ao exercício de profissão legalmente regulamentada, registradas no Registro Civil das Pessoas Jurídicas e constituídas exclusivamente por pessoas físicas domiciliadas no País" ${ }^{\prime 171}$.

Ocorre que a Lei n. 9.430/96, por meio de seu artigo 56, revogou a isenção concedida pela Lei Complementar n. 70/91, nos seguintes termos:

Art. 56. As sociedades civis de prestação de serviços de profissão legalmente regulamentada passam a contribuir para a seguridade social com base na receita bruta da prestação de serviços, observadas as normas da Lei Complementar $\mathrm{n}^{\circ} 70$, de 30 de dezembro de 1991.

Parágrafo único. Para efeito da incidência da contribuição de que trata este artigo, serão consideradas as receitas auferidas a partir do mês de abril de 1997.

O dispositivo presente na Lei n. 9.430/96 colidiu frontalmente com o disposto na Lei Complementar n. 70/91, o que deu início a um grande debate a respeito de qual dispositivo normativo iria dispor a respeito da isenção das sociedades profissionais.

O cerne da discussão consistia em determinar se o dispositivo presente na Lei n. 9.430/96 colidia com o princípio da hierarquia das leis ou não, visto que parte da doutrina pátria entendia que uma lei ordinária não

\footnotetext{
${ }^{171}$ SÁ, Rodrigo Cesar Caldas de. As Sociedades de Profissionais e a Isenção da Cofins: uma Releitura à Luz de Recentes Posicionamentos no STJ e no STJ. Revista Dialética de Direito Tributário. São Paulo, n. 128, p. 64-71, mai.2006, p. 64.
} 
poderia revogar isenção concedida por Lei Complementar, enquanto outra afirmava que não haveria tal hierarquia entre as leis, entendendo que a Lei Complementar n. 70/91 teria invadido competência de lei ordinária ao tratar da isenção da Cofins ${ }^{172}$.

Após diversos julgados a respeito do tema, o Superior Tribunal de Justiça (STJ) editou a súmula n. 276 que determinava que as sociedades civis de prestação de serviços profissionais seriam isentas da Cofins, independentemente do regime tributário adotado.

O Supremo Tribunal Federal, em primeiro momento, entendeu que se tratava de uma questão infraconstitucional e não alterou o posicionamento defendido pelos ministros do STJ. Posteriormente, passou a entender que haveria uma violação ao artigo 97 da Constituição, uma vez que os acórdãos proferidos pelo STJ haviam afastado a aplicação do artigo 56 da Lei n. 9.430 sem declarar sua inconstitucionalidade em incidente julgado por maioria do Tribunal ${ }^{173}$. Assim, em julgamento do RE $377.457^{174}$, o Supremo Tribunal Federal determinou ser válida a revogação da isenção por entender que tem força de lei ordinária a lei complementar $n$. 70/91, uma vez que esta trata de questão reservada pela Constituição à lei ordinária $^{175}$.

Em virtude da mudança de entendimento, foi discutida a questão da modulação de efeitos da decisão proferida pelo $\operatorname{STF}^{176}$. Os ministros Celso

\footnotetext{
${ }^{172}$ Ibid., p. 65 .

${ }^{173}$ GODOI, Marciano Seabra de. Op. Cit., p. 313.

${ }^{174}$ STF, RE 377457, Relator Min. Gilmar Mendes, Tribunal Pleno, julgado em 17.09.2008, DJe241 DIVULG 18.12.2008 PUBLIC 19.12.2008.

${ }^{175}$ A esse respeito, destacamos o julgamento da ADC n. 1-DF (STF, ADC 1, Relator Ministro Moreira Alves, j. 01.12.1993, DJ 16.06.1995, pp. 18.213), na qual o STF determinou que a Lei Complementar n. 70/91 era apenas formalmente complementar, podendo ser alterada por lei ordinária.

${ }^{176}$ Sobre o assunto, cabe mencionar que o Partido da Social Democracia Brasileira (PSDB) ajuizou, em 22.04.2008, a ação direta de inconstitucionalidade n. 4.071(STF, ADI 4071, Relator Min. Menezes Direito, Tribunal Pleno, julgado em 22.04.2009, DJe-195 DIVULG 15.10.2009 PUBLIC 16.10.2009) com a finalidade de debater, em âmbito concentrado, o tema objeto dos REs 377.457/PR e 381.964/MG (STF, RE 381964, Relator Min. Gilmar Mendes, julgado em 17.09.2008, DIVULG 12.03.2009 PUBLIC 13.03.2009). A ADI n. 4071 foi apreciada
} 
de Mello, Ricardo Lewandowski, Carlos Britto, Eros Grau e Menezes

Direito entenderam ser necessária a modulação de efeitos no caso em comento. No entanto, a maioria dos ministros entendeu não ser cabível a modulação, pois a questão era manifestamente constitucional, o STF já havia se posicionado a respeito da força de lei ordinária da Lei Complementar n. 70/91 no julgamento da ADC n. 1-DF ${ }^{177}$ e o STF não havia declarado a inconstitucionalidade de lei, requisito necessário à modulação nos termos do art. 27 da Lei n. 9.868/99 ${ }^{178}$.

Marciano de Seabra Godoi, ao comentar o posicionamento defendido pelo STF, afirma ter andado bem o STF ao não modular os efeitos de sua decisão, uma vez que entende não ser legítima a confiança do contribuinte $^{179}$ em uma súmula do STJ que confrontava com entendimento já anunciado pelo $\mathrm{STF}^{180}$. No entanto, o posicionamento adotado pelo Supremo Tribunal Federal também sofreu críticas de parte da doutrina. Rodrigo Cesar Caldas de Sá, adotando posição diametralmente oposta à defendida por Marciano de Seabra Godoi, entende que a súmula do Superior Tribunal de Justiça não poderia ser ignorada pelos membros do Supremo Tribunal Federal, sob o risco de afronta ao princípio da segurança jurídica $^{181}$.

Filiamo-nos ao posicionamento adotado por Rodrigo Cesar Caldas de Sá, uma vez que o afastamento da súmula do Superior Tribunal de

\footnotetext{
monocraticamente pelo Ministro Menezes Direito que indeferiu o pedido por entender que a questão já havia sido decidida pelo Plenário no julgamento dos Res 377.457/PR e 381.964/MG.

${ }_{177}^{17 D}$ AD 1, Relator: Min.Moreira Alves, Tribunal Pleno, julgado em 01.12.1993, DJ 16.06.1995.

${ }^{178}$ GODOI, Marciano Seabra de.Op. Cit., p. 313.

${ }^{179}$ No mesmo sentido, afirma Celso de Albuquerque Silva: "Vê-se, pelas decisões dos diversos Tribunais Regionais Federais, que a doutrina judicial firmada pelo STJ e consubstanciada no verbete $\mathrm{n}^{\circ} 276$ de sua Súmula de jurisprudência dominante, não logrou fazer fortuna nem se estabilizar e/ou se uniformizar, requisitos absolutamente necessários para gerar a justificável confiança dos contribuintes, a legitimar a modulação temporal dos efeitos de decisão posterior do STF que lhes fosse desfavorável" SILVA, Celso de Albuquerque. Cofins das Sociedades Civis de Profissão Regulamentada e o Princípio da Segurança Jurídica. Um caso de Modulação de Efeitos Temporais da Decisão a ser Proferida pelo Supremo Tribunal Federal? Revista Dialética de Direito Tributário, São Paulo, n. 155, p. 07-17, ago.2008, p. 14.

${ }^{180}$ GODOI, Marciano Seabra de. Op. Cit. p. 314

${ }^{181}$ SÁ, Rodrigo Cesar Caldas de. Op. Cit., p. 70.
} 
Justiça pelo Supremo Tribunal Federal não só afronta o princípio da segurança jurídica e o princípio da boa-fé, como acaba, ainda que de forma transversa, por criar tributo novo (uma vez que o posicionamento anterior era no sentido de isenção da Cofins). A criação de tributo novo surpreende o contribuinte que possuia uma legítima expectativa de se ver isento do pagamento em virtude de posicionamento sumulado pelo STJ e acaba por violar o princípio da irretroatividade tributária.

Por fim, cabe mencionar o julgamento da inconstitucionalidade dos artigos 45 e 46 da Lei n. 8.212/91, no qual foram modulados os efeitos da decisão de forma a impedir a repetição de indébito dos contribuintes que não haviam discutido o crédito em âmbito judicial ou administrativo até 11 de junho de 2008.

A respeito desta decisão, é importante destacar que a Constituição Federal determina em seu artigo 146, inciso III, letra b, que cabe à lei complementar dispor sobre normas gerais em matéria de legislação tributária a respeito de prescrição em decadêcia ${ }^{182}$. Tais regras estão dispostas nos artigos 173 e 174 do Código Tributário Nacional.

Ocorre que a Lei n. 8.212/91, em flagrante violação ao disposto no Código Tributário Nacional e tratando de matéria reservada apenas à lei complementar, dispôs, em seus artigos 45 e 46, sobre a decadência do direito da Fazenda Nacional de lançar contribuições previdenciárias, bem

\footnotetext{
${ }^{182}$ Art. 146. Cabe à lei complementar: I - dispor sobre conflitos de competência, em matéria tributária, entre a União, os Estados, o Distrito Federal e os Municípios; II - regular as limitações constitucionais ao poder de tributar; III - estabelecer normas gerais em matéria de legislação tributária, especialmente sobre: a) definição de tributos e de suas espécies, bem como, em relação aos impostos discriminados nesta Constituição, a dos respectivos fatos geradores, bases de cálculo e contribuintes; b) obrigação, lançamento, crédito, prescrição e decadência tributários; c) adequado tratamento tributário ao ato cooperativo praticado pelas sociedades cooperativas. d) definição de tratamento diferenciado e favorecido para as microempresas e para as empresas de pequeno porte, inclusive regimes especiais ou simplificados no caso do imposto previsto no art. 155, II, das contribuições previstas no art. 195, I e $\S \S 12$ e 13, e da contribuição a que se refere o art. 239. Disponível em http://www.planalto.gov.br/ccivil_03/constituicao/constitui\%C3\%A7ao.htm. Acesso em 30.05.2010.
} 
como sobre o prazo prescricional de execução dessas contribuições, nos seguintes termos:

Art. 45. O direito da Seguridade Social apurar e constituir seus créditos extinguese após 10 (dez) anos contados:

I - do primeiro dia do exercício seguinte àquele em que o crédito poderia ter sido constituído;

II - da data em que se tornar definitiva a decisão que houver anulado, por vício formal, a constituição de crédito anteriormente efetuada.

Art. 46. O direito de cobrar os créditos da Seguridade Social, constituídos na forma do artigo anterior, prescreve em 10 (dez) anos.

A invalidade das disposições previstas vinha sendo reconhecida em todas as instâncias, inclusive no Superior Tribunal de Justiça ${ }^{183}$ e em alguns julgados do Supremo Tribunal Federal. Em 12.06.2008, no julgamento dos REs 556.664, 559.882, 559.943 e $560.626^{184}$, o Plenário do STF declarou a inconstitucionalidade da ampliação dos prazos de decadência e prescrição previstos nos artigos 45 e 46 da Lei n. 8.212/91 e da suspensão da prescrição tributária prevista no parágrafo único do artigo $5^{\circ}$ do Decreto-Lei $\mathrm{n}^{\mathrm{o}} 1.569 / 1977^{185}$, fato que ensejou, inclusive, a criação da súmula vinculante n. 8 do Supremo Tribunal Federal ${ }^{186}$, a saber:

Súmula vinculante $n^{\circ} 8$ : “São inconstitucionais o parágrafo único do artigo $5^{\circ}$ do Decreto-Lei $n^{\circ} 1.569 / 1977$ e os artigos 45 e 46 da Lei $n^{\circ} 8.212 / 1991$, que tratam de prescrição e decadência de crédito tributário.

\footnotetext{
${ }^{183}$ AI no REsp 616348/MG, Rel. Ministro Teori Albino Zavascki, Corte Especial, julgado em 15.08.2007, DJ 15.10.2007 p. 210.

${ }^{184}$ RE 556664, Relator: Min. Gilmar Mendes, Tribunal Pleno, julgado em 12.06.2008; RE 559882, Relator(a): Min Gilmar Mendes, Tribunal Pleno, julgado em 12.06.2008; RE 559943, Relator(a): Min. Carmem Lucia, Tribunal Pleno, julgado em 12.06.2008 e RE 560626, Relator(a): Min. Gilmar Mendes, Tribunal Pleno, julgado em 12.06.2008.

185،A despeito de o RE 556.664 não ter enfocado propriamente a inconstitucionalidade de leis impositivas (que criam ou modificam tributos), é indubitável que os argumentos utilizados nesse precedente poderiam se aplicar para justificar a "validação" de tributos incompatíveis com os preceitos constitucionais. Há uma similitude estreita entre a criação de tributos inconstitucionais e a cobrança de créditos impositivos com base em prazos decadenciais ou prescricionais acometidos por idêntico vício, visto que as regras de decadência e prescrição também dizem respeito ao direito tributário material e afetam os direitos e obrigações dos sujeitos da relação obrigacional, ao implicarem a extinção do crédito tributário (art. 156, v, do CTN). Por tal razão, a decisão comentada surtiu o mesmo efeito que teria uma a chancelar lei impositiva contrária à Constituição" VELLOSO, Andrei Pitten. A Temerária "modulação" dos efeitos da pronúncia dos efeitos da pronúncia de inconstitucionalidade em matéria tributária. Revista Dialética de Direito Tributário, São Paulo, n. 157,p. 07-16, out.2008, p. 12.

${ }^{186}$ MACHADO, Raquel Cavalcanti Ramos. O consequencialismo jurídico e as modulações das decisões do STF. In: Grandes Questões atuais do direito tributário, $13^{\circ}$ volume. Coordenador Valdir de Oliveira Rocha. São Paulo: Dialética, 2009, p. 340-341.
} 
O Plenário do Supremo Tribunal Federal decidiu, ainda, modular os efeitos da decisão de inconstitucionalidade proferida, de forma que os contribuintes que já haviam quitado seus débitos sem estarem questionando o pagamento no momento da prolação da decisão não pudessem repetir o indébito $^{187}$.

Interessante observar que, no caso em comento, não obstante o Supremo Tribunal Federal somente ter solidificado posicionamento que já vinha sendo adotado pelos Tribunais, foi determinada a modulação dos efeitos da decisão, enquanto que no caso da isenção de Cofins das sociedades profissionais, os efeitos da decisão foram retroativos, mesmo havendo súmula do Superior Tribunal de Justiça em sentido contrário ${ }^{188}$.

De acordo com a decisão analisada, os créditos tributários pagos antes de 11 de junho de 2008 somente serão restituídos ou compensados caso o contribuinte tenha discutido judicial ou administrativamente o pagamento efetuado. Entendemos que tal posicionamento não está de acordo com os princípios constitucionais da isonomia e da segurança jurídica $^{189}$.

O STF, ao proceder a modulação de efeitos da decisão, limitou-se a mencionar alguns precedentes nos quais a modulação de efeitos havia sido acolhida, justificando, em seguida, a motivação pela qual entendeu não ser possível a atribuição de efeitos temporais tal como requerida pela Fazenda, uma vez que aqueles que já haviam ingressado com ações ou discutiam o crédito em âmbito administrativo deveriam ter seu direito à repetição de indébito. Ocorre que, em momento algum, o STF detalha os motivos pelos

\footnotetext{
${ }^{187}$ VELLOSO, Andrei Pitten. Op. Cit., p. 7.

${ }^{188}$ MACHADO, Raquel Cavalcanti Ramos. Op. Cit., p. 341.

${ }^{189}$ CIMINELLI, Selma. Op. Cit., p. 115.
} 
quais entendeu não ser cabível a repetição de indébito nos casos em que o contribuinte havia pago a contribuição inconstitucionalmente lançada ${ }^{190}$.

O ministro relator limitou-se a afirmar que "a declaração de inconstitucionalidade dos arts. 45 e 46 da Lei $n^{\circ}$ 8.212/1991 pode acarretar grande insegurança jurídica quanto aos valores pagos fora dos prazos quinquenais previstos no CTN e que não foram contestados administrativa ou judicialmente" ${ }^{191}$.

A afirmação de que a proteção ao direito de repetição de indébito dos contribuintes que efetuaram o pagamento das contribuições pode acarretar insegurança jurídica sofreu críticas por parte da doutrina. Sobre o assunto, afirma Andrei Pitten Velloso:

Se os preceitos são inconstitucionais e os contribuintes já versaram aos cofres públicos os valores exigidos pelo Fisco, a declaração da sua ilegitimidade jurídica deveria produzir o efeito de autorizá-los a postular a restituição do que pagaram ao arrepio da Constituição. Tal autorização, que sempre fez parte da nossa tradição jurídica, não implicaria insegurança jurídica alguma, haja vista o intérprete maior da Carta da República já ter se manifestado definitivamente sobre o direito aplicável à espécie e ninguém cogita reavivar os direitos à repetição de indébito fulminados pela prescrição, nos termos do art. 168 do Código Tributário Nacional. Ou seja, não abalaria a certeza jurídica quanto ao vício dos preceitos que ampliaram os prazos decadencial e prescricional estabelecidos pelo CTN e tampouco afetaria a segurança jurídica do Poder Público de não ter que satisfazer pretensões já prescritas. É óbvio que o reconhecimento pleno do direito à repetição de indébito não geraria insegurança jurídica; pelo contrário, reforçaria a segurança jurídica dos contribuintes quanto à efetividade dos seus direitos garantidos constitucionalmente, vindo a corroborar a força jurídica das limitações ao poder de tributar, frequentemente abalada por ações irresponsáveis do legislador ${ }^{192}$.

Outra crítica que se faz à modulação dos efeitos da decisão proferida pelo STF no caso em comento é que esta nega o direito à repetição de indébito dos contribuintes que efetuaram o pagamento e protege aqueles que se esquivaram da obrigação, em clara violação ao princípio da

\footnotetext{
${ }^{190}$ MACHADO, Raquel Cavalcanti Ramos. Op. Cit., p. 343.

${ }^{191}$ VELLOSO, Andrei Pitten. Op. Cit., p. 8.

${ }^{192}$ Ibid., p.8.
} 
isonomia. Novamente, transcrevemos posicionamento de Andrei Pitten Velloso:

Excluir do manto da Constituição os cidadãos cumpridores das obrigações instituídas pela legislação tributária enquanto se tutelam os maus pagadores e os sonegadores representa a derrocada dos pilares do Estado Democrático de Direito, o extermínio da ética estatal, a negação do que há de mais essencial às noções de igualdade e justiça ${ }^{193}$.

Ao que tudo indica, a atribuição de efeitos prospectivos à decisão teve como fundamento razões de política fazendária, visto que o direito à repetição de indébito dos contribuintes que efetuaram o pagamento poderia repercutir de forma negativa no erário. Razões de política fazendária não podem ser alegadas a fim de negar ao contribuinte direito a que faz jus por expressa previsão legal ${ }^{194}$. Portanto, ao impedir a repetição de indébito a esses contribuintes, o STF vem a beneficiar a Fazenda Nacional, entidade responsável pela edição da norma inconstitucional, em completa violação ao princípio geral de direito que veda o benefício proveniente da própria torpeza ${ }^{195}$.

Como se vê, poucos são os julgados que chegaram à análise do STF para decidir-se sobre a modulação de efeitos temporais das decisões de inconstitucionalidade proferidas em matéria tributária.

No entanto, através de uma análise dos julgados mencionados, podemos tecer algumas observações a respeito dos parâmetros que vêm sendo utilizados em matéria de modulação de efeitos suscitadas no âmbito tributário.

\footnotetext{
${ }^{193}$ Ibid., p. 15.

${ }^{194}$ Ibid., p.8.

${ }^{195}$ MACHADO, Raquel Cavalcanti Ramos. Op. Cit., p. 341.
} 
Primeiramente, é de se observar que as decisões são precariamente fundamentadas, não demonstrando de forma efetiva os princípios e valores constitucionais que foram tomados como base para a atribuição ou não de efeitos prospectivos às decisões proferidas.

A esse respeito, já destacamos que para que a modulação de efeitos seja atribuída ou afastada em um caso, o julgador deve fazer um juízo de valor de forma a ponderar os princípios constitucionais contrastantes e avaliar qual deles será o mais adequado, necessário e proporcional em sentido estrito a atingir de forma mais eficaz os fins do controle de constitucionalidade, devendo explicitar de forma detalhada os motivos que o levaram a adotar determinado posicionamento em detrimento de outro.

No entanto, não é o que vem ocorrendo. O STF, ao julgar a pertinência ou não da atribuição de efeitos prospectivos nos casos mencionados, não detalha as razões pelas quais entende ser aplicável ou não a modulação, fazendo uso de argumentações por vezes superficiais, sem adentrar de forma aprofundada no assunto.

Tal medida, além de ocasionar insegurança aos jurisdicionados, que não têm como observar os critérios e parâmetros adotados pelos Ministros do STF, também conduz à incoerência das decisões proferidas pelo Supremo Tribunal Federal.

Sobre o assunto, podemos destacar o julgado refererente ao IPTU, no qual a modulação de efeitos por motivos fiscais foi afastada e o caso de decadência e prescrição das contribuições previdenciárias, no qual houve impedimento à repetição de indébito para os contribuintes que não haviam discutido o crédito em sede administrativa/judicial, pautado em argumentos exclusivamente fiscais. 
Outra inconsistência flagrante pode ser observada nos julgamentos da inconstitucionalidade dos artigos 45 e 46 da Lei n. 8.212/91 e nos casos de isenção da Cofins e crédito de IPI na aquisição de insumos sujeitos à alíquota zero. No primeiro, a modulação de efeitos foi admitida mesmo havendo manifestação de todos os tribunais em defesa da inconstitucionalidade dos dispositivos. No caso de isenção da Cofins e do crédito de IPI, por sua vez, a atribuição de efeitos prospectivos foi afastada, em total desrespeito ao princípio da segurança jurídica que deveria ter sido observado em virtude da mudança de orientação jurisprudencial.

Como constatado, pode-se chegar à conclusão de que as manifestações dos Ministros a respeito do assunto não se encontram bem delineadas, sendo, por vezes, contraditórias, não logrando demonstrar de forma efetiva o exercício de ponderação realizado de forma a ensejar o afastamento de um determinado princípio em favor de outro.

As decisões do STF a respeito da modulação de efeitos oscilam, ora beneficiando os contribuintes, ora beneficiando o Fisco, o que ocorre tanto em casos de declaração de inconstitucionalidade como em casos de mudança de orientação jurisprudencial.

Percebe-se, portanto, que os Ministros do STF não só falham em determinar de forma clara os parâmetros utilizados para fundamentar seus votos no tocante à modulação de efeitos, como, na maioria dos casos, divergem diametralmente do entendimento que vem sendo defendido no presente trabalho, qual seja: a observância dos princípios fundamentais dos contribuintes nos casos de declaração de inconstitucionalidade de normas impositivas/exonerativas, com a ressalva para os casos de mudança de jurisprudência, nos quais a atribuição de efeitos prospectivos deve ser sempre adotada, seja em benefício dos contribuintes ou do Fisco, tendo em vista o princípio da proteção da confiança legítima. 


\section{CONCLUSÃO}

Como visto, a questão da modulação de efeitos em sede de controle de constitucionalidade é objeto de rica discussão doutrinária, sendo majoritária a corrente que a aceita, tanto em sede de controle concentrado, como em controle difuso, bem como nas hipóteses de mudança de orientação jurisprudencial, desde que seja feito um juízo de proporcionalidade no qual a modulação de efeitos seja considerada a medida mais adequada à efetivação dos princípios constitucionais envolvidos no caso concreto.

Em âmbito tributário, a discussão desse juízo de proporcionalidade envolve direitos fundamentais dos contribuintes, que são contrapostos a direitos fazendários, geralmente de cunho orçamentário. Conforme demonstrado, nestes casos, deve ser atribuido efeito retroativo à declaração de inconstitucionalidade, tendo em vista que as chamadas "razões de Estado" não são suficientes a embasar a produção de efeitos prospectivos de uma decisão. A esse respeito, destacamos a possibilidade de parcelamento do tributo declarado inconstitucional a ser restituído aos contribuintes como um dos principais argumentos contra a possibilidade de modulação de efeitos baseada em argumentos fiscais.

Existem, no entanto, determinados casos em que a modulação de efeitos apresenta-se como medida adequada, necessária e proporcional a solucionar situações nas quais princípios constitucionais são contrapostos. São os casos de declaração de inconstitucionalidade de norma tributária exonerativa e mudança de entendimento jurisprudencial.

No caso de inconstitucionalidade de norma exonerativa, esta pode ocorrer por violação ao princípio da isonomia ou por violação de norma/princípio constitucional ou violação de iter procedimental. $\mathrm{Na}$ 
primeira situação, a modulação dos efeitos se justifica em virtude de ser a medida mais razoável a ser aplicada ao caso, visto que a exclusão do grupo favorecido pela norma tornaria a situação ainda mais injusta e não há possibilidade de beneficiar o grupo preterido pela exoneração. Dessa forma, a retroatividade da declaração de inconstitucionalidade quebraria a confiança legítima do grupo beneficiado pela norma, bem como violaria o princípio da irretroatividade tributária, ocorrendo o mesmo na segunda hipótese de inconstitucionalidade de norma exonerativa.

$\mathrm{Na}$ hipótese de alteração de entendimento jurisprudencial fica ainda mais em evidência a confiança legítima dos jurisdicionados, uma vez que esta se baseia em entendimento do próprio Tribunal Constitucional que foi, em um momento posterior, alterado. Em matéria tributária, deve-se destacar que esta confiança legitima no entendimento jurisprudencial se opera tanto para o contribuinte como para o fisco, razão pela qual a modulação dos efeitos se faz ainda mais necessária, visto que ambas as partes da relação jurídico-tributária se guiaram com base no entendimento jurisprudencial que veio a ser alterado, devendo, portanto, ter essa confiança protegida, com base no princípio da segurança jurídica. É importante destacar, no entanto, que caso a decisão modificativa de jurisprudência entenda pela inconstitucionalidade de um tributo entendido anteriormente pelo Supremo Tribunal Federal como constitucional, deve ser respeitado o direito à restituição de indébito dos contribuintes que se insurgiram contra a norma no âmbito administrativo ou judicial.

Nesse sentido, causa surpresa observar que nas decisões proferidas pelo Supremo Tribunal Federal em âmbito tributário nas quais a modulação de efeitos vem sendo suscitada, as soluções admitidas têm sido muito diferentes do que aquelas que vêm sendo defendidas no presente estudo. 
Através de uma análise dos julgados mencionados a respeito de matéria tributária ao longo do presente trabalho, concluímos que as decisões muitas vezes são contraditórias, ora defendendo o argumento fiscal como base para a modulação, ora o afastando em benefício do contribuinte. São, por vezes, incoerentes, ao ponto de defender a modulação em casos de flagrante inconstitucionalidade de norma reiteradamente declarada inconstitucional por todos os tribunais e afastá-la em casos no qual a mudança de orientação jurisprudencial é flagrante.

Tal constatação é preocupante. Como já observado, a modulação de efeitos deve ser feita de forma a ponderar princípios constitucionais constrastantes e avaliar qual deles será o mais adequado, necessário e proporcional em sentido estrito a atingir de forma mais eficaz os fins do controle de constitucionalidade.

Conforme analisado, as decisões do STF falham em determinar de forma clara os parâmetros utilizados para fundamentar a atribuição ou afastamento de efeitos prospectivos, o que causa insegurança ao jurisdicionados que não podem contar com um posicionamento efetivo do Tribunal Constitucional a respeito do tema.

Ainda que a modulação dependa de um processo ponderativo a ser avaliado caso a caso, isto não significa que as decisões do Supremo Tribunal Federal não devam guardar coerência umas com as outras. Desse modo, não há como concordar com as conclusões do Supremo Tribunal Federal a respeito de modulação de efeitos de suas decisões em matéria tributária nos casos estudados.

Em virtude do exposto, encerramos o presente estudo reiterando nossa conclusão de que em sede de modulação de efeitos das decisões proferidas pelo STF em matéria tributária, o entendimento que parece 
melhor promover os princípios constitucionais, bem como atingir os fins do controle de constitucionalidade seria o afastamento da modulação em caso de declaração de inconstitucionalidade de norma impositiva, visando à proteção dos direitos fundamentais dos contribuintes e sua admissão em casos de declaração de inconstitucionalidade de norma exonerativa e nos casos de mudança de orientação jurisprudencial, de forma a proteger o princípio da segurança jurídica e irretroatividade tributária no primeito caso e a confiança legítima dos contribuintes e do Fisco no segundo. 


\section{REFERÊNCIAS}

\section{REFERÊNCIAS BIBLIOGRÁFICAS}

APPIO, Eduardo. Controle difuso de constitucionalidade: modulação dos efeitos, uniformização de jurisprudência e coisa julgada. $1^{\text {a }}$ reimpr. Curitiba: Juruá, 2010.

ÁVILA, Ana Paula. A modulação de efeitos temporais pelo STF no controle de constitucionalidade: ponderação e regras de argumentação para a interpretação conforme a Constituição do artigo 27 da Lei $n^{\circ}$ 9.868/99. Porto Alegre: Livraria do Advogado Editora, 2009. 182 p.

BARCELlOS, Ana Paula. Ponderação, Racionalidade e Atividade Jurisdicional. Rio de Janeiro: Renovar, 2005.

BARROSO, Luis Roberto. $O$ controle de constitucionalidade no Direito Brasileiro. $4^{a}$ ed.. São Paulo: Saraiva, 2009.

,Temas de Direito Constitucional. Rio de Janeiro:Renovar, 2001. Mudança da jurisprudência do Supremo Tribunal Federal em matéria tributária. Segurança Jurídica e modulação dos efeitos temporais das decisões judiciais. Revista de Direito do Estado. n. 2, p 261-288, abr./jun. 2006.

- Modulação dos efeitos temporais de decisão que altera jurisprudência consolidada. Quorum de deliberação. Disponível em http://www.oab.org.br/arquivos/pdf/Geral/Cofins.pdf. Acesso em 24.05.2010.

BONAVIDES, Paulo. Curso de Direito Constitucional. 18 a ed.. São Paulo: Malheiros, 2006.

CAPPELLETTI, Mauro. O controle judicial de constitucionalidade das leis no direito comparado. $2^{\mathrm{a}}$ ed. Porto Alegre: Fabris,1984. 
CEZAROTI, Guilherme. O consequencialismo jurídico e as modulações das decisões do STF. In: Rocha, Valdir de Oliveira (Coord.). Grandes Questões Atuais do Direito Tributário. $13^{\circ}$ volume. São Paulo: Dialética, 2009. p.135-152.

CIMINELLI, Selma. Contribuições Previdenciárias - prescrição e decadência - o entendimento do STF - uma questão de princípios. Revista de Direito Tributário. São Paulo, n. 159, p.115-122, dez.2008.

COÊLHO, Sacha Calmon Navarro. Teoria Geral do Tributo, da Interpretação e da Exoneração Tributária. 3 ed.. São Paulo: Dialética, 2003.

FERREIRA, Carlos Wagner Dias. Modulação dos efeitos da declaração de inconstitucionalidade no controle difuso. Disponível em http://www.jfpe.gov.br/biblioteca/juizes/carlos_wagner_esmafe12_p155178.pdf. Acesso em 10.05.2010.

FERREIRA FILHO, Manoel Gonçalves. O sistema constitucional brasileiro e as recentes inovações no controle de constitucionalidade. Revista de Direito Administrativo. n. 220, p. 1-17, abr./jun. 2000.

FISCHER, Octávio Campos. Os efeitos da declaração de inconstitucionalidade no direito tributário brasileiro. Rio de Janeiro: Renovar, 2004.

GARCÍA DE ENTERRÍA, Eduardo. Justicia Constitucional: la doctrina prospectiva em la declaración de ineficacia de las leyes inconstitucionales. Revista de Direito Público. São Paulo, v. 22, n. 92, p. 5 - 16, out./dez. 1989. GODOI, Marciano Seabra de. O consequencialismo jurídico e as modulações dos efeitos das decisões do STF. In ROCHA, Valdir de Oliveira (Org.). Grandes Questões Atuais do Direito Tributário. 13 volume. São Paulo: Dialética, 2009. p. 286-320.

HAMILTON, Alexander, MADISON, James e JAY, John. O Federalista, artigo 78. Belo Horizonte: Ed. Líder, 2003. 
HURTADO, Ricardo Augusto Saavedra. A modulação dos efeitos temporais das decisões do Supremo Tribunal Federal em controle de constitucionalidade em matéria tributária. Rio de Janeiro. 2008. 82p. Monografia (Especialização em Advocacia Pública) - Escola Superior de Advocacia Pública do Estado (ESAP) / Faculdade de Direito da Universidade do Estado do Rio de Janeiro.

JANCZESKI, Célio Armando. A declaração de inconstitucionalidade com efeitos limitados, a supremacia constitucional e o direito tributário. Revista Dialética de Direito Tributário. São Paulo, n. 157, p. 17-26. out. 2008

LEAL, Saul Tourinho. Modular para não pagar: a adoção da doutrina prospectiva negando direito aos contribuintes. Revista Dialética de Direito Tributário. São Paulo, n. 158, p 78 - 86, nov. 2008.

MACHADO, Raquel Cavalcanti Ramos. O consequencialismo jurídico e as modulações das decisões do STF. In ROCHA, Valdir de Oliveira (Org.). Grandes Questões Atuais do Direito Tributário. $13^{\circ}$ volume. São Paulo: Dialética, 2009. p. 334-343.

MACIEIRA, Luciana de Assunção. A inconstitucionalidade do art. 27 da Lei 9.868/99 quanto ao regulamento processual dos efeitos do provimento final em sede de controle abstrato. Revista da ESMAPE, v. 6, n. 13, p. 291309, jan./jun. 2001.

MARTINS, Ives Gandra da Silva e MENDES, Gilmar Ferreira. Controle Concentrado de Constitucionalidade: comentários à Lei n. 9.868, de 10-111999. $3^{a}$ ed. São Paulo: Saraiva, 2009. 637 p.

MEIRELLES, HELY LOPES. Direito Administrativo Brasileiro. $25^{\mathrm{a}}$ ed. São Paulo: Malheiros, 2000.

MELLO, Celso Antonio Bandeira de. Segurança Jurídica e Mudança de Jurisprudência. Revista de Direito do Estado, n.6, p. 327-338, abr./jun. 2007. 
MENDES, Gilmar Ferreira. Direitos Fundamentais e Controle de Constitucionalidade: estudos de direito constitucional. $3^{\mathrm{a}}$ ed.. São Paulo: Saraiva, 2004.

MORAES, Alexandre de. Direito Constitucional. 19ª ed.. São Paulo: Atlas, 2006.

PIMENTA, Paulo Roberto Lyrio. Efeitos da decisão de inconstitucionalidade em direito tributário. São Paulo: Dialética, 2002.

SÁ, Rodrigo Cesar Caldas de. As Sociedades de Profissionais e a Isenção da Cofins: uma Releitura à Luz de Recentes Posicionamentos no STJ e no STJ. Revista Dialética de Direito Tributário. São Paulo, n. 128, p 64 - 71, mai.2006.

SARAIVA, Luciana de Pontes. A modulação de efeitos como técnica de decisão na jurisdição constitucional. Rio de Janeiro. 2009. 153p. Dissertação (Mestrado em Direito Público) - Faculdade de Direito da Universidade do Estado do Rio de Janeiro.

SARLET, Info Wolfgang. Arguição de Descumprimento de Preceito Fundamental: Alguns aspectos controversos. In: Arguição de Descumprimento de Preceito Fundamental: Análises à Luz da Lei n. 9.882/1999. São Paulo; Atlas, 2001.

SILVA, Celso de Albuquerque. Cofins das Sociedades Civis de Profissão Regulamentada e o Princípio da Segurança Jurídica. Um caso de Modulação de Efeitos Temporais da Decisão a ser Proferida pelo Supremo Tribunal Federal? Revista Dialética de Direito Tributário. São Paulo, n. 155, p 07 - 17, ago. 2008.

SILVA, Sérgio André R.G. da. Comentários acerca dos Efeitos da Decisão Proferida no Âmbito do Controle Abstrato da Constitucionalidade das Normas Tributárias. Revista Dialética de Direito Tributário. São Paulo, n. 83, p 150 - 167, ago. 2002. 
SILVA, José Afonso da, Curso de Direito Constitucional Positivo. $27^{\mathrm{a}}$ ed. São Paulo: Malheiros, 2006. 924 p.

SILVA, Renata Elaine. Modulação dos efeitos da decisão em matéria tributária: possibilidade ou não de "restringir os efeitos daquela declaração". Revista Dialética de Direito Tributário. São Paulo, n. 170, p 52 - 63, nov. 2009.

SORMANI, Alexandre. Inovações da ação direta de inconstitucionalidade e da ação declaratória de constitucionalidade: uma visão crítica da Lei n. 9.868/99 sob o viés do princípio da segurança jurídica. São Paulo: Juarez de Oliveira, 2004. 208 p.

TAVARES, Alexandre Macedo. A responsabilidade estatal pelo desempenho irregular da função de legislar como engrenagem do sistema de freios e contrapesos à possibilidade de o STF atribuir eficácia prospectiva às decisões de inconstitucionalidade em matéria tributária. Revista Dialética de Direito Tributário. São Paulo, n. 159, p 07 - 18, dez. 2008.

VELLOSO, Andrei Pitten. A temerária "modulação" dos efeitos da pronúncia de inconstitucionalidade em matéria tributária. Revista Dialética de Direito Tributário. São Paulo, n. 157, p 07 - 16, out. 2008.

\section{REFERÊNCIAS JURISPRUDENCIAIS}

BRASIL. Superior Tribunal de Justiça. AI no REsp 616348/MG (Corte Especial) CONSTITUCIONAL, PROCESSUAL CIVIL E TRIBUTÁRIO. INCIDENTE DE INCONSTITUCIONALIDADE. DO ARTIGO 45 DA LEI 8.212, DE 1991. OFENSA AO ART. 146, III, B, DA CONSTITUIÇÃO. 1. As contribuições sociais, inclusive as destinadas a financiar a seguridade social (CF, art. 195), têm, no regime da Constituição de 1988, natureza tributária. Por isso mesmo, aplica-se também a elas o disposto no art. 146, III, b, da Constituição, segundo o qual cabe à lei complementar dispor sobre normas gerais em matéria de prescrição e decadência tributárias, compreendida nessa cláusula inclusive a fixação dos respectivos prazos. Conseqüentemente, padece de inconstitucionalidade 
formal o artigo 45 da Lei 8.212, de 1991, que fixou em dez anos o prazo de decadência para o lançamento das contribuições sociais devidas à Previdência Social. 2. Argüição de inconstitucionalidade julgada procedente. Rel. Ministro Teori Albino Zavascki, julgado em 15.08.2007, DJ 15.10.2007 p. 210. Disponível em http://www.stj.jus.br. Acesso em 30.05.2010.

Supremo Tribunal Federal. ADC 1 (Tribunal Pleno) Ação

Declaratória de Constitucionalidade. Artigos $1^{\circ}, 2^{\circ}, 9^{\circ}$ (em parte), 10 e 13 (em parte) da Lei Complementar $\mathrm{n}^{\circ}$ 70, de 30.12.91. COFINS. - A delimitação do objeto da ação declaratória de constitucionalidade não se adstringe aos limites do objeto fixado pelo autor, mas estes estão sujeitos aos lindes da controvérsia judicial que o autor tem que demonstrar. Improcedência das alegações de inconstitucionalidade da contribuição social instituída pela Lei Complementar no 70/91 (COFINS). Ação que se conhece em parte, e nela se julga procedente, para declarar-se, com os efeitos previstos no parágrafo $2^{\circ}$ do artigo 102 da Constituição Federal, na redação da Emenda Constitucional n ${ }^{\circ} 3$, de 1993, a constitucionalidade dos artigos $1^{\circ}, 2^{\circ}$ e 10 , bem como das expressões "A contribuição social sobre o faturamento de que trata esta lei não extingue as atuais fontes de custeio da Seguridade Social "contidas no artigo $9^{\circ}$, e das expressões "Esta lei complementar entra em vigor na data de sua publicação, produzindo efeitos a partir do primeiro dia do mês seguinte nos noventa dias posteriores, aquela publicação,..." constantes do artigo 13, todos da Lei Complementar n ${ }^{\text {o } 70, ~ d e ~} 30$ de dezembro de 1991. Relator: Min. Moreira Alves, julgado em 01.12.1993, DJ 16.06.1995. Disponível em http://www.stf.jus.br. Acesso em 30.05.2010.

Supremo Tribunal Federal. ADI 534 (Tribunal Pleno) AÇÃO DIRETA DE INCONSTITUCIONALIDADE - LEI N. 8.024/90 BLOQUEIO DOS CRUZADOS NOVOS - DEVOLUÇÃO INTEGRAL DOS ATIVOS FINANCEIROS RETIDOS - INEXISTÊNCIA DE EFEITOS RESIDUAIS CONCRETOS - NORMAS LEGAIS DE VIGENCIA TEMPORARIA - PLENO EXAURIMENTO DO SEU CONTEUDO EFICACIAL - PREJUDICIALIDADE RECONHECIDA QUESTÃO DE ORDEM ACOLHIDA. - A CESSAÇÃO SUPERVENIENTE DA EFICACIA DA LEI ARGUIDA DE INCONSTITUCIONALIDADE INIBE O PROSSEGUIMENTO DA AÇÃO DIRETA DE INCONSTITUCIONALIDADE, DESDE QUE INEXISTAM EFEITOS RESIDUAIS CONCRETOS, DERIVADOS DA APLICAÇÃO DO ATO ESTATAL IMPUGNADO. PRECEDENTES DO STF. - A EXTINÇÃO ANOMALA DO PROCESSO DE CONTROLE NORMATIVO ABSTRATO, MOTIVADA PELA PERDA SUPERVENIENTE DE SEU OBJETO, TANTO PODE DECORRER DA 
REVOGAÇÃO PURA E SIMPLES DO ATO ESTATAL IMPUGNADO COMO DO EXAURIMENTO DE SUA EFICACIA, TAL COMO SUCEDE NAS HIPÓTESES DE NORMAS LEGAIS DESTINADAS A VIGENCIA TEMPORARIA. - COM A DEVOLUÇÃO INTEGRAL DOS ATIVOS FINANCEIROS RETIDOS, E A CONSEQUENTE CONVERSAO DOS CRUZADOS NOVOS EM CRUZEIROS, EXAURIU-SE,DE MODO DEFINITIVO E IRREVERSIVEL, O CONTEUDO EFICACIAL DAS NORMAS IMPUGNADAS INSCRITAS NA LEI N. 8.024/90. Relator: Min. Celso de Mello, julgado em 26.08.1992, publicado em 08.04.1994. Disponível em http://www.stf.jus.br. Acesso em 30.05.2010.

Supremo Tribunal Federal. ADI 1102 (Tribunal Pleno) AÇÃO DIRETA DE INCONSTITUCIONALIDADE. CUSTEIO DA SEGURIDADE SOCIAL: EXPRESSÕES "EMPRESARIOS" E "AUTONOMOS" CONTIDAS NO INC.I DO ART. 22 DA LEI N. 8.212/91. PEDIDO PREJUDICADO QUANTO AS EXPRESSÕES "AUTONOMOS E ADMINISTRADORES" CONTIDAS NO INC. I DO ART. 3. DA LEI N. 7.787/89. 1. O inciso I do art. 22 da Lei n. 8.212, de 25.07.91, derrogou o inciso I do art. 3. da Lei n. 7.787, de 30.06.89, porque regulou inteiramente a mesma matéria (art. 2., par. 1., da Lei de Introdução ao Cod. Civil). Malgrado esta revogação, o Senado Federal suspendeu a execução das expressões "avulsos, autonomos e administradores" contidas no inc. I do art. 3. da Lei n. 7.787, pela Resolução n. 15, de 19.04.95 (DOU 28.04.95), tendo em vista a decisão desta Corte no RE n. 177.296-4. 2. A contribuição previdenciaria incidente sobre a "folha de salarios" (CF, art. 195, I) não alcanca os "autonomos" e "administradores", sem vinculo empregaticio; entretanto, poderiam ser alcancados por contribuição criada por lei complementar (CF, arts. 195, par. 4., e 154, I). Precedentes. 3. Ressalva do Relator que, invocando politica judicial de conveniencia, concedia efeito prospectivo ou "ex-nunc" a decisão, a partir da concessão da liminar. 4. Ação direta conhecida e julgada procedente para declarar a inconstitucionalidade das expressões "empresários" e "autônomos" contidas no inciso I do art. 22 da Lei n. 8.212, de 25.07.91. Relator: Min. Maurício Corrêa, julgado em 05.10.1995, DJ 17.11.1995. Disponível em http://www.stf.jus.br. Acesso em 30.05.2010.

Supremo Tribunal Federal. ADI 2154. Foram apensados aos da presente ADIn 2154 os autos da ADIn 2258, para processamento conjunto, dada a imbricação parcial dos respectivos objetos, relativos à L. 9688/99 - que "dispõe sobre o processo e julgamento da ação direta de inconstitucionalidade e da ação declaratória de constitucionalidade perante o Supremo Tribunal". A primeira - ADIn 2154, da Confederação Nacional dos Profissionais Liberais -, além de imputar ao diploma ilegítima omissão 
parcial atinente às garantias do contraditório e da ampla defesa no processo da ADC, argúi a inconstitucionalidade dos arts. 26, in fine - no que veda a ação rescisória das decisões definitivas dos processos de controle direto que disciplina - e do art. 27 - que autoriza ao STF a manipulação da eficácia temporal da declaração de inconstitucionalidade. A segunda - ADIn 2258, da Ordem dos Advogados do Brasil -, impugna a validade desse mesmo art. 27 e mais a do art. $11, \S 2^{\circ}$, in fine - que admite possa o Tribunal, ao deferir medida cautelar na ADIn, decidia que não se torne aplicável a legislação anterior - a do art. 21 - que admite consista a medida cautelar na ADC na "determinação de que os juízes e os Tribunais suspendam o julgamento dos processos que envolvam a aplicação da lei ou do ato normativo objeto da ação até seu julgamento definitivo". Em ambas, há pedido cautelar. Já prestadas as informações pelo Congresso Nacional (f. 116 - 161) - com ampla documentação do processo legislativo - e pela Presidência da República - estas, explicitamente adotados pelos Senhor Advogado Nacional e com exauriente defesa da lei questionada - o que dispensa novas informações e a nova audiência da Advocacia- Geral. De qualquer modo, cientificados desta decisão, nada impede que tragam novos elementos de fato ou de direito, que entendam relevantes. Por outro lado, a natureza e a relevância da matéria reclamam rápida e definitiva solução, a evitar que a pendência do processo - sejam quais forem as decisões cautelares liminarmente tomadas - além de prorrogar o período de incerteza jurídica, possa vir a obstruir o andamento de outros processos objetivos ou subjetivos, quiçá urgentes. Valho-me, pois, da alternativa aberta pelo art. 12 da mesma L. 9868/99 - este, não questionado - para pedir o parecer do Senhor Procurador-Geral da República, no prazo legal, de modo a propiciar o julgamento definitivo da ações. Relator: Min. Sepúlveda Pertence, julgado em 24.09.2001, publicado em DJ 02.10.2001 PP-00033). Disponível em http://www.stf.jus.br. Acesso em 30.05.2010.

Supremo Tribunal Federal. ADI 3756 ED (Tribunal Pleno)

CONSTITUCIONAL. AÇÃO DIRETA DE INCONSTITUCIONALIDADE. EMBARGOS DE DECLARAÇÃO. ILEGITIMIDADE RECURSAL DO GOVERNADOR DO DISTRITO FEDERAL. ACOLHIMENTO PARCIAL DOS EMBARGOS MANEJADOS PELA MESA DA CÂMARA DO DISTRITO FEDERAL. 1. Não havendo participado do processo de fiscalização abstrata, na condição de autor ou requerido, o Governador do Distrito Federal carece de legitimidade para fazer uso dos embargos de declaração. Precedentes. 2. No julgamento da ADI 3.756, o Supremo Tribunal Federal deu pela improcedência do pedido. Decisão que, no campo teórico, somente comporta eficácia ex tunc ou retroativa. No plano dos fatos, porém, não há como se exigir que o Poder Legislativo do Distrito Federal se amolde, de modo retroativo, ao julgado da ADI 3.756, porquanto as despesas com pessoal já foram efetivamente realizadas, tudo com base na Decisão $n^{\circ}$ 
9.475/00, do TCDF, e em sucessivas leis de diretrizes orçamentárias. 3. Embargos de declaração parcialmente acolhidos para esclarecer que o fiel cumprimento da decisão plenária na ADI 3.756 se dará na forma do art. 23 da $\operatorname{LC} n^{\circ} 101 / 2000$, a partir da data de publicação da ata de julgamento de mérito da ADI 3.756, e com estrita observância das demais diretrizes da própria Lei de Responsabilidade Fiscal. Relator: Min. Carlos Britto, julgado em 24.10.2007, DJ 23.11.2007. Disponível em http://www.stf.jus.br. Acesso em 30.05.2010.

Supremo Tribunal Federal.ADI 4071 (Tribunal Pleno) Agravo regimental. Ação direta de inconstitucionalidade manifestamente improcedente. Indeferimento da petição inicial pelo Relator. Art. $4^{\circ}$ da Lei $\mathrm{n}^{\mathrm{o}}$ 9.868/99. 1. É manifestamente improcedente a ação direta de inconstitucionalidade que verse sobre norma (art. 56 da Lei $\mathrm{n}^{\circ}$ 9.430/96) cuja constitucionalidade foi expressamente declarada pelo Plenário do Supremo Tribunal Federal, mesmo que em recurso extraordinário. 2. Aplicação do art. $4^{\circ}$ da Lei ${ }^{\circ}$ 9.868/99, segundo o qual "a petição inicial inepta, não fundamentada e a manifestamente improcedente serão liminarmente indeferidas pelo relator". 3. A alteração da jurisprudência pressupõe a ocorrência de significativas modificações de ordem jurídica, social ou econômica, ou, quando muito, a superveniência de argumentos nitidamente mais relevantes do que aqueles antes prevalecentes, o que não se verifica no caso. 4. O amicus curiae somente pode demandar a sua intervenção até a data em que o Relator liberar o processo para pauta. 5. Agravo regimental a que se nega provimento. Relator: Min.Menezes Direito, julgado em 22.04.2009, DJe-195 DIVULG 15.10.2009. Disponível em http://www.stf.jus.br. Acesso em 30.05.2010.

. Supremo Tribunal Federal. AI 241397 AgR (2a Turma) RECURSO DE AGRAVO - RECURSO EXTRAORDINÁRIO CORRETAMENTE DENEGADO NA ORIGEM- FGTS - CORREÇÃO MONETÁRIA - MATÉRIA INFRACONSTITUCIONAL - HIPÓTESE DE OFENSA REFLEXA - INADMISSIBILIDADE DO APELO EXTREMO AGRAVO IMPROVIDO. SOMENTE O CONFLITO DIRETO E IMEDIATO COM O TEXTO DA CONSTITUIÇÃO FEDERAL ENSEJA A INTERPOSIÇÃO DE RECURSO EXTRAORDINÁRIO. - O exame da matéria em debate - correção monetária das contas vinculadas do FGTS reclama a necessária análise de diplomas normativos de caráter infraconstitucional. A alegada ofensa à Constituição, acaso existente, apresentar-se-ia por via reflexa, por exigir - para efeito de seu reconhecimento - confronto prévio da legislação comum com o texto constitucional, circunstância esta que, por si só, basta para inviabilizar o conhecimento do recurso extraordinário. Precedentes. RAZÕES DE ESTADO NÃO PODEM SER INVOCADAS PARA JUSTIFICAR O 
DESCUMPRIMENTO DA CONSTITUIÇÃO. - É preciso advertir que as razões de Estado - quando invocadas como argumento de sustentação da pretensão jurídica do Poder Público ou de qualquer outra instituição representam expressão de um perigoso ensaio destinado a submeter, à vontade do Príncipe (o que é intolerável), a autoridade hierárquiconormativa da própria Constituição da República, comprometendo, desse modo, a idéia de que o exercício do poder estatal, quando praticado sob a égide de um regime democrático, está permanentemente exposto ao controle social dos cidadãos e à fiscalização de ordem jurídicoconstitucional dos magistrados e Tribunais. Relator: Min. Celso de Mello, julgado em 10.08.1999, DJ 17.09.1999. Disponível em http://www.stf.jus.br. Acesso em 30.05.2010.

Supremo Tribunal Federal. AI 478398 AgR-ED (1 $1^{\text {a }}$ Turma)

EMBARGOS DE DECLARAÇÃO EM AGRAVO REGIMENTAL EM AGRAVO DE INSTRUMENTO. PRESTAR ESCLARECIMENTOS. 1. O artigo 27 da Lei n. 9.868/99 só tem aplicação no controle concentrado de constitucionalidade. Precedentes. 2. Norma municipal anterior à Constituição de 1988. Não houve declaração de inconstitucionalidade, mas declaração de que a mesma não foi recebida pela nova ordem constitucional, que surte efeitos a partir da promulgação da Constituição de 1988. Embargos de declaração acolhidos apenas para prestar esclarecimentos. Relator: Min. Eros Grau, julgado em 22.06.2005, DJ 05.08.2005. Disponível em http://www.stf.jus.br. Acesso em 30.05.2010.

Supremo Tribunal Federal. AI 521546 AgR-ED (1 ${ }^{\text {a }}$ Turma) Embargos de declaração acolhidos, apenas, para prestar os seguintes esclarecimentos: 1. Já decidiu o STF (v.g. 1 ${ }^{\text {a }}$ T., RE-AgR 430.421, Cezar Peluso, DJ 04.02.2005 e AI-AgR 428.886, Eros Grau, DJ 25.2005), que o artigo 27 da L. 9.868/99 só tem aplicação no controle concentrado de constitucionalidade. 2. No caso - norma municipal anterior à Constituição de 1988 - não houve declaração de inconstitucionalidade, mas declaração de que a mesma não foi recebida pela nova ordem constitucional, que surte efeitos a partir da promulgação da Constituição Federal. Relator: Min. Sepúlveda Pertence, julgado em 26.04.2005, DJ 13.05.2005. Disponível em http://www.stf.jus.br. Acesso em 30.05.2010.

Supremo Tribunal Federal. AI 582280 AgR (2 ${ }^{\mathrm{a}}$ Turma) RECURSO EXTRAORDINÁRIO INTERPOSTO PELO MUNICÍPIO DO RIO DE JANEIRO/RJ - PLEITO RECURSAL QUE BUSCA A APLICAÇÃO, NO CASO, DA TÉCNICA DA MODULAÇÃO DOS EFEITOS TEMPORAIS DA DECLARAÇÃO DE INCONSTITUCIONALIDADE - IMPOSSIBILIDADE, PELO FATO DE O SUPREMO TRIBUNAL FEDERAL NÃO HAVER PROFERIDO 
DECISÃO DE INCONSTITUCIONALIDADE PERTINENTE AO ATO ESTATAL QUESTIONADO - JULGAMENTO DA SUPREMA CORTE QUE SE LIMITOU A FORMULAR, NA ESPÉCIE, MERO JUÍZO NEGATIVO DE RECEPÇÃO - NÃO-RECEPÇÃO E INCONSTITUCIONALIDADE: NOÇÕES CONCEITUAIS QUE NÃO SE CONFUNDEM - RECURSO IMPROVIDO. 1. CONSIDERAÇÕES SOBRE O VALOR DO ATO INCONSTITUCIONAL - OS DIVERSOS GRAUS DE INVALIDADE DO ATO EM CONFLITO COM A CONSTITUIÇÃO: ATO INEXISTENTE? ATO NULO? ATO ANULÁVEL (COM EFICÁCIA "EX TUNC" OU COM EFICÁCIA "EX NUNC")? - FORMULAÇÕES TEÓRICAS - O "STATUS QUAESTIONIS" NA JURISPRUDÊNCIA DO SUPREMO TRIBUNAL FEDERAL. 2. MODULAÇÃO TEMPORAL DOS EFEITOS DA DECISÃO DE INCONSTITUCIONALIDADE: TÉCNICA INAPLICÁVEL QUANDO SE TRATAR DE JUÍZO NEGATIVO DE RECEPÇÃO DE ATOS PRÉ-CONSTITUCIONAIS. - A declaração de inconstitucionalidade reveste-se, ordinariamente, de eficácia "ex tunc" (RTJ 146/461-462 - RTJ 164/506-509), retroagindo ao momento em que editado o ato estatal reconhecido inconstitucional pelo Supremo Tribunal Federal. O Supremo Tribunal Federal tem reconhecido, excepcionalmente, a possibilidade de proceder à modulação ou limitação temporal dos efeitos da declaração de inconstitucionalidade, mesmo quando proferida, por esta Corte, em sede de controle difuso. Precedente: RE 197.917/SP, Rel. Min. MAURÍCIO CORRÊA (Pleno). - Revela-se inaplicável, no entanto, a teoria da limitação temporal dos efeitos, se e quando o Supremo Tribunal Federal, ao julgar determinada causa, nesta formular juízo negativo de recepção, por entend er que certa lei pré-constitucional mostra-se materialmente incompatível com normas constitucionais a ela supervenientes. - A nãorecepção de ato estatal pré-constitucional, por não implicar a declaração de sua inconstitucionalidade - mas o reconhecimento de sua pura e simples revogação (RTJ 143/355 - RTJ 145/339) -, descaracteriza um dos pressupostos indispensáveis à utilização da técnica da modulação temporal, que supõe, para incidir, dentre outros elementos, a necessária existência de um juízo de inconstitucionalidade. - Inaplicabilidade, ao caso em exame, da técnica da modulação dos efeitos, por tratar-se de diploma legislativo, que, editado em 1984, não foi recepcionado, no ponto concernente à norma questionada, pelo vigente ordenamento constitucional. Relator: Min. Celso de Mello, julgado em 12.09.2006, DJ 06.11.2006. Disponível em http://www.stf.jus.br. Acesso em 30.05.2010.

Supremo Tribunal Federal. AI 655047AgR ( $1^{\text {a }}$ Turma) CONSTITUCIONAL. TRIBUTÁRIO. IPTU DO MUNICÍPIO DO RIO DE JANEIRO. PROGRESSIVIDADE ANTERIOR À EC 29/2000. TAXA DE COLETA DE LIXO E LIMPEZA PÚBLICA - TCLLP E TAXA DE ILUMINAÇÃO PÚBLICA - TIP. EFEITOS DA DECLARAÇÃO DE 
INCONSTITUCIONALIDADE NO CONTROLE DIFUSO. MULTA. AGRAVO IMPROVIDO. I - A atribuição de efeitos prospectivos à declaração de inconstitucionalidade, dado o seu caráter excepcional, somente tem cabimento quando o tribunal manifesta-se expressamente sobre o tema, observando-se a exigência de quorum qualificado previsto em lei. II - Aplicação de multa. III - Agravo Regimental improvido. Relator: Min. Ricardo Lewandowski, julgado em 27.05.2008, DJe-107 DIVULG 12.06.2008 PUBLIC 13.06.2008. Disponível em http://www.stf.jus.br. Acesso em 30.05.2010.

Supremo Tribunal Federal. CC 7204 (Tribunal Pleno) CONSTITUCIONAL. COMPETÊNCIA JUDICANTE EM RAZÃO DA MATÉRIA. AÇÃO DE INDENIZAÇÃO POR DANOS MORAIS E PATRIMONIAIS DECORRENTES DE ACIDENTE DO TRABALHO, PROPOSTA PELO EMPREGADO EM FACE DE SEU (EX) EMPREGADOR. COMPETÊNCIA DA JUSTIÇA DO TRABALHO. ART. 114 DA MAGNA CARTA. REDAÇÃO ANTERIOR E POSTERIOR À EMENDA CONSTITUCIONAL Nº 45/04. EVOLUÇÃO DA JURISPRUDÊNCIA DO SUPREMO TRIBUNAL FEDERAL. PROCESSOS EM CURSO NA JUSTIÇA COMUM DOS ESTADOS. IMPERATIVO DE POLÍTICA JUDICIÁRIA. Numa primeira interpretação do inciso I do art. 109 da Carta de Outubro, o Supremo Tribunal Federal entendeu que as ações de indenização por danos morais e patrimoniais decorrentes de acidente do trabalho, ainda que movidas pelo empregado contra seu (ex-)empregador, eram da competência da Justiça comum dos Estados-Membros. 2. Revisando a matéria, porém, o Plenário concluiu que a Lei Republicana de 1988 conferiu tal competência à Justiça do Trabalho. Seja porque $\mathrm{o}$ art. 114, já em sua redação originária, assim deixava transparecer, seja porque aquela primeira interpretação do mencionado inciso I do art. 109 estava, em boa verdade, influenciada pela jurisprudência que se firmou na Corte sob a égide das Constituições anteriores. 3. Nada obstante, como imperativo de política judiciária -- haja vista o significativo número de ações que já tramitaram e ainda tramitam nas instâncias ordinárias, bem como o relevante interesse social em causa --, o Plenário decidiu, por maioria, que o marco temporal da competência da Justiça trabalhista é o advento da EC 45/04. Emenda que explicitou a competência da Justiça Laboral na matéria em apreço. 4. A nova orientação alcança os processos em trâmite pela Justiça comum estadual, desde que pendentes de julgamento de mérito. É dizer: as ações que tramitam perante a Justiça comum dos Estados, com sentença de mérito anterior à promulgação da EC 45/04, lá continuam at é o trânsito em julgado e correspondente execução. Quanto àquelas cujo mérito ainda não foi apreciado, hão de ser remetidas à Justiça do Trabalho, no estado em que se encontram, com total aproveitamento dos atos praticados até então. A medida se impõe, em razão das características que distinguem a Justiça comum estadual e a Justiça do Trabalho, cujos sistemas recursais, órgãos e instâncias não guardam exata 
correlação. 5. O Supremo Tribunal Federal, guardião-mor da Constituição Republicana, pode e deve, em prol da segurança jurídica, atribuir eficácia prospectiva às suas decisões, com a delimitação precisa dos respectivos efeitos, toda vez que proceder a revisões de jurisprudência definidora de competência ex ratione materiae. $\mathrm{O}$ escopo é preservar os jurisdicionados de alterações jurisprudenciais que ocorram sem mudança formal do Magno Texto. 6. Aplicação do precedente consubstanciado no julgamento do Inquérito 687, Sessão Plenária de 25.08.99, ocasião em que foi cancelada a Súmula 394 do STF, por incompatível com a Constituição de 1988, ressalvadas as decisões proferidas na vigência do verbete. 7. Conflito de competência que se resolve, no caso, com o retorno dos autos ao Tribunal Superior do Trabalho. Relator: Min. Carlos Britto, julgado em 29.06.2005, DJ 09.12.2005. Disponível em http://www.stf.jus.br. Acesso em 30.05.2010.

Supremo Tribunal Federal. HC 82959 (Tribunal Pleno) PENA - REGIME DE CUMPRIMENTO - PROGRESSÃO - RAZÃO DE SER. A progressão no regime de cumprimento da pena, nas espécies fechado, semi-aberto e aberto, tem como razão maior a ressocialização do preso que, mais dia ou menos dia, voltará ao convívio social. PENA CRIMES HEDIONDOS - REGIME DE CUMPRIMENTO PROGRESSÃO - ÓBICE - ARTIGO $2^{\circ}, \S 1^{\circ}$, DA LEI N $\mathrm{N}^{\circ} 8.072 / 90$ INCONSTITUCIONALIDADE - EVOLUÇÃO JURISPRUDENCIAL. Conflita com a garantia da individualização da pena - artigo $5^{\circ}$, inciso XLVI, da Constituição Federal - a imposição, mediante norma, do cumprimento da pena em regime integralmente fechado. Nova inteligência do princípio da individualização da pena, em evolução jurisprudencial, assentada a inconstitucionalidade do artigo $2^{\circ}$, $\S 1^{\circ}$, da Lei $\mathrm{n}^{\circ} 8.072 / 90$. Relator: Min. Marco Aurélio, julgado em 23.02.2006, DJ 01.09.2006. Disponível em http://www.stf.jus.br. Acesso em 30.05.2010.

Supremo Tribunal Federal. MS 26603 (Tribunal Pleno) MANDADO DE SEGURANÇA - QUESTÕES PRELIMINARES REJEITADAS - O MANDADO DE SEGURANÇA COMO PROCESSO DOCUMENTAL E A NOÇÃO DE DIREITO LÍQUIDO E CERTO NECESSIDADE DE PROVA PRÉ-CONSTITUÍDA - A COMPREENSÃO DO CONCEITO DE AUTORIDADE COATORA, PARA FINS MANDAMENTAIS - RESERVA ESTATUTÁRIA, DIREITO AO PROCESSO E EXERCÍCIO DA JURISDIÇÃO - INOPONIBILIDADE, AO PODER JUDICIÁRIO, DA RESERVA DE ESTATUTO, QUANDO INSTAURADO LITÍGIO CONSTITUCIONAL EM TORNO DE ATOS PARTIDÁRIOS "INTERNA CORPORIS" - COMPETÊNCIA NORMATIVA DO TRIBUNAL SUPERIOR ELEITORAL - O INSTITUTO DA "CONSULTA" NO ÂMBITO DA JUSTIÇA 
ELEITORAL: NATUREZA E EFEITOS JURÍDICOS - POSSIBILIDADE DE O TRIBUNAL SUPERIOR ELEITORAL, EM RESPOSTA À CONSULTA, NELA EXAMINAR TESE JURÍDICA EM FACE DA CONSTITUIÇÃO DA REPÚBLICA - CONSULTA/TSE N ${ }^{\circ}$ 1.398/DF FIDELIDADE PARTIDÁRIA - A ESSENCIALIDADE DOS PARTIDOS POLÍTICOS NO PROCESSO DE PODER - MANDATO ELETIVO VÍNCULO PARTIDÁRIO E VÍNCULO POPULAR - INFIDELIDADE PARTIDÁRIA - CAUSA GERADORA DO DIREITO DE A AGREMIAÇÃO PARTIDÁRIA PREJUDICADA PRESERVAR A VAGA OBTIDA PELO SISTEMA PROPORCIONAL - HIPÓTESES EXCEPCIONAIS QUE LEGITIMAM O ATO DE DESLIGAMENTO PARTIDÁRIO - POSSIBILIDADE, EM TAIS SITUAÇÕES, DESDE QUE CONFIGURADA A SUA OCORRÊNCIA, DE O PARLAMENTAR, NO ÂMBITO DE PROCEDIMENTO DE JUSTIFICAÇÃO INSTAURADO PERANTE A JUSTIÇA ELEITORAL, MANTER A INTEGRIDADE DO MANDATO LEGISLATIVO - NECESSÁRIA OBSERVÂNCIA, NO PROCEDIMENTO DE JUSTIFICAÇÃO, DO PRINCÍPIO DO "DUE PROCESS OF LAW" (CF, ART. $5^{\circ}$, INCISOS LIV E LV) - APLICAÇÃO ANALÓGICA DOS ARTS. $3^{\circ}$ A $7^{\circ}$ DA LEI COMPLEMENTAR $\mathrm{N}^{\circ}$ 64/90 AO REFERIDO PROCEDIMENTO DE JUSTIFICAÇÃO - ADMISSIBILIDADE DE EDIÇÃO, PELO TRIBUNAL SUPERIOR ELEITORAL, DE RESOLUÇÃO QUE REGULAMENTE O PROCEDIMENTO DE JUSTIFICAÇÃO - MARCO INICIAL DA EFICÁCIA DO PRONUNCIAMENTO DESTA SUPREMA CORTE NA MATÉRIA: DATA EM QUE O TRIBUNAL SUPERIOR ELEITORAL APRECIOU A CONSULTA N ${ }^{\circ} 1.398 /$ DF - OBEDIÊNCIA AO POSTULADO DA SEGURANÇA JURÍDICA - A SUBSISTÊNCIA DOS ATOS ADMINISTRATIVOS E LEGISLATIVOS PRATICADOS PELOS PARLAMENTARES INFIÉIS: CONSEQÜÊNCIA DA APLICAÇÃO DA TEORIA DA INVESTIDURA APARENTE - O PAPEL DO SUPREMO TRIBUNAL FEDERAL NO EXERCÍCIO DA JURISDIÇÃO CONSTITUCIONAL E A RESPONSABILIDADE POLÍTICO-JURÍDICA QUE LHE INCUMBE NO PROCESSO DE VALORIZAÇÃO DA FORÇA NORMATIVA DA CONSTITUIÇÃO - O MONOPÓLIO DA "ÚLTIMA PALAVRA", PELA SUPREMA CORTE, EM MATÉRIA DE INTERPRETAÇÃO CONSTITUCIONAL MANDADO DE SEGURANÇA INDEFERIDO. PARTIDOS POLÍTICOS E ESTADO DEMOCRÁTICO DE DIREITO. - A Constituição da República, ao delinear os mecanismos de atuação do regime democrático e ao proclamar os postulados básicos concernentes às instituições partidárias, consagrou, em seu texto, o próprio estatuto jurídico dos partidos políticos, definindo princípios, que, revestidos de estatura jurídica incontrastável, fixam diretrizes normativas e instituem vetores condicionantes da organização e funcionamento das agremiações partidárias. Precedentes. - A normação constitucional dos partidos políticos - que concorrem para a formação da vontade política do povo - tem por objetivo regular e 
disciplinar, em seus aspectos gerais, não só o processo de institucionalização desses corpos intermediários, como também assegurar o acesso dos cidadãos ao exercício do poder estatal, na medida em que pertence às agremiações partidárias - e somente a estas - o monopólio das candidaturas aos cargos eletivos. - A essencialidade dos partidos políticos, no Estado de Direito, tanto mais se acentua quando se tem em consideração que representam eles um instrumento decisivo na concretização do princípio democrático e exprimem, na perspectiva do contexto histórico que conduziu à sua formação e institucionalização, um dos meios fundamentais no processo de legitimação do poder estatal, na exata medida em que o Povo - fonte de que emana a soberania nacional - tem, nessas agremiações, o veículo necessário ao desempenho das funções de regência política do Estado. As agremiações partidárias, como corpos intermediários que são, posicionando-se entre a sociedade civil e a sociedade política, atuam como canais institucionalizados de expressão dos anseios políticos e das reivindicações sociais dos diversos estratos e correntes de pensamento que se manifestam no seio da comunhão nacional. A NATUREZA PARTIDÁRIA DO MANDATO REPRESENTATIVO TRADUZ EMANAÇÃO DA NORMA CONSTITUCIONAL QUE PREVÊ O "SISTEMA PROPORCIONAL". - O mandato representativo não constitui projeção de um direito pessoal titularizado pelo parlamentar eleito, mas representa, ao contrário, expressão que deriva da indispensável vinculação do candidato ao partido político, cuja titularidade sobre as vagas conquistadas no processo eleitoral resulta de "fundamento constitucional autônomo", identificável tanto no art. 14, $\S 3^{\circ}$, inciso $\mathrm{V}$ (que define a filiação partidária como condição de elegibilidade) quanto no art. 45, "caput" (que consagra o "sistema proporcional"), da Constituição da República. - O sistema eleitoral proporcional: um modelo mais adequado ao exercício democrático do poder, especialmente porque assegura, às minorias, o direito de representação e viabiliza, às correntes políticas, o exercício do direito de oposição parlamentar. Doutrina. - A ruptura dos vínculos de caráter partidário e de índole popular, provocada por atos de infidelidade do representante eleito (infidelidade ao partido e infidelidade ao povo), subverte o sentido das instituições, ofende o senso de responsabilidade política, traduz gesto de deslealdade para com as agremiações partidárias de origem, compromete o modelo de representação popular e frauda, de modo acintoso e reprovável, a vontade soberana dos cidadãos eleitores, introduzindo fatores de desestabilização na prática do poder e gerando, como imediato efeito perverso, a deformação da ética de governo, com projeção vulneradora sobre a própria razão de ser e os fins visados pelo sistema eleitoral proporcional, tal como previsto e consagrado pela Constituição da República. A INFIDELIDADE PARTIDÁRIA COMO GESTO DE DESRESPEITO AO POSTULADO DEMOCRÁTICO. - A exigência de fidelidade partidária traduz e reflete valor constitucional impregnado de elevada significação político- -jurídica, cuja observância, pelos detentores de mandato legislativo, representa expressão de respeito 
tanto aos cidadãos que os elegeram (vínculo popular) quanto aos partidos políticos que lhes propiciaram a candidatura (vínculo partidário). - $\mathrm{O}$ ato de infidelidade, seja ao partido político, seja, com maior razão, ao próprio cidadão-eleitor, constitui grave desvio ético-político, além de representar inadmissível ultraje ao princípio democrático e ao exercício legítimo do poder, na medida em que migrações inesperadas, nem sempre motivadas por justas razões, não só surpreendem o próprio corpo eleitoral e as agremiações partidárias de origem - desfalcando-as da representatividade por elas conquistada nas urnas -, mas culminam por gerar um arbitrário desequilíbrio de forças no Parlamento, vindo, até, em clara fraude à vontade popular e em frontal transgressão ao sistema eleitoral proporcional, a asfixiar, em face de súbita redução numérica, o exercício pleno da oposição política. A prática da infidelidade partidária, cometida por detentores de mandato parlamentar, por implicar violação ao sistema proporcional, mutila o direito das minorias que atuam no âmbito social, privando-as de representatividade nos corpos legislativos, e ofende direitos essenciais notadamente o direito de oposição - que derivam dos fundamentos que dão suporte legitimador ao próprio Estado Democrático de Direito, tais como a soberania popular, a cidadania e o pluralismo político (CF, art. $1^{\circ}$, I, II e V). - A repulsa jurisdicional à infidelidade partidária, além de prestigiar um valor eminentemente constitucional ( $\mathrm{CF}$, art. 17, $\S 1^{\circ}$, "in fine"), (a) preserva a legitimidade do processo eleitoral, (b) faz respeitar a vontade soberana do cidadão, (c) impede a deformação do modelo de representação popular, (d) assegura a finalidade do sistema eleitoral proporcional, (e) valoriza e fortalece as organizações partidárias e (f) confere primazia à fidelidade que o Deputado eleito deve observar em relação ao corpo eleitoral e ao próprio partido sob cuja legenda disputou as eleições. HIPÓTESES EM QUE SE LEGITIMA, EXCEPCIONALMENTE, O VOLUNTÁRIO DESLIGAMENTO PARTIDÁRIO. - O parlamentar, não obstante faça cessar, por sua própria iniciativa, os vínculos que o uniam ao partido sob cuja legenda foi eleito, tem o direito de preservar o mandato que lhe foi conferido, se e quando ocorrerem situações excepcionais que justifiquem esse voluntário desligamento partidário, como, p. ex., nos casos em que se demonstre "a existência de mudança significativa de orientação programática do partido" ou "em caso de comprovada perseguição política dentro do partido que abandonou" (Min. Cezar Peluso). A INSTAURAÇÃO, PERANTE A JUSTIÇA ELEITORAL, DE PROCEDIMENTO DE JUSTIFICAÇÃO. - O Tribunal Superior Eleitoral, no exercício da competência normativa que lhe é atribuída pelo ordenamento positivo, pode, validamente, editar resolução destinada a disciplinar o procedimento de justificação, instaurável perante órgão competente da Justiça Eleitoral, em ordem a estruturar, de modo formal, as fases rituais desse mesmo procedimento, valendo-se, para tanto, se assim o entender pertinente, e para colmatar a lacuna normativa existente, da "analogia legis", mediante aplicação, no que couber, das normas inscritas nos arts. $3^{\circ}$ a $7^{\circ}$ da Lei Complementar $n^{\circ}$ 64/90. - Com esse procedimento 
de justificação, assegura-se, ao partido político e ao parlamentar que dele se desliga voluntariamente, a possibilidade de demonstrar, com ampla dilação probatória, perante a própria Justiça Eleitoral - e com pleno respeito ao direito de defesa $\left(\mathrm{CF}\right.$, art. $5^{\circ}$, inciso $\left.\mathrm{LV}\right)$-, a ocorrência, ou não, de situações excepcionais legitimadoras do desligamento partidário do parlamentar eleito (Consulta TSE $n^{\circ} 1.398 / \mathrm{DF}$ ), para que se possa, se e quando for o caso, submeter, ao Presidente da Casa legislativa, o requerimento de preservação da vaga obtida nas eleições proporcionais. INFIDELIDADE PARTIDÁRIA E LEGITIMIDADE DOS ATOS LEGISLATIVOS PRATICADOS PELO PARLAMENTAR INFIEL. A desfiliação partidária do candidato eleito e a sua filiação a partido diverso daquele sob cuja legenda se elegeu, ocorridas sem justo motivo, assim reconhecido por órgão competente da Justiça Eleitoral, embora configurando atos de transgressão à fidelidade partidária - o que permite, ao partido político prejudicado, preservar a vaga até então ocupada pelo parlamentar infiel -, não geram nem provocam a invalidação dos atos legislativos e administrativos, para cuja formação concorreu, com a integração de sua vontade, esse mesmo parlamentar. Aplicação, ao caso, da teoria da investidura funcional aparente. Doutrina. Precedentes. REVISÃO JURISPRUDENCIAL E SEGURANÇA JURÍDICA: A INDICAÇÃO DE MARCO TEMPORAL DEFINIDOR DO MOMENTO INICIAL DE EFICÁCIA DA NOVA ORIENTAÇÃO PRETORIANA. - Os precedentes firmados pelo Supremo Tribunal Federal desempenham múltiplas e relevantes funções no sistema jurídico, pois lhes cabe conferir previsibilidade às futuras decisões judiciais nas matérias por eles abrangidas, atribuir estabilidade às relações jurídicas constituídas sob a sua égide e em decorrência deles, gerar certeza quanto à validade dos efeitos decorrentes de atos praticados de acordo com esses mesmos precedentes e preservar, assim, em respeito à ética do Direito, a confiança dos cidadãos nas ações do Estado. - Os postulados da segurança jurídica e da proteção da confiança, enquanto expressões do Estado Democrático de Direito, mostram-se impregnados de elevado conteúdo ético, social e jurídico, projetando-se sobre as relações jurídicas, inclusive as de direito público, sempre que se registre alteração substancial de diretrizes hermenêuticas, impondo-se à observância de qualquer dos Poderes do Estado e, desse modo, permitindo preservar situações já consolidadas no passado e anteriores aos marcos temporais definidos pelo próprio Tribunal. Doutrina. Precedentes. - A ruptura de paradigma resultante de substancial revisão de padrões jurisprudenciais, com o reconhecimento do caráter partidário do mandato eletivo proporcional, impõe, em respeito à exigência de segurança jurídica e ao princípio da proteção da confiança dos cidadãos, que se defina o momento a partir do qual terá aplicabilidade a nova diretriz hermenêutica. - Marco temporal que o Supremo Tribunal Federal definiu na matéria ora em julgamento: data em que o Tribunal Superior Eleitoral apreciou a Consulta ${ }^{\circ}$ 1.398/DF (27/03/2007) e, nela, respondeu, em tese, à indagação que lhe foi submetida. A FORÇA NORMATIVA DA CONSTITUIÇÃO E 
O MONOPÓLIO DA ÚLTIMA PALAVRA, PELO SUPREMO TRIBUNAL FEDERAL, EM MATÉRIA DE INTERPRETAÇÃO CONSTITUCIONAL. - O exercício da jurisdição constitucional, que tem por objetivo preservar a supremacia da Constituição, põe em evidência a dimensão essencialmente política em que se projeta a atividade institucional do Supremo Tribunal Federal, pois, no processo de indagação constitucional, assenta-se a magna prerrogativa de decidir, em última análise, sobre a própria substância do poder. - No poder de interpretar a Lei Fundamental, reside a prerrogativa extraordinária de (re)formulá-la, eis que a interpretação judicial acha-se compreendida entre os processos informais de mutação constitucional, a significar, portanto, que "A Constituição está em elaboração permanente nos Tribunais incumbidos de aplicá-la". Doutrina. Precedentes. - A interpretação constitucional derivada das decisões proferidas pelo Supremo Tribunal Federal - a quem se atribuiu a função eminente de "guarda da Constituição" (CF, art. 102, "caput") assume papel de fundamental importância na organização institucional do Estado brasileiro, a justificar o reconhecimento de que o modelo políticojurídico vigente em nosso País conferiu, à Suprema Corte, a singular prerrogativa de dispor do monopólio da última palavra em tema de exegese das normas inscritas no texto da Lei Fundamental. Relator: Min. Celso de Mello, julgado em 04.10.2007, DJe-241 DIVULG 18.12.2008 PUBLIC 19.12.2008. Disponível em http://www.stf.jus.br. Acesso em 30.05.2010.

$\begin{array}{lllll} & & & \\ \text { QUESTÃO } & \text { Supremo Tribunal Federal. Rcl } 1880 & \text { AgR (Tribunal Pleno) } \\ \text { DE } & \text { ORDEM. AÇÃO DIRETA DE DE }\end{array}$ INCONSTITUCIONALIDADE. JULGAMENTO DE MÉRITO. PARÁGRAFO ÚNICO DO ARTIGO 28 DA LEI 9868/99: CONSTITUCIONALIDADE. EFICÁCIA VINCULANTE DA DECISÃO. REFLEXOS. RECLAMAÇÃO. LEGITIMIDADE ATIVA. $1 . \quad$ É constitucional lei ordinária que define como de eficácia vinculante os julgamentos definitivos de mérito proferidos pelo Supremo Tribunal Federal em ação direta de inconstitucionalidade (Lei 9868/99, artigo 28, parágrafo único). 2. Para efeito de controle abstrato de constitucionalidade de lei ou ato normativo, há similitude substancial de objetos nas ações declaratória de constitucionalidade e direta de inconstitucionalidade. Enquanto a primeira destina-se à aferição positiva de constitucionalidade a segunda traz pretensão negativa. Espécies de fiscalização objetiva que, em ambas, traduzem manifestação definitiva do Tribunal quanto à conformação da norma com a Constituição Federal. 3. A eficácia vinculante da ação declaratória de constitucionalidade, fixada pelo $\S 2^{\circ}$ do artigo 102 da Carta da República, não se distingue, em essência, dos efeitos das decisões de mérito proferidas nas ações diretas de inconstitucionalidade. 4. Reclamação. Reconhecimento de legitimidade ativa ad causam de todos que comprovem prejuízo oriundo de decisões dos órgãos do Poder Judiciário, bem como da Administração Pública de todos os níveis, contrárias ao julgado do 
Tribunal. Ampliação do conceito de parte interessada (Lei 8038/90, artigo 13). Reflexos processuais da eficácia vinculante do acórdão a ser preservado. 5. Apreciado o mérito da ADI 1662-SP (DJ de 30.08.01), está o Município legitimado para propor reclamação. Agravo regimental provido. Relator: Min. Maurício Corrêa, julgado em 07.11.2002, DJ 19.03.2004. Disponível em http://www.stf.jus.br. Acesso em 30.05.2010.

Supremo Tribunal Federal. RE $79343 \quad\left(2^{\mathrm{a}}\right.$ Turma $)$ FEDERAL, DA INCONSTITUCIONALIDADE DO DEC.-LEI N. 322, DE 7 DE ABRIL DE 1967 (RTJ 44/54). ACÓRDÃO QUE, NÃO OBSTANTE ESSA DECISÃO, APLICOU, EM FAVOR DO LOCADOR, REGRAS CONTIDAS NESSE ATO LEGISLATIVO. NATUREZA DA DECISÃO QUE PRONUNCIA A INCONSTITUCIONALIDADE DE LEI. SEU CARÁTER CONSTITUTIVO E SUA EFICACIA RETROATIVA. CASO EM QUE NÃO HÁ FALAR-SE NA PRESUNÇÃO, EM QUE SE ACHARIA O AGENTE, DE HAVER CONCLUIDO CONTRATO SOB A PROTEÇÃO DA LEI DECLARADA INCONSTITUCIONAL. RECURSO EXTRAORDINÁRIO CONHECIDO E PROVIDO. Relator: Min. Leitão de Abreu, Brasília, julgado em 31.05.1977, DJ 02.09.1977. Disponível em http://www.stf.jus.br. Acesso em 30.05.2010.

Supremo Tribunal Federal. RE $78209 \quad\left(1^{\text {a }}\right.$ Turma $)$. OFICIAIS DE JUSTIÇA - EXERCÍCIO DE SUAS FUNÇÕES POR AGENTES DO EXECUTIVO. I - MESMO DECLARADA A INCONSTITUCIONALIDADE DA LEI QUE COLOCOU AGENTES DO EXECUTIVO A DISPOSIÇÃO DOS JUIZES, PARA EXERCÍCIO DAS FUNÇÕES DE OFICIAIS DE JUSTIÇA, ESSES SERVENTUARIOS NÃO SÃO USURPADORES, MAS FUNCIONÁRIOS DO ESTADO COM DEFEITO DE COMPETÊNCIA. II - SE O DIREITO RECONHECE A VALIDADE DOS ATOS ATÉ DE FUNCIONÁRIOS DE FATO, ESTRANHOS AOS QUADROS DO PESSOAL PÚBLICO, COM MAIOR RAZÃO HÁ DE RECONHECE-LA SE PRATICADOS POR AGENTES DO ESTADO NO EXERCÍCIO DAQUELAS ATRIBUIÇÕES POR FORÇA DE LEI, QUE VEIO A SER DECLARADA INCONSTITUCIONAL. III - E VALIDA A PENHORA FEITA POR AGENTES DO EXECUTIVO, SOB AS ORDENS DOS JUIZES, NOS TERMOS DA LEI ESTADUAL DE SÃO PAULO, S/N, DE 3.12.1971, MORMENTE SE NENHUM PREJUIZO DISSO ADVEIO PARA O EXECUTADO. Relator: Min. Aliomar Baleeiro, Brasília, julgado em 04.06.1974, DJ 11.10.1974. Disponível em http://www.stf.jus.br. Acesso em 30.05.2010. 
Supremo Tribunal Federal. RE $78533 \quad 2^{\mathrm{a}}$ Turma $)$ ADMINISTRATIVO. FUNCIONÁRIO DE FATO. INVESTIDURA BASEADA EM NORMA POSTERIORMENTE DECLARADA INCONSTITUCIONAL. A NULIDADE NÃO ENVOLVE UMA DAS FASES DE ATO COMPLEXO, DE MERA EXECUÇÃO DE ORDEM LEGITIMA, COM A SUA CONSEQUENCIA NORMAL E ROTINEIRA. APARENCIA DE LEGALIDADE E INEXISTÊNCIA DE PREJUIZO. RECURSO EXTRAORDINÁRIO, PELA LETRA "C" DO ART. 119, III, DA CONSTITUIÇÃO, NÃO CONHECIDO. Relator: Min. Firmino Paz, julgado em 13.11.1981, DJ 26.02.1982. Disponível em http://www.stf.jus.br. Acesso em 30.05.2010.

Supremo Tribunal Federal. RE $78594 \quad\left(2^{\mathrm{a}}\right.$ Turma $)$ FUNCIONÁRIO PÚBLICO. EXERCÍCIO DA FUNÇÃO DE OFICIAL VALIDADE DO ATO PRATICADO POR FUNCIONÁRIO DE FATO. APESAR DE PROCLAMADA A ILEGALIDADE DA INVESTIDURA DO FUNCIONÁRIO PÚBLICO NA FUNÇÃO DE OFICIAL DE JUSTIÇA, EM RAZÃO DA DECLARAÇÃO DE INCONSTITUCIONALIDADE DA LEI ESTADUAL QUE AUTORIZOU TAL DESIGNAÇÃO, O ATO POR ELE PRATICADO E VALIDO. RECURSO NÃO CONHECIDO. Relator: Min. Bilac Pinto, julgado em 07.06.1974, DJ 04.11.1974. Disponível em http://www.stf.jus.br. Acesso em 30.05.2010.

Supremo Tribunal Federal. RE 79682 (Tribunal Pleno) ACUMULAÇÃO DE CARGO HAVIDO COMO TECNICO, COM OUTRO, DE MAGISTERIO. INOCORRENCIA DE OFENSA A PRECEITO DA CONSTITUIÇÃO OU DE LEI FEDERAL. DISSIDIO JURISPRUDENCIAL NÃO DEMONSTRADO. RECURSO EXTRAORDINÁRIO NÃO CONHECIDO. Relator: Min. Moreira Alves, julgado em 13.05.1976, DJ 01.04.1977. Disponível em http://www.stf.jus.br. Acesso em 30.05.2010.

MAGISTRADO. ${ }^{\circ}$ GARANTIA CONSTITUCIONAL DA IRREDUTIBILIDADE DE VENCIMENTO. A NOVA QUALIFICAÇÃO DO TEMPO DE SERVIÇO, ANOS DEPOIS DE AVERBADO E DE HAVER PRODUZIDO EFEITOS PECUNIARIOS EM FAVOR DO MAGISTRADO, MALFERE A GARANTIA CONSTITUCIONAL DA IRREDUTIBILIDADE DE VENCIMENTOS, QUE TORNA INTANGIVEL O DIREITO QUE JA NASCEU E NÃO PODE SER SUPRIMIDO SEM QUE SEJAM DIMINUIDAS AS PRERROGATIVAS QUE SUPORTAM O SEU CARGO. RECURSO CONHECIDO E 
PROVIDO. Relator: Min. Carlos Madeira, julgado em 15.04.1986, DJ 09.05. 1986. Disponível em http://www.stf.jus.br. Acesso em 30.05.2010.

Supremo Tribunal Federal. RE 122202 ( $2^{\mathrm{a}}$ Turma) RECURSO EXTRAORDINÁRIO. EFEITOS DA DECLARAÇÃO DE INCONSTITUCIONALIDADE EM TESE PELO SUPREMO TRIBUNAL FEDERAL. ALEGAÇÃO DE DIREITO ADQUIRIDO. Acórdão que prestigiou lei estadual a revelia da declaração de inconstitucionalidade desta ultima pelo Supremo. Subsistencia de pagamento de gratificação mesmo após a decisão erga omnes da corte. Jurisprudência do STF no sentido de que a retribuição declarada inconstitucional não e de ser devolvida no periodo de validade inquestionada da lei de origem - mas tampouco paga após a declaração de inconstitucionalidade. Recurso extraordinário provido em parte. Relator: Min. Francisco Rezek, julgado em 10.08.1993, DJ 08.04.1994. Disponível em http://www.stf.jus.br. Acesso em 30.05.2010.

Supremo Tribunal Federal. RE $147776 \quad\left(1^{\text {a }}\right.$ Turma $)$ Ministério Público: legitimação para promoção, no juízo cível, do ressarcimento do dano resultante de crime, pobre o titular do direito à reparação: C. Pr. Pen., art. 68, ainda constitucional (cf. RE 135328): processo de inconstitucionalização das leis. 1. A alternativa radical da jurisdição constitucional ortodoxa entre a constitucionalidade plena e a declaração de inconstitucionalidade ou revogação por inconstitucionalidade da lei com fulminante eficácia ex tunc faz abstração da evidência de que a implementação de uma nova ordem constitucional não é um fato instantâneo, mas um processo, no qual a possibilidade de realização da norma da Constituição - ainda quando teoricamente não se cuide de preceito de eficácia limitada - subordina-se muitas vezes a alterações da realidade fáctica que a viabilizem. 2. No contexto da Constituição de 1988, a atribuição anteriormente dada ao Ministério Público pelo art. $68 \mathrm{C}$. Pr. Penal - constituindo modalidade de assistência judiciária - deve reputar-se transferida para a Defensoria Pública: essa, porém, para esse fim, só se pode considerar existente, onde e quando organizada, de direito e de fato, nos moldes do art. 134 da própria Constituição e da lei complementar por ela ordenada: até que - na União ou em cada Estado considerado -, se implemente essa condição de viabilização da cogitada transferência constitucional de atribuições, o art. 68 C. Pr. Pen. será considerado ainda vigente: é o caso do Estado de São Paulo, como decidiu o plenário no RE 135328. Relator: Min. Sepúlveda Pertence, julgado em 19.05.1998, DJ 19.06.1998. Disponível em http://www.stf.jus.br. Acesso em 30.05.2010. 
Supremo Tribunal Federal. RE 197917 (Tribunal Pleno)

RECURSO EXTRAORDINÁRIO. MUNICÍPIOS. CÂMARA DE VEREADORES. COMPOSIÇÃO. AUTONOMIA MUNICIPAL. LIMITES CONSTITUCIONAIS. NÚMERO DE VEREADORES PROPORCIONAL À POPULAÇÃO. CF, ARTIGO 29, IV. APLICAÇÃO DE CRITÉRIO ARITMÉTICO RÍGIDO. INVOCAÇÃO DOS PRINCÍPIOS DA ISONOMIA E DA RAZOABILIDADE. INCOMPATIBILIDADE ENTRE A POPULAÇÃO E O NÚMERO DE VEREADORES. INCONSTITUCIONALIDADE, INCIDENTER TANTUM, DA NORMA MUNICIPAL. EFEITOS PARA O FUTURO. SITUAÇÃO EXCEPCIONAL. 1. O artigo 29, inciso IV da Constituição Federal, exige que o número de Vereadores seja proporcional à população dos Municípios, observados os limites mínimos e máximos fixados pelas alíneas a, b e c. 2. Deixar a critério do legislador municipal o estabelecimento da composição das Câmaras Municipais, com observância apenas dos limites máximos e mínimos do preceito (CF, artigo 29) é tornar sem sentido a previsão constitucional expressa da proporcionalidade. 3 . Situação real e contemporânea em que Municípios menos populosos têm mais Vereadores do que outros com um número de habitantes várias vezes maior. Casos em que a falta de um parâmetro matemático rígido que delimite a ação dos legislativos Municipais implica evidente afronta ao postulado da isonomia. 4. Princípio da razoabilidade. Restrição legislativa. A aprovação de norma municipal que estabelece a composição da Câmara de Vereadores sem observância da relação cogente de proporção com a respectiva população configura excesso do poder de legislar, não encontrando eco no sistema constitucional vigente. 5. Parâmetro aritmético que atende ao comando expresso na Constituição Federal, sem que a proporcionalidade reclamada traduza qualquer afronta aos demais princípios constitucionais e nem resulte formas estranhas e distantes da realidade dos Municípios brasileiros. Atendimento aos postulados da moralidade, impessoalidade e economicidade dos atos administrativos $(\mathrm{CF}$, artigo 37). 6. Fronteiras da autonomia municipal impostas pela própria Carta da República, que admite a proporcionalidade da representação política em face do número de habitantes. Orientação que se confirma e se reitera segundo o modelo de composição da Câmara dos Deputados e das Assembléias Legislativas (CF, artigos 27 e $\left.45, \quad \S \quad 1^{\circ}\right) . \quad 7$. Inconstitucionalidade, incidenter tantun, da lei local que fixou em 11 (onze) o número de Vereadores, dado que sua população de pouco mais de 2600 habitantes somente comporta 09 representantes. 8. Efeitos. Princípio da segurança jurídica. Situação excepcional em que a declaração de nulidade, com seus normais efeitos ex tunc, resultaria grave ameaça a todo o sistema legislativo vigente. Prevalência do interesse público para assegurar, em caráter de exceção, efeitos pro futuro à declaração incidental de inconstitucionalidade. Recurso extraordinário conhecido e em parte provido. Relator: Min. Maurício Corrêa, julgado em 06.06.2002, DJ 07.05.2004. Disponível em http://www.stf.jus.br. Acesso em 30.05.2010. 
Supremo Tribunal Federal. RE 212484 (Tribunal Pleno) CONSTITUCIONAL. TRIBUTÁRIO. IPI. ISENÇÃO INCIDENTE SOBRE INSUMOS. DIREITO DE CRÉDITO. PRINCÍPIO DA NÃO CUMULATIVIDADE. OFENSA NÃO CARACTERIZADA. Não ocorre ofensa à $\mathrm{CF}$ (art. $153, \S 3^{\circ}$, II) quando o contribuinte do IPI credita-se do valor do tributo incidente sobre insumos adquiridos sob o regime de isenção. Recurso não conhecido. Relator: Min. Ilmar Galvão, Relator p/ Acórdão: Min. Nelson Jobim, julgado em 05.03.1998, DJ 27.11.1998. Disponível em http://www.stf.jus.br. Acesso em 30.05.2010.

. Supremo Tribunal Federal. RE 350446 (Tribunal Pleno) CONSTITUCIONAL. TRIBUTÁRIO. IPI. CREDITAMENTO. INSUMOS ISENTOS, SUJEITOS À ALÍQUOTA ZERO. Se o contribuinte do IPI pode creditar o valor dos insumos adquiridos sob o regime de isenção, inexiste razão para deixar de reconhecer-lhe o mesmo direito na aquisição de insumos favorecidos pela alíquota zero, pois nada extrema, na prática, as referidas figuras desonerativas, notadamente quando se trata de aplicar o princípio da não-cumulatividade. A isenção e a alíquota zero em um dos elos da cadeia produtiva desapareceriam quando da operação subseqüente, se não admitido o crédito. Recurso não conhecido. Relator: Min Nelson Jobim, julgado em 18.12.2002, DJ 06.06.2003. Disponível em http://www.stf.jus.br. Acesso em 30.05.2010.

. Supremo Tribunal Federal. RE 353657 (Tribunal Pleno) IPI

- INSUMO - ALÍQUOTA ZERO - AUSÊNCIA DE DIREITO AO CREDITAMENTO. Conforme disposto no inciso II do $\S 3^{\circ}$ do artigo 153 da Constituição Federal, observa-se o princípio da não-cumulatividade compensando-se o que for devido em cada operação com o montante cobrado nas anteriores, ante o que não se pode cogitar de direito a crédito quando o insumo entra na indústria considerada a alíquota zero. IPI INSUMO - ALÍQUOTA ZERO - CREDITAMENTO - INEXISTÊNCIA DO DIREITO - EFICÁCIA. Descabe, em face do texto constitucional regedor do Imposto sobre Produtos Industrializados e do sistema jurisdicional brasileiro, a modulação de efeitos do pronunciamento do Supremo, com isso sendo emprestada à Carta da República a maior eficácia possível, consagrando-se o princípio da segurança jurídica. Relator: Min. Marco Aurélio, julgado em 25.06.2007, DJe-041 DIVULG 06.03.2008 PUBLIC 07.03.2008. Disponível em http://www.stf.jus.br. Acesso em 30.05.2010. 
Supremo Tribunal Federal. RE 377457 (Tribunal Pleno) Contribuição social sobre o faturamento - COFINS (CF, art. 195, I). 2. Revogação pelo art. 56 da Lei 9.430/96 da isenção concedida às sociedades civis de profissão regulamentada pelo art. $6^{\circ}$, II, da Lei Complementar 70/91. Legitimidade. 3. Inexistência de relação hierárquica entre lei ordinária e lei complementar. Questão exclusivamente constitucional, relacionada à distribuição material entre as espécies legais. Precedentes. 4. A LC 70/91 é apenas formalmente complementar, mas materialmente ordinária, com relação aos dispositivos concernentes à contribuição social por ela instituída. ADC 1, Rel. Moreira Alves, RTJ 156/721. 5. Recurso extraordinário conhecido mas negado provimento. Relator: Min. Gilmar Mendes, julgado em 17.09.2008, DJe-241 DIVULG 18.12.2008 PUBLIC 19.12.2008. Disponível em http://www.stf.jus.br. Acesso em 30.05.2010.

Supremo Tribunal Federal. RE 430421 AgR (1 ${ }^{a}$ Turma) RECURSO. Extraordinário. Inadmissibilidade. IPTU. Progressividade. Lei municipal anterior à EC 29/00. Inconstitucionalidade. Súmula 668. Agravo regimental não provido. "É inconstitucional a lei municipal que tenha estabelecido, antes da Emenda Constitucional 29/2000, alíquotas progressivas para o IPTU, salvo se destinada a assegurar o cumprimento da função social da propriedade urbana". 2. RECURSO. Extraordinário. Lei Municipal. Declaração de inconstitucionalidade. Controle difuso. Efeito ex nunc. Inadmissibilidade. Não se aplica o efeito ex nunc à declaração de inconstitucionalidade em processo de controle difuso. 3. RECURSO. Agravo. Regimental. Jurisprudência assentada sobre a matéria. Caráter meramente abusivo. Litigância de má-fé. Imposição de multa. Aplicação do art. 557, § $2^{\circ}$, cc. arts. 14, II e III, e 17, VII, do CPC. Quando abusiva a interposição de agravo, manifestamente inadmissível ou infundado, deve o Tribunal condenar o agravante a pagar multa ao agravado. Relator: Min. Cezar Peluso, julgado em 30.11.2004, DJ 04.02.2005. Disponível em http://www.stf.jus.br. Acesso em 30.05.2010.

Supremo Tribunal Federal. RE 556664 (Tribunal Pleno) PRESCRIÇÃO E DECADÊNCIA TRIBUTÁRIAS. MATÉRIAS RESERVADAS A LEI COMPLEMENTAR. DISCIPLINA NO CÓDIGO TRIBUTÁRIO NACIONAL. NATUREZA TRIBUTÁRIA DAS CONTRIBUIÇÕES PARA A SEGURIDADE SOCIAL. INCONSTITUCIONALIDADE DOS ARTS. 45 E 46 DA LEI 8.212/91 E DO PARÁGRAFO ÚNICO DO ART. 5 DO DECRETO-LEI 1.569/77. RECURSO EXTRAORDINÁRIO NÃO PROVIDO. MODULAÇÃO DOS EFEITOS DA DECLARAÇÃO DE INCONSTITUCIONALIDADE. I. PRESCRIÇÃO E DECADÊNCIA TRIBUTÁRIAS. RESERVA DE LEI COMPLEMENTAR. As normas relativas à prescrição e à decadência tributárias têm natureza de normas gerais de direito tributário, cuja 
disciplina é reservada a lei complementar, tanto sob a Constituição pretérita (art. 18, § 1 10 da CF de 1967/69) quanto sob a Constituição atual (art. 146, b, III, da CF de 1988). Interpretação que preserva a força normativa da Constituição, que prevê disciplina homogênea, em âmbito nacional, da prescrição, decadência, obrigação e crédito tributários. Permitir regulação distinta sobre esses temas, pelos diversos entes da federação, implicaria prejuízo à vedação de tratamento desigual entre contribuintes em situação equivalente e à segurança jurídica. II. DISCIPLINA PREVISTA NO CÓDIGO TRIBUTÁRIO NACIONAL. O Código Tributário Nacional (Lei 5.172/1966), promulgado como lei ordinária e recebido como lei complementar pelas Constituições de 1967/69 e 1988, disciplina a prescrição e a decadência tributárias. III. NATUREZA TRIBUTÁRIA DAS CONTRIBUIÇÕES. As contribuições, inclusive as previdenciárias, têm natureza tributária e se submetem ao regime jurídico-tributário previsto na Constituição. Interpretação do art. 149 da CF de 1988. Precedentes. IV. RECURSO EXTRAORDINÁRIO NÃO PROVIDO. Inconstitucionalidade dos arts. 45 e 46 da Lei 8.212/91, por violação do art. 146, III, b, da Constituição de 1988 , e do parágrafo ú nico do art. $5^{\circ}$ do Decreto-lei 1.569/77, em face do $\S 1^{\circ}$ do art. 18 da Constituição de 1967/69. V. MODULAÇÃO DOS EFEITOS DA DECISÃO. SEGURANÇA JURÍDICA. São legítimos os recolhimentos efetuados nos prazos previstos nos arts. 45 e 46 da Lei 8.212/91 e não impugnados antes da data de conclusão deste julgamento. Relator: Min. Gilmar Mendes, julgado em 12.06.2008, DJe-216 DIVULG 13.11.2008 PUBLIC 14.11.2008. Disponível em http://www.stf.jus.br. Acesso em 30.05.2010.

Supremo Tribunal Federal. RE 559943 (Tribunal Pleno) DIREITO TRIBUTÁRIO. CONSTITUCIONALIDADE FORMAL DOS ARTIGOS 45 E 46 DA LEI N. 8.212/1991. ARTIGO 146, INCISO III, ALÍNEA B, DA CONSTITUIÇÃO DA REPÚBLICA. PRESCRIÇÃO E DECADÊNCIA TRIBUTÁRIAS. MATÉRIA RESERVADA À LEI COMPLEMENTAR. ARTIGOS 173 E 174 DO CÓDIGO TRIBUTÁRIO NACIONAL. RECURSO EXTRAORDINÁRIO AO QUAL SE NEGA PROVIMENTO. 1. A Constituição da República de 1988 reserva à lei complementar o estabelecimento de normas gerais em matéria de legislação tributária, especialmente sobre prescrição e decadência, nos termos do art. 146, inciso III, alínea b, in fine, da Constituição da República. Análise histórica da doutrina e da evolução do tema desde a Constituição de 1946. 2. Declaração de inconstitucionalidade dos artigos 45 e 46 da Lei n. 8.212/1991, por disporem sobre matéria reservada à lei complementar. 3 . Recepcionados pela Constituição da República de 1988 como disposições de lei complementar, subsistem os prazos prescricional e decadencial previstos nos artigos 173 e 174 do Código Tributário Nacional. 4. Declaração de inconstitucionalidade, com efeito ex nunc, salvo para as ações judiciais propostas até 11.6.2008, data em que o Supremo Tribunal 
Federal declarou a inconstitucionalidade dos artigos 45 e 46 da Lei n. 8.212/1991. 5. Recurso extraordinário ao qual se nega provimento. Relatora: Min.Cáren Lucia, julgado em 12.06.2008, DJe-182 DIVULG 25.09.2008 PUBLIC 26.09.2008. Disponível em http://www.stf.jus.br. Acesso em 30.05.2010.

Supremo Tribunal Federal. RE 560626 (Tribunal Pleno) PRESCRIÇÃO E DECADÊNCIA TRIBUTÁRIAS. MATÉRIAS RESERVADAS A LEI COMPLEMENTAR. DISCIPLINA NO CÓDIGO TRIBUTÁRIO NACIONAL. NATUREZA TRIBUTÁRIA DAS CONTRIBUIÇÕES PARA A SEGURIDADE SOCIAL. INCONSTITUCIONALIDADE DOS ARTS. 45 E 46 DA LEI 8.212/91 E DO PARÁGRAFO ÚNICO DO ART. $5^{\circ}$ DO DECRETO-LEI 1.569/77. RECURSO EXTRAORDINÁRIO NÃO PROVIDO. MODULAÇÃO DOS EFEITOS DA DECLARAÇÃO DE INCONSTITUCIONALIDADE. I. PRESCRIÇÃO E DECADÊNCIA TRIBUTÁRIAS. RESERVA DE LEI COMPLEMENTAR. As normas relativas à prescrição e à decadência tributárias têm natureza de normas gerais de direito tributário, cuja disciplina é reservada a lei complementar, tanto sob a Constituição pretérita (art. 18, § $1^{\circ}$, da CF de 1967/69) quanto sob a Constituição atual (art. 146, III, b, da CF de 1988). Interpretação que preserva a força normativa da Constituição, que prevê disciplina homogênea, em âmbito nacional, da prescrição, decadência, obrigação e crédito tributários. Permitir regulação distinta sobre esses temas, pelos diversos entes da federação, implicaria prejuízo à vedação de tratamento desigual entre contribuintes em situação equivalente e à segurança jurídica. II. DISCIPLINA PREVISTA NO CÓDIGO TRIBUTÁRIO NACIONAL. O Código Tributário Nacional (Lei 5.172/1966), promulgado como lei ordinária e recebido como lei complementar pelas Constituições de 1967/69 e 1988, disciplina a prescrição e a decadência tributárias. III. NATUREZA TRIBUTÁRIA DAS CONTRIBUIÇÕES. As contribuições, inclusive as previdenciárias, têm natureza tributária e se submetem ao regime jurídico-tributário previsto na Constituição. Interpretação do art. 149 da CF de 1988. Precedentes. IV. RECURSO EXTRAORDINÁRIO NÃO PROVIDO. Inconstitucionalidade dos arts. 45 e 46 da Lei 8.212/91, por violação do art. 146, III, b, da Constituição de 1988 , e do parágrafo ú nico do art. $5^{\circ}$ do Decreto-lei 1.569/77, em face do $\S 1^{\circ}$ do art. 18 da Constituição de 1967/69. V. MODULAÇÃO DOS EFEITOS DA DECISÃO. SEGURANÇA JURÍDICA. São legítimos os recolhimentos efetuados nos prazos previstos nos arts. 45 e 46 da Lei 8.212/91 e não impugnados antes da data de conclusão deste julgamento. Relator: Min. Gilmar Mendes, julgado em 12.06.2008, DJe-232 DIVULG 04.12.2008 PUBLIC 05.12.2008. Disponível em http://www.stf.jus.br. Acesso em 30.05.2010. 